\title{
ANNETTE HOLST-HANSSON
}

ON A JOURNEY FOR SURVIVAL: Everyday life during radiation therapy from the perspectives of women with breast cancer and their families
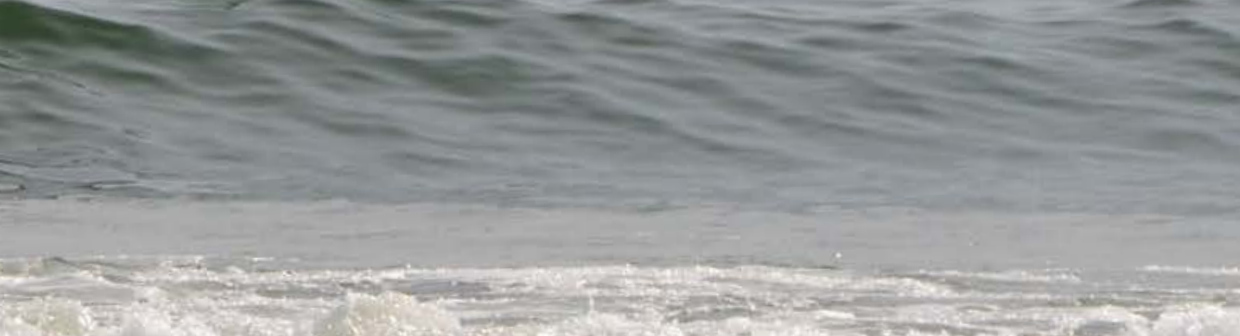

ON A JOURNEY FOR SURVIVAL: EVERYDAY LIFE DURING RADIATION THERAPY FROM THE PERSPECTIVES OF WOMEN WITH BREAST CANCER AND THEIR FAMILIES 
Malmö University, Faculty of Health and Society Department of Care Science Doctoral dissertation 2018:8

(C) Annette Holst-Hansson 2018 Cover: Annette Holst-Hansson ISBN 978-9I-7 IO4-920-9 (print) ISBN 978-9I-7 I04-92 I-6 (pdf)

Holmbergs, Malmö 20I 8 


\section{ANNETTE HOLST-HANSSON ON A JOURNEY FOR SURVIVAL: EVERYDAY LIFE DURING RADIATION THERAPY FROM THE PERSPECTIVES OF WOMEN WITH BREAST CANCER AND THEIR FAMILIES}

Malmö University, 2018 Faculty of Health and Society 
This publication is also available at:

http://dspace.mah.se/handle/2043/25059 
To everyone who has believed in me

Vi människor är sociala varelser. Vi kommer till denna värld som ett resultat av andras handlingar. För vår överlevnad är vi ömsesidigt beroende av varandra. Vare sig vi vill eller inte finns det inte en enda stund $\mathrm{i}$ livet då vi inte drar nytta av sådant som andra har gjort eller gör. Det är därför knappast förvånande att det mesta av vår lycka uppstår i relationer med andra. Inte heller är det anmärkningsvärt om vår största glädje uppstår när vi motiveras av omsorg om andra. Men det är mera än så. Allt tyder på att altruistiska handlingar inte bara skapar lycka, utan att de också minskar vår upplevelse av lidande.

Vårt beteende mot andra blir automatiskt positivt när vi handlar av omsorg mot dem. Det är för att vi inte har plats för några misstankar när hjärtat är fyllt av kärlek. Det är som en inre dörr öppnas och låter oss komma ut.

Dalai Lama 



\section{CONTENTS}

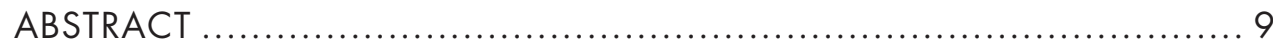

LIST OF PUBLICATIONS I-IV ............................................ 11

INTRODUCTION ..................................................... 13

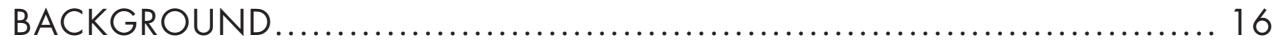

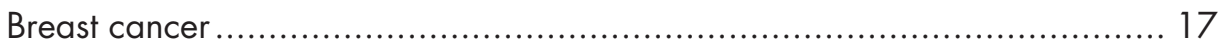

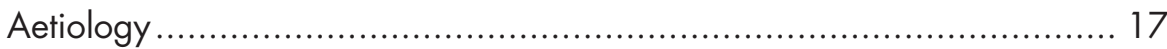

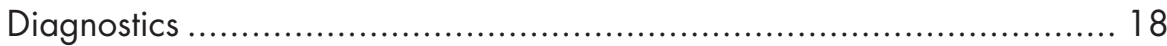

Women's experiences from the time of diagnosis to

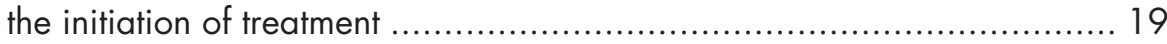

Treatment and women's experiences of the

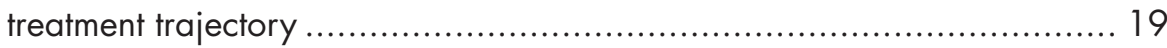

Women's experience of diagnosis and treatment related to age.

Women's experience of diagnosis and treatment

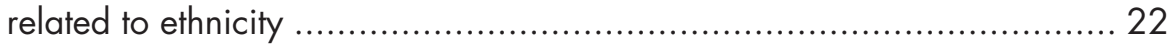

A family perspective .................................................................. 23

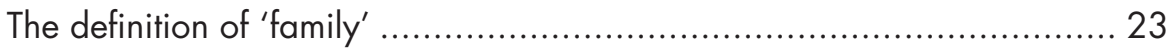

Breast cancer in a family member from the perspective

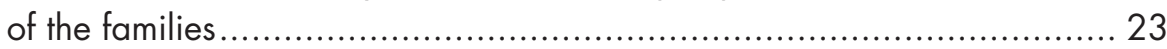

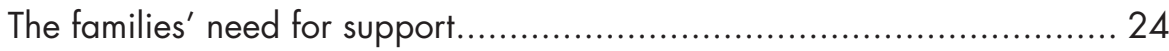

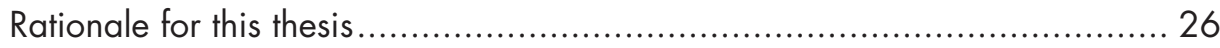

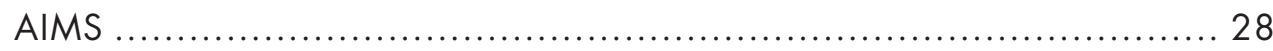

METHODS _.............................................................. 29

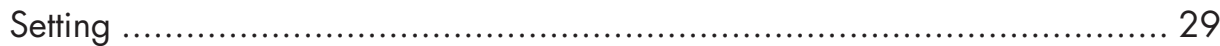

Participants................................................................... 31 


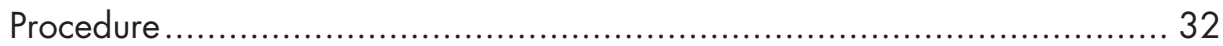

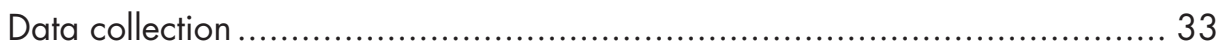

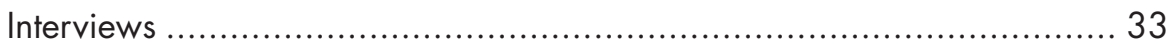

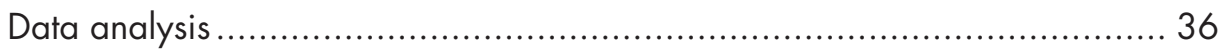

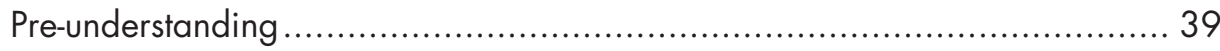

ETHICAL CONSIDERATIONS ............................................. 41

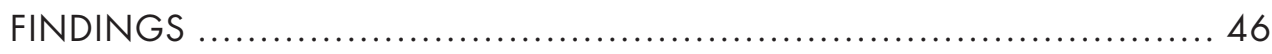

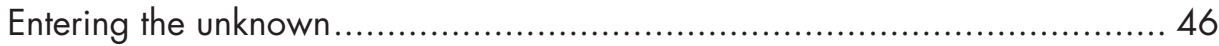

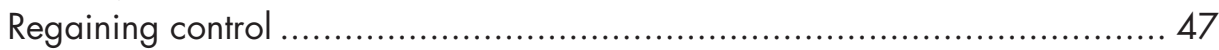

Balancing between hope and despair ............................................ 48

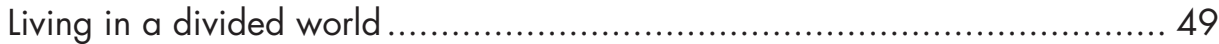

Needing support from the health care professionals................................ 51

METHODOLOGICAL CONSIDERATIONS ................................ 53

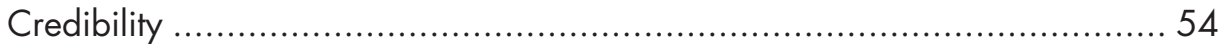

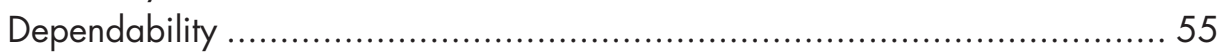

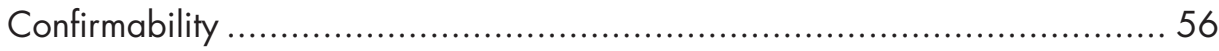

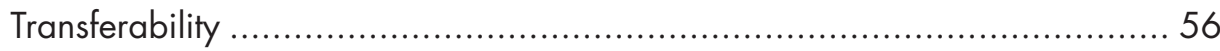

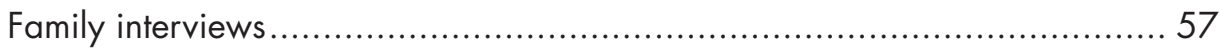

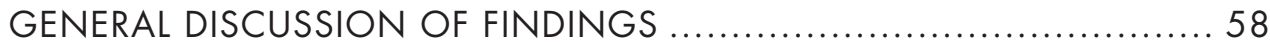

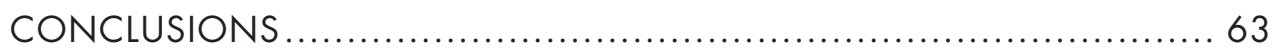

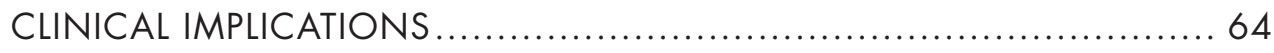

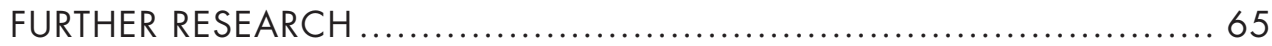

SAMMANFATTNING PÅ SVENSKA .......................................6 66

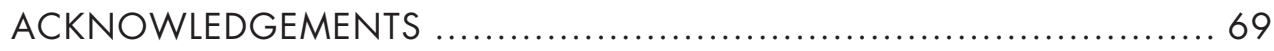

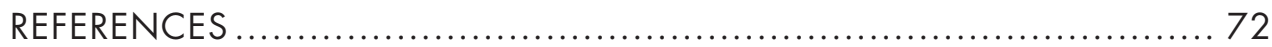

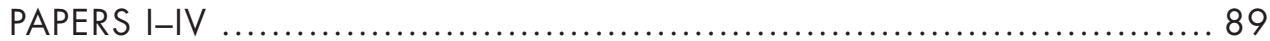




\section{ABSTRACT}

This thesis focuses on women diagnosed with breast cancer and their family members. Since a breast cancer diagnosis and its subsequent treatment are a strenuous experience not only for the woman afflicted but also for her family members, this thesis aimed to explore the experiences of everyday life during radiation therapy from the perspectives of the woman with breast cancer and her family, as well as exploring families' experiences of participating in short family health conversations (SFamHC).

All included studies were interview studies (Papers I, II, III \& IV), where 30 women (20 in Paper I and 10 in Paper II) with breast cancer, 19 family members including the women with breast cancer (Paper III) and 9 families (Paper IV) were interviewed. The data from the interviews was analysed using qualitative content analysis (Papers I \& II), a hermeneutical phenomenological method (Paper III) and thematic analysis (Paper IV).

The women's experiences of breathing adapted radiation therapy (BART) (Paper I) were identified in an overall theme, The breath of life, as the women experienced the breathing as a way to influence their treatment and thus their survival. The overall theme could be divided into one main category: Participating in one's treatment, for good or ill, with four subcategories: Knowing one has done something good, Getting an extra bonus healthwise, The experience of being in control and Being in a hightechnology environment.

Women born in Iraq and the former Yugoslavia, diagnosed with breast cancer and living in Sweden, experienced their everyday life during radiation therapy as a narrow and challenging treatment road to survival (Paper II). Their experiences were structured into three categories: Strategies for survival, Keeping up appearances and Staying in control. More focus should be on acknowledging the woman behind the diagnosis, regardless of her origin, in order to 
develop individualised support programmes to help women cope with everyday life during radiation therapy.

The families' lived experience when a family member is diagnosed with breast cancer (Paper III) was described as a challenging endeavour to regain an ordinary, safe life, hoping to reach a safe haven. The families felt that life as they knew it had disappeared and they were fumbling in the dark and pursuing balance by struggling to keep the family together and by maintaining a positive attitude. They were also struggling with guilt and inadequacy, due to their difficulties in communicating emotional distress and to feeling abandoned by the health care professionals.

Families' experiences of participating in short family health conversations (SFamHC) (Paper IV) were identified in four key themes: Bringing everything out in the open, Being confirmed as an individual and as a family, Gaining an unexpected insight and Timing and context matter.

The findings from this thesis can deepen the understanding of what living with breast cancer is like, from the perspectives of the women with breast cancer and their families, as well as increasing the understanding of their needs. Their experiences could be described as a journey for survival, a journey that starts at the time of diagnosis and that they are still partaking in when concluding their radiation therapy treatment. The journey for survival sends them off into the unknown, where they strive to regain control, balancing between hope and despair, experiencing their life as divided into an outer and inner world and needing support from each other as well as from health care professionals. A possible way to support the women and their family members could be to offer them participation in short family health conversations (SFamHC), since these conversations provide them with an opportunity to verbalise and share their feelings and thoughts. Those participants (Paper IV) who took part in SFamHC felt that their participation in the SFamHC helped them to move forward and beyond the breast cancer diagnosis. 


\section{LIST OF PUBLICATIONS I-IV}

This thesis is based on the following papers, referred to in the text by their Roman numbers. The published papers have been reprinted with permission from the publishers.

I. Holst-Hansson, A., Sjövall, K., Idvall, E. and Bolmsjö, I. (2013). The breath of life - Women's experiences of breathing adapted radiation therapy. European Journal of Oncology Nursing, 17, 354-359. Doi:10.1016/j.ejon.2012.10.003

II. Holst-Hansson, A., Idvall, E., Bolmsjö, I. and Wennick, A. (2018). The narrow treatment road to survival: Everyday life perspectives of women with breast cancer from Iraq and the former Yugoslavia undergoing radiation therapy in Sweden. European Journal of Cancer Care, 27(2), 1-9. Doi:10.1111/ecc.12825

III. Holst-Hansson, A., Idvall, E., Bolmsjö, I. and Wennick, A. (2017). Hoping to reach a safe haven - Swedish families' lived experience when a family member is diagnosed with breast cancer. European Journal of Oncology Nursing, 31, 52-58. Doi:10.1016/j.ejon.2017.10.003

IV. Holst-Hansson, A., Vejzovic, V., Idvall, E., Bolmsjö, I. and Wennick, A. The experiences of participating in Short Family Health Conversations from the perspective of families where a family member is diagnosed with breast cancer. In manuscript.

Contributions to the publications listed above: $\mathrm{AHH}$ initiated the design, planned the studies (I, II, III \& IV), collected the data (Paper I, II \& III), led the short family health conversations (SFamHC) (Paper IV), performed the analysis and wrote the papers (I, II, III \& IV) with the support of the coauthors. 


\section{INTRODUCTION}

Being a woman and receiving a breast cancer diagnosis is described as a lifechanging event that causes disruption in everyday life (Campbell-Enns \& Woodgate, 2017). The diagnosis throws the afflicted woman into a state of uncertainty, making her experience feelings of distress and fear of recurrence but also hope of recovery. She might furthermore experience significant role changes, as well as issues pertaining to an altered body image (ibid.). There is a great deal of research showing that the diagnosis and its subsequent treatment afflict the women both physically and psychologically (Browall et al., 2008; Courtier et al., 2013; DiSipio et al., 2013; Halkett et al., 2008; Lewis et al., 2014; Lim et al., 2011).

Treatment regimens are constantly developed and improved in order to increase survival rates. The demands of the treatment may take a heavy emotional and practical toll on both the afflicted woman and her family in their everyday life (Dunn et al., 2012). With the aim of further increasing the breast cancer-specific survival rates and reducing the side effects, a breathing adapted radiation therapy (BART) technique was developed in the USA and this technique was introduced in Sweden in 2007. Although the technique is well explored with regard to its efficiency and accuracy, there seems to be limited knowledge of how women experience BART.

Like many other European countries, Sweden has been affected by extensive global migration and has become a multicultural society (United Nations High Commissioner for Refugees, 2018; Statistics Sweden, 2018). In a multicultural society, the frequency of contact with immigrant women with breast cancer will increase, along with the need for more knowledge of their situation and experiences. Research has suggested that the impact of being diagnosed with breast cancer may vary based on the ethnic origin of the women (Ashing-Giwa \& Lim, 2011; Kwan et al., 2010; Luckett et al., 2011; Vrinten et al., 2016). 
Despite increased globalisation, research elucidating the experience of breast cancer and radiation therapy among immigrant women from the Balkans and countries in the Middle East is still lacking.

Family members may be affected by the range of emotions that occur in the woman diagnosed with breast cancer as well as by the new life situation that follows, especially since breast cancer is seen as a potentially life-threatening illness (Coyne et al., 2012; Northouse et al., 2012; Robbins et al., 2013; Schubart et al., 2014). There is a growing interest in how the family experiences the woman's breast cancer diagnosis, although few studies elucidating family experience have included both the patient and her family (Robbins et al., 2013). Despite the strain a breast cancer diagnosis in the family may put on the individual family member, little research has specifically addressed families' experiences from a joint perspective, including the affected woman and her family members.

Although there is an increasing awareness of the importance of assessing and acknowledging the needs of the family when they face a major shift, like adapting to a family illness, this is often addressed both informally and unsystematically by health professionals (dos Santos Ribeiro Silva et al., 2013). The families' experiences of a changed and stressful everyday life following a breast cancer diagnosis (Northouse et al., 2012) suggest that more empirical studies are needed in the context of families where a family member is diagnosed with breast cancer. This is further emphasised by the number of women and families afflicted by breast cancer and their unmet need of support (Coyne et al., 2012; John et al., 2013). Moreover, the positive impact previous research has shown in families participating in family health conversations (FamHC) in other contexts, for example, when a family member experienced chronic illness, cardiac and ischemic illness, depression or childhood cancer (Bell, 2015; Benzein et al., 2015; Östlund \& Persson, 2014), points to the importance of empirical studies involving the whole family.

Since the diagnosis and its subsequent treatment are reported as a strenuous experience for both the woman afflicted and her family members, this thesis aimed to explore the experiences of everyday life during radiation therapy from the perspectives of the woman with breast cancer and her family and to explore the families' experiences of participating in Short Family Health Conversations (SFamHC). This approach includes the family's life situation, that is, their experiences, emotions and needs as individuals and as a family, but also their interactions, when a family member is diagnosed with breast cancer. By exploring the perspectives of women and their families, knowledge can be 
attained which may be used to develop information and support in order to improve the well-being in everyday life for both the woman and her family. 


\section{BACKGROUND}

Women with breast cancer have described how navigating a breast cancer diagnosis and treatment trajectory and then going on to being a cancer survivor is a traumatic experience that is complicated by an emotional turmoil (Williams \& Jeanetta, 2015). For many women, the diagnosis and treatment of breast cancer impact not only the physiological and psychological but also the social aspects of everyday life, from the time of diagnosis and throughout the treatment trajectory as well as during survivorship.

Everyday life can be seen as a sociological metaphor for life itself; it is the life we live every day, and it comprises all of daily life, that is, the family, the home, the work and all other situations (Bech-Jørgensen, 1994, 2001). Further, everyday life is created when humans deal with the circumstances and conditions of life, which they do in different ways but always in their particular cultural and social context (ibid.). Being diagnosed with a life-threatening illness like breast cancer can result in one's very existence being experienced as threatened (Frankl, 1996) and this might cause existential suffering. From a holistic perspective, suffering can be defined as loss of meaning, alienation, hopelessness and helplessness, and it can be dynamic as well as negative and pervade a person's entire being (Best et al., 2015). A serious illness, like breast cancer, can be viewed as a crucial existential crossroads that disrupts values, thoughts and feelings (Jaspers as cited in Benktson, 1977), and this is what befalls the woman diagnosed with breast cancer and her family. In order for the woman and her family to grow and manage these disruptions and obstacles they have to face them, and thereby see life as it is, as a new life situation that should be embraced, since life is an ongoing motion (Benktson, 1977).

Being diagnosed with breast cancer has been shown to evoke a state of shock, fear and disbelief, thus creating not only a psychological crisis but an existential one as well (Caplan, 2011; Kernan \& Lepore, 2009; Weisman \& 
Worden, 1977). Further, the psychosocial impact of the diagnosis and its treatment may include distress associated with, among other things, fatigue, mood, sexual and reproductive issues, self-image, spiritual challenges, relationships with others, existential thoughts and issues, uncertainty and fear of recurrence (Caldeira et al., 2016; Denieffe \& Gooney, 2011; Glaser et al., 2013; Lebel et al., 2013; Segrin \& Badger, 2014; Snöbohm et al., 2010). The associated fear of recurrence is a consistent psychological stress throughout the treatment trajectory and beyond, even in long-term survivors (Koch et al., 2014; Mehnert et al., 2009).

Although breast cancer is associated with great distress, most women adjust well to the diagnosis, especially if their need of support from health care professionals as well as from their family and other people in their vicinity, is met (Campbell-Enns \& Woodgate, 2017). Understanding the women's experiences is of great importance, since a negative psychosocial impact might accompany the women along the treatment trajectory with long-term consequences for their quality of life (Linden et al., 2012; Waldrop et al., 2011; Zebrack et al., 2008).

\section{Breast cancer}

\section{Aetiology}

The breast cancer incidence has almost tripled during the past 30 years (Forouzanfar et al., 2011) and it is the most common cancer among women worldwide with 2.4 million women diagnosed in 2015 (Ferlay et al., 2015; Fitzmaurice et al., 2017). The highest incidence is seen in North America and other developed regions, like Western Europe, while Asia and Africa have the lowest incidence. The prevalence shows a sharp age gradient, with about a quarter of all breast cancer cases occurring before 50 years of age, and less than five per cent before the age of 35 (Gatta et al., 2013), whereas the highest incidence is seen in the ages 50-69 years (Ferlay et al., 2015; The National Board of Health and Welfare, 2015a). Breast cancer development encompasses an intricate interplay between factors such as family history of the illness, increasing age, alcohol, hormone replacement therapy and reproductive factors such as early age at menarche, late menopause and late age at first full-term pregnancy, while physical activity and breast feeding might decrease the risk (World Cancer Research Fund International, 2017). 
Although the average five-year survival rates have improved during the last decades, breast cancer claims the lives of more European women than any other cancer (Ferlay et al., 2015). With increasing incidence, improvements in treatment methods and a growing number of survivors, more women are living a prolonged time with breast cancer (Ferlay et al., 2015; The National Board of Health and Welfare, 2015a).

In Sweden, approximately 9,400 women are diagnosed annually and approximately 30 per cent of all female cancer is breast cancer (The National Board of Health and Welfare, 2015a). Today the relative five- and ten-year survival rates in Sweden have improved to 90 and 80 per cent, respectively (ibid.), compared to 72 and 58 per cent during the 1970s (Holmberg et al., 2001). Approximately 104,000 women with breast cancer - newly diagnosed, cured or with a relapse - were living in Sweden in 2014 (Engholm et al., 2016).

\section{Diagnostics}

In Sweden, most breast tumours are detected at routine mammography screening, although some women detect a palpable lump on their own and seek diagnostic testing (The National Board of Health and Welfare, 2015b). Mammography screening involves an x-ray examination of the breasts to detect tumours at an early stage before symptoms are exhibited (ibid.). The motivation for the screening programme is that mortality decreases by 20-25 per cent (Marmot et al., 2013). The diagnosis is based on clinical examination in combination with imaging, and confirmed by pathological assessment (Senkus et al., 2015). Imaging includes bilateral mammography and ultrasound of the breast and regional lymph nodes. Pathological Anatomical Diagnosis (PAD) should be established on a core needle biopsy and pathological examination of the primary tumour as well as cytology and histology of axillary nodes if involvement is suspected (ibid.). The woman is often referred to a multidisciplinary breast team and in that first appointment she usually receives a preliminary diagnosis, but also a date for surgery and a date for a surgical follow-up appointment where the complete PAD is revealed (RCC, 2018). 
Women's experiences from the time of diagnosis to the initiation of treatment

The initial finding of change in breast tissue tends to be distressing even if a malignancy is not found (Bolejko et al., 2013; Lou et al., 2015). The subsequent process of breast screening, and then awaiting the result (ibid.) or surgery, is experienced as emotionally distressing (Denieffe et al., 2014). Further, it is evident that women at diagnosis experience a turmoil of emotions including shock, fear, anxiety, distress and anger (Beatty et al., 2008; Lim et al., 2011). This is a time of great uncertainty for the woman, and also the start of a long treatment trajectory that can range from three to eight months.

\section{Treatment and women's experiences of the treatment trajectory}

Surgery is often only the start of modern breast cancer treatment and performed within one or two weeks after diagnosis (RCC, 2018). This stage includes removal of cancerous tissue by breast conserving surgery (BCS), also known as partial mastectomy or lumpectomy, or mastectomy, with or without axillary nodal clearance. The physical effects of the surgery are initially pain or discomfort, reduction of movement and swelling to the breast area, and those physical effects may continue in the shape of discomfort, reduction of movement, pain, numbness and lymphedema (Beatty et al., 2008; DiSipio et al., 2013). The psychological strains in connection with surgery have been expressed as anxiety (Lim et al., 2011), fear and uncertainty (Remmers et al., 2010).

For many women, the next phase of treatment may be the chemotherapy, which is often administered in an outpatient oncology setting. Chemotherapy may vary in length of time and combination, although the most common regimens for adjuvant breast cancer are usually prescribed for a course of 18 weeks: six treatments with three-week intervals. Chemotherapy may be associated with a decrease in overall health-related quality of life, and in physical and role functioning, and with a changed body image, as well as fatigue, dyspnea, pain, nausea/vomiting, systemic therapy side effects (Browall et al., 2008; Zhang et al., 2018) and anxiety (Browall et al., 2008; Lim et al., 2011). For younger women, treatment-induced menopause adds to the effectiveness of chemotherapy in the case of a hormonally receptive positive tumour, but may also give a range of severity of symptoms like hot flushes, and libido and vaginal changes, which may influence the women's well-being (RCC, 2018). The endocrine treatment (maintenance treatment) is prescribed for at least five 
years and is often initiated in connection with the start of radiation therapy (RCC, 2018).

For some women, radiation therapy is given immediately following surgery, but if they receive chemotherapy treatment it is given after the chemotherapy. The radiation therapy is seen as the last stage in the active treatment, which will take place over an intensive period sometimes lasting for over half a year. Most radiation treatments are given as a supplement after surgery, to reduce the risk of local recurrence, but breast cancer-specific survival rates also improve after irradiation following both breast-conserving surgery and mastectomy (Early Breast Cancer Trialists' Collaborative Group [EBCTCG], 2011, 2014). Radiation therapy is given postoperatively to more than half of all women with breast cancer (RCC, 2018). It is given once a day, five days a week, with a total treatment period ranging from 15 to 33 days, although the most common treatment regimen is 15 or 25 days (ibid.).

Women receiving radiation therapy develop skin reactions within the treated area ranging from skin discoloration to moist desquamation (Salvo et al., 2010); they may also experience pain, emotional distress and impaired body image and everyday functioning (Lim et al., 2011; Schnur et al., 2011a, $2011 \mathrm{~b}$ ). Another side effect of radiation therapy is the build-up of fatigue, especially towards the end of treatment, and fatigue often compounds the previous tiredness induced by chemotherapy (Courtier et al., 2013; Lipsett et al., 2017). There is some evidence that anxiety before the radiation treatment is associated with higher levels of fatigue during radiation therapy (Courtier et al., 2013), and previous research has shown that many women diagnosed with breast cancer experience anxiety before, during and after their radiation therapy treatment (Halkett et al., 2008; Halkett et al., 2012; Lewis et al., 2014; Schnur et al., 2009).

The precision and accuracy in radiation therapy technology has developed extensively over the years (Njeh, 2008). Yet, research has shown an increased risk of cardiovascular-related morbidity and mortality in women who have received radiation therapy for breast cancer on the left side (Darby et al., 2013). A new radiation therapy technology, breathing adapted radiation therapy (BART), which uses the movement of the chest when the woman breathes to its advantage (Korreman et al., 2008), was introduced to reduce the risk of cardiac events (Nemoto et al., 2009). In Sweden, BART was first introduced in a regional hospital in the south of Sweden in 2007, and it is now available in almost the whole country (RCC, 2018). 
BART requires an active participation of the woman during treatment, and she is trained to breathe deeply, regularly and reproducibly, and is guided by a recorded voice during treatment (Korreman et al., 2008). When the woman takes deep breaths the chest rises further away from the heart. The radiation is given only when the woman is in the right respiratory phase, in other words, when the chest is as far from the heart as possible (Korreman et al., 2008; Nemoto et al., 2009). There is a need to know how an active participation in radiation therapy, through breathing, is experienced by the women, especially since it is evident that women diagnosed with breast cancer experience increased levels of anxiety in connection with their radiation therapy treatment (Halkett et al., 2012; Lewis et al., 2014; Schnur et al., 2009).

\section{Women's experience of diagnosis and treatment related to age}

It has been suggested that the experience of women with breast cancer may be different depending on the woman's age. Some evidence shows that younger women are more likely to struggle with emotional and social concerns, pertaining to body image, sexual functioning, fertility-related issues, caring for children, family roles and relations as well as career issues (Ahmad et al., 2015; Paterson et al., 2016; Peate et al., 2009; Raque-Bogdan et al., 2015; Ruddy et al., 2014; Stinesen Kollberg et al., 2013). Research has emphasised women's need for support when it comes to telling their children of their cancer diagnosis (Asbury et al., 2014; Semple \& McCance, 2010; Stinesen Kollberg et al., 2013), as the overarching aim of a mother is to protect her children (Fisher \& O'Connor, 2012). The findings of research concerning the influence of age on the experiences of women diagnosed with breast cancer are somewhat inconclusive, as there is research that states that older women experience more physical health concerns and poorer health-related quality of life than younger women (Mor et al., 1994; Sammarco, 2003; van Ee et al., 2017). Further, a systematic review showed that younger and older women, regardless of age, share multiple psychosocial experiences and work hard to deal with what cancer imposes on them, as well as caring for their loved ones and struggling to find their way beyond the breast cancer (Campbell-Enns \& Woodgate, 2017). 


\section{Women's experience of diagnosis and treatment related to ethnicity}

The impact of being diagnosed with breast cancer has also been suggested to vary based on the ethnic origin of the women (Ashing-Giwa \& Lim, 2011). There are 60 million people who are displaced or living in refugee-like situations globally (United Nations High Commissioner for Refugees, 2018), which is a situation that has not been seen since the Second World War. Many women from Iraq, Syria, the former Yugoslavia (i.e. Bosnia-Herzegovina, Croatia, Macedonia, Montenegro, Serbia and Slovenia) and Afghanistan are now living in Europe and the USA due to war and persecution, which suggests that they are affected by socio-psychological stress (Al-Baldawi, 2002). Hence, being diagnosed with breast cancer can be experienced as an additional stressor that requires further adaptation for a woman who is simultaneously situated in an acculturation process due to migration (Berry, 2005).

Thus, women from ethnic minorities diagnosed with breast cancer report lower rates of emotional well-being and quality of life (QoL), higher rates of anxiety and fear of recurrence (Ashing-Giwa \& Lim, 2011; Kwan et al., 2010; Luckett et al., 2011; Patel-Kerai et al., 2017; Vrinten et al., 2016) and more symptoms of depression (Christensen et al., 2009; Patel-Kerai et al., 2017) than non-minority women and even more so in less acculturated women (Vrinten et al., 2016). Research performed in the USA demonstrated that poorer health-related quality of life in a multi-ethnic population of women diagnosed with breast cancer was associated with ethnicity, but also with lower socio-economic status and high socio-ecological stress, which suggests that the links between a cancer diagnosis, ethnicity and quality of life are multifaceted (Ashing-Giwa \& Lim, 2009). Further, research examining predictors of the quality of life (QoL) of breast cancer survivors over time found that ethnicity was not associated with any of the QoL measures, with the exception of faith and assurance (Levine et al., 2017). Ashing-Giwa and Lim (2011) also found that fear of cancer progression and recurrence, as well as feelings of uncertainty and sadness, were experienced as the most difficult concerns across all breast cancer survivors regardless of ethnicity. 


\section{A family perspective}

\section{The definition of 'family'}

A family can be described as a system in which the family members interact mutually; they represent elements in relationship to each other and when in balance this system assures the members of predictability, security and feelings of connectedness. There are many definitions of the concept of family, where the concept focuses on the relationships, the interaction and the reciprocity in the family (Burgess \& Locke, 1953; Craft \& Willadsen, 1992; HarmonHanson et al., 2005; Rowe Kaakinen, 2015; Whall, 1986; Wright et al., 2002). Wright and Leahey (2013) have an open and inclusive definition of a family, namely: 'the family is who they say they are' (p. 55). Hence, a family is constituted by those who feel that they belong to the family, regardless of how their relations are viewed from the outside. In other words, the individual identifies and defines whom they specifically think belong to their family. Wright and Leahey's (2013) open definition of the concept of family makes it possible to remain inclusive with regard to an individual's own choice of the structure of a family, so that a family can be a same-sex or single-parent family as well as encompassing significant others like friends and other relatives. This means that a family is based on interactions and emotional closeness and not limited to legal settlements or blood ties.

\section{Breast cancer in a family member from the perspective of the families}

When a family member goes through challenges like a breast cancer diagnosis and its subsequent treatment, it may affect the whole family. Living as a family in the new life situation where a family member is diagnosed with breast cancer could put a strain on both the individual and the family as a unit. However, only a limited number of studies have a family focus when exploring the experiences of living with breast cancer. Instead, previous research has explored family experience focusing on the spouse's experience (Lewis et al., 2008; Lopez et al., 2012), the child's experience (Edwards et al., 2008; Huang et al., 2014) or a couple's dyadic experience (Belcher et al., 2011; Robbins et al., 2014; Sprung et al., 2011). Research has shown that spouses and other close adult relatives experience increased levels of anxiety and depression (Fletcher et al., 2010; Lewis et al., 2008; Schmid-Büchi et al., 2011), as well as reduced quality of life (Bigatti et al., 2011; Duggleby et al., 2014; Wagner et al., 2006; Wagner et al., 2011). The spouses also express a perceived lack of 
support and information from health care professionals (Northouse et al., 2005). Further, a diagnosis of breast cancer can have a profound impact on the couple's relationship, leading to severe couple distress (Sprung et al., 2011) resulting in increased psychological distress and worse quality of life for the individuals (Drabe et al., 2013), but there is also some evidence of couples experiencing increased closeness (Ahmad et al., 2017; Drabe et al., 2013; Kraemer et al., 2011).

Other researchers have elucidated children's experiences of parental cancer, finding these children affected by distress and emotional and behavioural problems, as well as having unmet informational and supportive needs (Huang et al., 2014; Vannatta et al., 2008) when trying to adapt to and normalise their situation (Clemmens, 2009). Better adjustments to parental cancer were shown to be associated with better family functioning, while lower emotional states in parents were shown to be in concordance with worse adjustments of the children (Krattenmacher et al., 2012; Vannatta, 2010).

Radiation therapy causes worry and anxiety in patients, but there is also evidence that it affects the persons close to the patient (Dunn et al., 2012). Being young, a woman, belonging to an ethnic minority, and having children at home, are factors that increase the likelihood of experiencing elevated levels of anxiety and depression at the start of and during the radiotherapy. Furthermore, if these factors characterise the patient, then the person most involved in her care (i.e. the family caregiver) is also at risk of experiencing an increase in anxiety and depression (ibid.).

\section{The families' need for support}

The families experience challenges and multifaceted needs following a breast cancer diagnosis in a family member (Coyne et al., 2012; Northouse et al., 2012; Robbins et al., 2013) and this may affect the ways the family members engage with each other, communicate and interact, as well as their roles, family functioning and well-being (Coyne et al., 2012; Dieperink et al., 2017; Robbins et al., 2014). Despite the strain that breast cancer in a family member puts on the family as a unit, families often feel that their needs as a family are seldom seen or met by the health care (Coyne et al., 2017). However, research is starting to better comprehend the needs of families where a family member is diagnosed with breast cancer and to consider the family as a unit that includes both the patient and family members (Dieperink et al., 2017). Overall, women and their family members express a need for encouraging and open 
communication and collaborative support from health care professionals following a breast cancer diagnosis (Coyne et al., 2012; Robbins et al., 2014; Stinesen-Kollberg et al., 2013).

A systematic review of psychosocial interventions for families with parental cancer showed that those interventions were considered helpful (Inhestern et al., 2016). The interventions were mainly aiming at improving the communication between family members and at supporting children's adaptation to and understanding of cancer, and they consisted of counselling or conversations and were either family centred or person centred. Moreover, the review showed that the interventions have to be flexible, easy to access and offered as a routine care to reach a broader range of families in need of support. Although the findings also showed that the variability in study populations and intervention design makes generalising findings from studies difficult (ibid.), family interventions in oncological care addressing the whole family have shown improvements in quality of life, psychological health and depressive symptoms in parents as well as children (John et al., 2013; Thastum et al., 2006).

Family Health Conversations (FamHC) were developed in Sweden by Benzein and colleagues $(2008 ; 2017)$ by culturally adapting the practice models of Family Systems Nursing (Wright \& Bell, 2009; Wright \& Leahey, 1994, 2013). Family-focused care is grounded in the belief that health and illness in a family member affect the other family members both as individuals and as a family (Benzein et al., 2008; Wright \& Leahey, 2013), and it has a systemic approach that focuses on the interactions and relationships within the family with the aim of preserving health and facilitate healing. The systemic approach also means that family members' experiences and beliefs are seen as equally significant as those of the person with a diagnosis (Wright \& Leahey, 1994, 2013). Family-focused care consists of two approaches, namely, family-related care and family-centred care (Benzein et al., 2017). Family-related care places the emphasis on individual family members (persons with illness or other family members), while the rest of the family is seen as the context (Benzein et al., 2017; Wright \& Leahey, 2013). Family-centred care, on the other hand, focuses on the family as a unit from the perspectives of several family members concurrently (ibid.). Family Health conversations (FamHC) are offered to families with the purpose of creating a context for change in family health as well as supporting the creation of new beliefs, meanings and relationship opportunities specific to the story narrated by the family (Benzein et al., 2008; Wright \& Bell, 2009; Wright \& Leahey, 2013). 
Short Family Health Conversations (SFamHC) are a condensed form of FamHC and influenced by the '15-Minute Family Interview' developed by Wright and Leahey (1999). The reason for developing the 15-Minute Family Interview was the recurrent concerns raised by nurses about not having enough time to involve families in nursing care (Wright \& Leahey, 1999), an argument that is still valid (Dieperink, 2017; dos Santos Ribeiro Silva et al., 2013).

In the first SFamHC all family members are invited to narrate their experience of their present situation and listen to each other's stories. The SFamHC are held with one or two nurses as conversational leader/s, posing reflective and interventive questions, for example, 'In what way are you affected as a family by X's illness?', 'Who in the family is most affected?' and 'What is affecting how you handle the situation?' (Benzein et al., 2008; Wright \& Bell, 2009; Wright \& Leahey, 2013). The family prioritises, in collaboration with the conversational leader, the most relevant topics to focus on. The second SFamHC focuses on beliefs and problems brought up in the first conversation, while the third conversation revolves around the strengths and resources within the family as well as how these might help the family to reduce difficulties and increase well-being in the future. During the SFamHC, the conversational leader cooperates with each family in comprehending the family structure by making a genogram as well as visualising the family's contact with the larger system through the creation of an ecomap. The conversational leader also offers reflections and commendations to the family.

Previous research has shown that families experience a positive impact from participating in family health conversations and the 15-Minute Family Interviews in other contexts, for example, when a family member experiences chronic illness, cardiac and ischemic illness, depression or childhood cancer (Bell, 2015; Benzein et al., 2015; Östlund \& Persson, 2014). This suggests that more empirical studies are needed in the context of families where a family member is diagnosed with breast cancer.

\section{Rationale for this thesis}

Since breast cancer incidence is increasing and improved treatments lead to increased survivorship, women and their families are more likely to live with breast cancer and experience negative consequences of it. Consequently, a keen focus on the well-being of breast cancer survivors and their families is imperative. The Institute of Medicine and National Research Council high- 
lights the significance of specific points along the cancer continuum, with particular attention given to time for diagnosis and the end of treatment (Hewitt et al., 2006). The end of active treatment is often associated with a decline of support from health care professionals and for women with breast cancer the radiotherapy is often the end of active treatment.

Hence, needs that are unmet at this time might be neither assessed nor dealt with further on, which is why there is a need to know how the woman with breast cancer and her family experience their everyday life during radiation therapy. Knowledge is also needed concerning how women experience BART, since it requires an active participation and could be perceived as something that makes the radiation therapy even more stressful. In a multicultural society, like Sweden, the frequency of contact with immigrant women with breast cancer will increase, and so will, consequently, the need for extended knowledge of their experiences following a breast cancer diagnosis, in order to meet their needs. Despite increased globalisation, research elucidating the experience of breast cancer and radiation therapy among immigrant women from the Balkans and non-European countries is still lacking. By creating an understanding of how women and their families perceive their new life situation, and how they interact and function following a breast cancer diagnosis, we can develop caring strategies to identify the woman's and the family's needs as well as resources for those families that are in need of support. This might contribute to increased well-being for the individual as well as for the family as a unit in both the short- and the long-term perspective. In familyfocused care, it is crucial to understand both the parts (the individuals) and the whole (the family as a unit) in order to gain sufficient knowledge about the families' life circumstances. Therefore, both family-related and family-centred studies are needed to increase knowledge about the challenges faced by these women and their families and how they influence family members' health and well-being and their ability to understand and manage their situation in a meaningful way. 


\section{AIMS}

The overall aim of this thesis was to explore the experiences of everyday life during radiation therapy from the perspectives of the woman with breast cancer and her family, and to explore families' experiences of participating in short family health conversations (SFamHC). More specifically, the aims of the thesis were the following:

- To describe and analyse how women with breast cancer experience breathing adapted radiation therapy (BART) and to explore how women manage daily radiation therapy (Paper I)

- To explore how women from Iraq and the former Yugoslavia, diagnosed with breast cancer and living in Sweden, experience their everyday life during radiation therapy (Paper II)

- To elucidate family members' lived experience when a family member is diagnosed with breast cancer (Paper III)

- To explore families' experiences of participating in short family health conversations (SFamHC) following a breast cancer diagnosis (Paper IV) 


\section{METHODS}

This thesis used an exploratory approach in order to explore different aspects of living with a breast cancer diagnosis from the perspectives of the woman with breast cancer and her family members. A qualitative method was used for the data collection in order to gain a deeper insight into everyday life during radiation therapy from the perspectives of women with breast cancer and their family members, as well as for exploring how families experience their participation in short family health conversations (SFamHC) when a family member is diagnosed with breast cancer. An overview of the studies is presented in Table 1.

\section{Setting}

All of the studies were conducted in a region in the south of Sweden, comprising 1.3 million residents in a multicultural context where 23 per cent are foreign born (Statistics Sweden, 2018). All women and families were recruited at a radiation therapy department at a university hospital. Every year approximately 900 women with breast cancer undergo radiation therapy with a curative intention at the department. The author has been working as a specialist oncology nurse at this department since 2003 but was not involved in the care or treatment of any of the participating women. 
Table 1: Overview of the studies included in the thesis

\begin{tabular}{|c|c|c|c|c|}
\hline & Study I & Study II & Study III & Study IV \\
\hline Design & $\begin{array}{l}\text { Qualitative } \\
\text { design }\end{array}$ & $\begin{array}{l}\text { Qualitative } \\
\text { design }\end{array}$ & $\begin{array}{l}\text { Qualitative } \\
\text { design }\end{array}$ & $\begin{array}{l}\text { Qualitative } \\
\text { design }\end{array}$ \\
\hline Aim & $\begin{array}{l}\text { To describe and } \\
\text { analyse how } \\
\text { women with } \\
\text { breast cancer } \\
\text { experience } \\
\text { breathing } \\
\text { adapted } \\
\text { radiation ther- } \\
\text { apy (BART) } \\
\text { and to explore } \\
\text { how women } \\
\text { manage daily } \\
\text { radiation ther- } \\
\text { apy }\end{array}$ & $\begin{array}{l}\text { To explore how } \\
\text { women from } \\
\text { Iraq and the } \\
\text { former } \\
\text { Yugoslavia, di- } \\
\text { agnosed with } \\
\text { breast cancer } \\
\text { and living in } \\
\text { Sweden, } \\
\text { experience their } \\
\text { everyday life } \\
\text { during radiation } \\
\text { therapy }\end{array}$ & $\begin{array}{l}\text { To elucidate } \\
\text { family } \\
\text { members' lived } \\
\text { experience } \\
\text { when a family } \\
\text { member is } \\
\text { diagnosed with } \\
\text { breast cancer }\end{array}$ & $\begin{array}{l}\text { To explore } \\
\text { families' } \\
\text { experiences of } \\
\text { participating in } \\
\text { short family health } \\
\text { conversations } \\
\text { (SFamHC) when a } \\
\text { family member is } \\
\text { diagnosed with } \\
\text { breast cancer }\end{array}$ \\
\hline Participants & $\mathrm{n}=20$ women & $\mathrm{n}=10$ women & $\begin{array}{l}\mathrm{n}=19 \text { family } \\
\text { members } \\
\text { (6 families) }\end{array}$ & $\begin{array}{l}\mathrm{n}=9 \text { families } \\
(29 \text { family mem- } \\
\text { bers })\end{array}$ \\
\hline $\begin{array}{l}\text { Data collec- } \\
\text { tion period }\end{array}$ & Spring of 2010 & $\begin{array}{l}\text { March 2013- } \\
\text { March } 2014\end{array}$ & $\begin{array}{l}\text { January 2014- } \\
\text { July } 2014\end{array}$ & $\begin{array}{l}\text { December } 2016 \text { - } \\
\text { September } 2017\end{array}$ \\
\hline $\begin{array}{l}\text { Data collec- } \\
\text { tion }\end{array}$ & $\begin{array}{l}\text { Individual } \\
\text { interviews }\end{array}$ & $\begin{array}{l}\text { Individual } \\
\text { interviews }\end{array}$ & $\begin{array}{l}\text { Individual } \\
\text { interviews } \\
\text { conducted } \\
\text { on two occa- } \\
\text { sions }\end{array}$ & Family interviews \\
\hline $\begin{array}{l}\text { Data } \\
\text { analysis }\end{array}$ & $\begin{array}{l}\text { Qualitative } \\
\text { content } \\
\text { analysis }\end{array}$ & $\begin{array}{l}\text { Qualitative } \\
\text { content } \\
\text { analysis }\end{array}$ & $\begin{array}{l}\text { Hermeneutic } \\
\text { phenomenology }\end{array}$ & $\begin{array}{l}\text { Thematic content } \\
\text { analysis }\end{array}$ \\
\hline
\end{tabular}




\section{Participants}

The participants consisted of four unique samples and they were consecutively recruited according to the inclusion criteria of each study (Paper I, II, III \& IV). In order to describe and analyse how women with breast cancer experience breathing adapted radiation therapy (BART) and explore how they manage daily radiation therapy (Paper I), data was collected from 20 women of an age ranging from 32 to 69 years ( $\mathrm{md}=59.5)$. The inclusion criteria were: women aged 18 years or older, receiving curative BART for left-sided breast cancer and able to speak and write Swedish. The included women had all undergone breast cancer surgery; eight of them had received chemotherapy, and they received radiation therapy for 16 days $(n=6), 25$ days $(n=12)$ and 33 days $(n=2)$.

With the purpose of exploring how foreign-born women, diagnosed with breast cancer and living in Sweden, experience their everyday life during radiation therapy (Paper II), data was collected from 10 women, five originating from Iraq and five from the former Yugoslavia, aged 42-73 ( $\mathrm{md}=50$ ). The inclusion criteria were: women receiving curative radiation therapy for breast cancer, aged 18 years or older, and born in Iraq or the former Yugoslavia. The women had all undergone breast cancer surgery; three of them had received chemotherapy, and they received radiation therapy for 25 days $(n=7)$ and 16 days $(n=3)$.

With the aim of elucidating families' lived experience when a family member is diagnosed with breast cancer (Paper III), data was collected from six families. The inclusion criteria were: Swedish-speaking families where the woman was diagnosed with breast cancer and receiving curative radiation therapy, with children aged 12 and older living at home. Data was collected from 19 family members including the six women with breast cancer. The participants were six women (mothers) aged 41-55 ( $\mathrm{md}=48.5)$, three men (fathers) aged 39-58 (md=48) and 10 children, whereof three boys aged 12-14 $(\mathrm{md}=13)$ and seven girls aged 12-20 $(\mathrm{md}=16)$. The women had all undergone breast cancer surgery, had received chemotherapy and had received radiation therapy for 25 days.

In order to explore families' experience of participating in short family health conversations (SFamHC) in connection with breast cancer and radiation therapy (Paper IV), data was collected from nine families. The inclusion criteria were: Swedish-speaking families that had participated in a series of three SFamHC, with children aged 12 and older, where the woman was diagnosed with breast cancer and about to receive curative radiation therapy. The participating families consisted of 13 parents, that is, nine women (mothers) 
aged 43-56 ( $\mathrm{md}=48)$, four men (fathers) aged 44-57 ( $\mathrm{md}=48)$ and 16 children, whereof eleven boys aged 12-22 ( $\mathrm{md}=13)$ and five girls aged 15-25 ( $\mathrm{md}=19)$. The included families consisted of between two and four family members; five families were single-parent households and four married couples' households. The mothers in the participating families had all undergone breast cancer surgery; six of them had received chemotherapy, and they received radiation therapy for 25 days $(\mathrm{n}=6), 20$ days $(\mathrm{n}=2)$ and 15 days $(\mathrm{n}=1)$.

\section{Procedure}

The women and family members were given verbal and written information about the relevant studies (Paper I, II, III \& IV), although the procedure varied. Registered oncology nurses at the radiation therapy department served as gatekeepers and informed the women of the possibility to participate in the different studies (Paper I, II, III \& IV). Before the start of each study, the author of this thesis gathered the gatekeepers for information about the study regarding the aim, design, inclusion criteria and ethical principles according to the World Medical Association (WMA) (2013) as well as regarding the written information material. Further, the gatekeepers were asked to contact the author if questions should arise. The gatekeepers provided verbal and written information about the study (Paper I \& II) in the later part of the women's radiation therapy period. The women who chose to participate gave written, informed consent to the gatekeeper, and the consenting participants were contacted by the author and a time and place, chosen by the woman, was scheduled for the interview (Paper I \& II). The written information was translated into Arabic and Bosnian for the women who did not understand Swedish, and interpreters were used when needed (Paper II).

Potential participants were approached at their first visit at the RT department, in connection with the preparation for radiation therapy, and the gatekeepers asked permission for the author of this thesis to inform about the study (Paper III \& IV). Women interested in participation signed a consent form for the release of their contact information and received written information addressed to themselves and their adult family members, as well as age-specific written information for their children. A primary school teacher and three children, aged 12,14 and 16 years, tested the age-specific written material for its readability and comprehensibility before the initiation of the study. The definition of family used in these studies was 'the family is who they say they are' (Wright \& Leahey, 2013, p. 55). This definition was ex- 
plained to the women and they were asked to identify close family members who shared the illness experience and whom they specifically defined as belonging to their family.

The women were given two days to reflect and to discuss their participation with their family and were then contacted by the author by telephone. The author gave additional information about the study to the women who had agreed to participate, and a time and place, chosen by the families, was scheduled for the first interview (Paper III) and the first short family health conversation (SFamHC) (Paper IV).

The families in study IV were given the Swedish version of the General Functioning Scale (S-GFS) (Bylund et al., 2016), and also a demographic questionnaire, before the first SFamHC. The General Functioning Scale (GFS) is a part of the well-established McMaster Family Assessment Device (FAD) (Epstein et al., 1983), designed to measure self-perceived general family functioning and to distinguish between healthy and unhealthy family functioning. The GFS has a cut-off score at 2, indicating perceived unhealthy family function at scores from 2 and above (ibid.). The self-perceived general family functioning, assessed with the S-GFS, ranged from 1.15 to 2.06 (mean=1.64, md=1.59), indicating that most families experienced a healthy family functioning (Paper IV).

Written, informed consent was obtained from all participants, except children younger than 15 years, who gave their verbal assent and whose parents gave their written informed consent (Paper I, II, III \& IV).

\section{Data collection}

\section{Interviews}

Data was collected using individual interviews with women with breast cancer (Paper I \& II), and with women with breast cancer and their family members (Paper III), respectively. Family interviews were chosen as a method for data collection in paper IV since the purpose was to collect rich narratives from the whole family about their experiences of participating in the short family health conversations (SFamHC). Family interviews emphasise the shared family experience and family meanings, as well as bringing attention to the multiple voices within families, voices which are both autonomous and related (Donalek, 2009; Eggenberger \& Nelms, 2007; Hartrick \& Lindsey, 1995). 
The interviews with the women were conducted in connection with their last radiation therapy treatment (Paper I \& II). The individual interviews with the family members were held on two different occasions, the first in connection with the start of the woman's radiation therapy and the second interview two weeks after completion of the radiation therapy (Paper III). The reason why the interviews were conducted at two different points of time was that multiple interviews can, according to van Manen (2001), generate a deeper meaning and allow the participants to reflect on their lived experience (Paper III). The children were informed of the possibility to have one of their parents present during the interviews, although all of the children rejected this possibility (Paper III). The family interviews were conducted two weeks after the last short family health conversations (SFamHC) were held with the family (Paper IV).

The intention with all of the interviews was to enable the participants to narrate their experiences as freely as possible. In order to further the aim of exploring the experiences of women, family members and families, the interview technique used by the interviewer was influenced by Mischler (1996). Each interview began with the interviewer introducing herself, giving a clarification of the aim of the study and providing an opportunity for the participants to ask further questions about the study. This was done in a conversational form, in order for the participants to feel at ease but also in order to give the interviewer an opportunity to individualise each interview situation (Mischler, 1996). In study I, the women were asked to describe, in their own words, their experience of receiving breathing adapted radiation therapy (BART) and how they managed their daily radiation treatment, while in study II the women from Iraq and the former Yugoslavia were asked to describe their experience of radiation therapy. The first individual interview with the woman and her family members started with the open question: 'Can you tell me about when you found out that you/your mother/your wife had breast cancer?', while the second interview began with a summary of the participants' own narrative from the previous interview, and then the participants were asked to freely narrate and reflect on their lived experience when a family member is diagnosed with breast cancer (Paper III). As for the family interviews, they started with an open question about the families' experiences of their participation in the short family health conversations (SFamHC) (Paper IV). Thematic interview guides were used to enable adjustment of both the form and the sequence of follow-up questions depending on the answers given and the stories told by the participants (Paper II, III \& IV). 
The use of thematic interview guides was chosen because, according to Patton (2002), it enables the interviewer to reach greater depth in the interview, to cover a sequence of themes and to open up for a freer conversation. Each interview guide was developed after reviewing the literature in the field specific for each study. The interview guides focused on everyday life, and physical and emotional aspects of everyday life (Paper II), on family life, everyday life, and physical and emotional aspects of family life and everyday life (Paper III), and on positive and negative experiences of participating in SFamHC, and the possible contribution of the SFamHC to any changes for the family, as well as the family's possibility to influence the format and the content of the SFamHC (Paper IV). Additional open follow-up questions, such as 'How did it feel?', 'Could you describe...?' and 'What was it like?', were frequently posed during the interviews, to give the participants a possibility to expand the description of their personal experiences, to clarify or further elaborate their answers and to confirm their understanding of the questions (Paper I, II, III \& IV).

Pilot interviews were made with three women (Paper I) and two families (Paper III), respectively, before initiating the studies, and those interviews were all included since they were considered relevant and produced enough relevant data to answer the aim of the study. Before the start of study II, one woman from Iraq and one woman from the former Yugoslavia, who were not included in the study, were interviewed and the interview guide was tested for its suitability, whereafter adjustments were made. Three female, authorised interpreters were used, two of them Bosnian and one Iraqi, commissioned through a national interpretation agency (Paper II). Prior to the interview, the interpreters were thoroughly informed about the aim of their assignment, as interpreters should be considered a research tool, according to Temple (2002), and must be well informed about the aim of the interview (Kapborg \& Berterö, 2002). The interpretation was consecutive and the interviewer directly faced the participants during the interviews. The interviewer also tried to be attentive to how the questions seemed to affect the women, since there might be cultural differences regarding what subjects to discuss with strangers, and since using an interpreter might exclude the interviewer from certain parts of the dialogue. Furthermore, triangular seating was used, since it might help the interviewer remain in control of the interview and make sure that the interview is between the interviewer and interviewee as well as making the interpreter less intrusive, according to Wallin and Ahlström (2006) (Paper II). 
Throughout all interviews the interviewer tried to balance the interview by sharing the silences that arose and waiting for the participant to proceed ( $\mathrm{Pa}-$ per I, II, III \& IV). Moreover, the interviewer was especially attentive and responsive to how the children perceived the situation, endeavouring to use a language that was easy to understand, as well as explaining, without being directive, if the child did not seem to understand (Paper III). All interviews lasted as long as needed for each participant or family to narrate their story and until no follow-up questions triggered a continuation but a calm silence occurred. All interviews were electronically recorded for later transcription.

The participants in all studies chose the place and time for the interviews. All the interviews with the women $(n=30)$ took place in a secluded room at the radiation therapy department (Paper I \& II). The families, however, chose their home as the location for the interviews ( $\mathrm{n}=14$ families) (Paper III $\&$ IV), except one family who chose a secluded room at the radiation therapy department (Paper III).

The electronic files with the interpreted interviews were sent to another national interpretation agency in Sweden for an extra, independent translation (Paper II). This was done in order to minimise the risk of unspoken metacommunication that might occur in a transcultural interview where the participant and interpreter share the same coherence system (Wallin \& Ahlström, 2006). Meta-communication is often hidden from the interviewer, and may cause misunderstanding, misinterpretation and an unreliable result (Ingvarsdotter et al., 2010). No discrepancies were found between the translated interviews and the actual interviews (Paper II).

\section{Data analysis}

In this thesis, three different qualitative methods have been used for the analysis. An inductive approach (Polit \& Beck, 2017) was taken for all studies (Paper I, II, III \& IV), letting the collected data speak for itself, without letting the analysis be driven by a predetermined framework, theory or structure. All data in the included papers was managed 'by hand', and the analysis started with the author listening to and subsequently transcribing the interviews (Paper I, II, III \& IV).

Qualitative content analysis influenced by the work of Burnard (1991, 1996) and Burnard et al. (2008) was used to analyse the interviews (Paper I \& II) in order to develop a thorough and systematic overview of the women's 
experiences. Qualitative content analysis was, furthermore, used to comprehend the manifest data and to interpret the underlying meaning. Qualitative content analysis is a systematic analysis of narratives aiming at condensing and making sense of a voluminous number of words, and serving to identify prominent patterns and themes (Patton, 2002; Polit \& Beck, 2017). The author of this thesis listened to the interviews and read all transcribed interviews simultaneously in order to check the correctness of the transcripts, become familiar with the text and get a sense of the whole. Sentences and phrases that described the experiences of the women were first compiled and then condensed and coded in an open coding. The coded units were sorted and grouped into categories that provided an initial coding framework for exploring the women's experience of breathing adapted radiation therapy and how they managed their daily radiation therapy (Paper I) and the women's experience of everyday life during radiation therapy (Paper II), respectively. The experiences of the women from Iraq and the former Yugoslavia were analysed separately in the first stage (Paper II). Throughout the analysis process, continual back-and-forth referencing was carried out between the entire text and parts of the text. During analysis the underlying meaning, that is, the deeper meaning behind the women's experiences, was interpreted. The categories derived from the Iraqi women and those from the women from the former $\mathrm{Yu}$ goslavia were compared and contrasted in the final stage of the analysis (Paper II). The author first performed the analyses independently and then together with the other authors in a discussion aiming to reach a consensus among the authors (Paper I \& II).

A hermeneutical phenomenological method influenced by van Manen (2001) was used for the analysis of the individual family members' interviews, as it enables a deeper understanding of the nature of the families' lived experiences when a family member is diagnosed with breast cancer (Paper III). Hermeneutical phenomenology is an approach that is rooted in philosophy, aiming to describe lived experiences in as detailed, concrete and multifaceted a way as possible (van Manen, 2001). According to van Manen (2001), a hermeneutic phenomenology approach should make a phenomenon explicit through writing, and assist the reader in 'seeing' the phenomenon in a different way that enriches their understanding of it. This also means that hermeneutic phenomenology is at bottom a writing process, with the researcher as an active co-creator in the analysis and writing process (ibid.) The analysis began during the interviews, where the author listened and paid attention to the meaning of the participants' narratives. The author then read and reread all 
family members' transcripts to obtain an understanding of the overall text. An analysis of the transcripts using a line-by-line approach influenced by van Manen (2001) was made. Each sentence or cluster was explored in order to find out what it revealed about the meaning of living as a family when a member of the family is diagnosed with breast cancer. These sentences were then highlighted and tentative theme designations written down, in order to understand the families' experience, both as individuals and as a unit. The essence of the themes, as well as their variations, were discussed among the authors, in order to generate a deeper insight into, and an understanding of, how the family's experience as a unit is formed by each family member's experience. Thereafter followed a comprehensive procedure of writing and rewriting, where the author was fully focused on the phenomenon of interest in order to elucidate family members' lived experience when a family member is diagnosed with breast cancer.

Thematic content analysis influenced by Braun and Clarke (2006) was used to analyse the interviews with the aim of exploring families' experience of participating in short family health conversations (SFamHC) following a breast cancer diagnosis in the family (Paper IV). The reason thematic content analysis was used is that it is suitable for exploratory studies aiming at identifying, analysing and reporting patterns (Braun \& Clarke, 2006), as well as making interpretations of different aspects of the area of interest (Boyatzis, 1998). The analysis was made in six stages, in accordance with Braun and Clarke (2006). The thematic content analysis is a progressive and iterative process rather than a linear one (Braun \& Clarke, 2006). The first step was to familiarise with the data and it started with the author transcribing the interviews and making notations about additional interview features, such as voice inflection, silence, laughter, etc. The authors read and reread all transcripts to obtain an understanding of the overall text and then began to identify data relevant to the research question. The second stage in the analytic process was the coding, which was done so that the codes captured both the semantic and the conceptual reading of the data. The author and one of the co-authors of the paper independently coded every data item and ended this stage by collecting all codes in order to organise the qualitative data. In the next stage, potential themes were identified from the codes, based on patterns and clusters of meaning within the data set, keeping the aim of the research in mind. In the fourth stage, themes were reviewed and inspected in order to ascertain that the themes were accurate in relation to both the coded data and the transcripts. This stage also involved reflections on whether the themes were convincing 
and on the relationships between the themes. In the fifth stage, the essence of the themes was pinned down by defining and naming them. The last stage meant writing, and, in doing so, intertwining the analytic story with significant and representative quotes to present a comprehensible and credible story about the families' experiences of participating in SFamHC.

\section{Pre-understanding}

Pre-understanding can be described as what the researcher brings to a study; it shapes the ways in which the researcher understands a topic and it is important to 'put into play' as a way of extending that understanding (Gadamer, 2004). The pre-understanding might influence both the creation and the interpretation of the research and its results (Nyström \& Dahlberg, 2001). Further, the researcher's perspective is affected by factors like origin, culture, personal beliefs, educational level and professional experiences as well as lived experience. Pre-understanding originates from something that the researcher is familiar with, either context or tradition, and it might facilitate but also constrain understanding (ibid.). The researchers do not need to 'bracket' their preunderstanding, attempting to hold it in abeyance, but rather to situate it in relation to their understanding and make it explicit (Gadamer, 2004). It is essential to have an open attitude so as to see what really is discovered and be able to comprehend something new, in order to reduce the risk of solely confirming what is already known (Lincoln \& Guba, 1985; Nyström \& Dahlberg, 2001). As van Manen (2001) states, it is better to be deliberately aware of one's assumptions, beliefs and theories, throughout the research process, than to forget them. Thus, making their pre-understanding explicit may prevent the researchers' knowledge from influencing the analysis process in a subjective manner.

The author is an oncology nurse and has been working in a radiation therapy department, meeting, treating and caring for women with breast cancer and their family members for several years, and she has met many individuals from different backgrounds and different kinds of relationships and with multiple and various needs and thoughts. However, she has not been involved in the care or treatment of the women in the studies included in this thesis.

Before initiating the research process, the author tried to make her preunderstanding in oncology nursing explicit in order to avoid predisposed interpretations of the phenomenon under study. This endeavour was ongoing throughout the research process and especially before initiating the analysis of 
each study. Being aware that the pre-understanding might influence the quality of the data collection and analysis, the author tried to meet all participants with an open mind, focusing on the individual and their narrative and emotions. The author's experience and pre-understanding have also facilitated the contact and the encounters with the women and their families. Many participants verbally expressed that their participation became valuable to them through meeting a nurse with specific experience of this context and being interviewed by her. A regular and open dialogue with the supervisors and coauthors was held throughout the entire research process, which has helped to identify pre-understanding, reduce the risk of misinterpretations and increase confirmability (Lincoln \& Guba, 1985). 


\section{ETHICAL CONSIDERATIONS}

The four studies that comprise this thesis were conducted in accordance with the established ethical guidelines developed by the World Medical Association (WMA, 2013). Further, the ethical principles of autonomy, non-maleficence, beneficence and justice (Beauchamp \& Childress, 2013) were taken into account throughout the entire research process. However, those ethical principles are usually not sufficient when reflecting on a research situation, since that situation contains an interaction between the researcher and the participants. The concept of relational ethics, which focuses on the meetings and the relations between people, is needed as a complement and may serve as a bridge between ethical theories and the research situation (Bergum \& Dossetor, 2005; Øye et al., 2016). The studies included in this thesis were approved by the Regional Ethical Review Board in Lund (2012/712; 2013/589; 2016/649) and by the Health Sciences Ethics Committee at Lund University (VEN 98-09).

The principle of autonomy means that a person considered for participation in research has the right to gain knowledge and understanding of the research and its potential risks and benefits in order to make a decision (Beauchamp \& Childress, 2013). Thus, in order to facilitate for all participants to be able to give informed consent, different measures were taken. All potential study participants received information both orally and in writing regarding the purpose of each study and the data collection procedure, as well as about the fact that participation was voluntary and could be terminated at any time without a specific reason or any negative consequences. In study II, where immigrant women from Iraq and the former Yugoslavia were interviewed, the written information was translated and in some cases the women received the information in both Swedish and their own language to meet the information and consent requirement. In order to strengthen understanding, some of the wom- 
en were asked for participation with the help of an interpreter, and the written material could then be read together with the interpreter. Families, including children 12 years of age and older, participated in study III and IV. Since children begin to develop their abstract thinking by the age of 12, which means that they can have their own complex opinions and perceive multidimensional situations and thereby also weigh the pros and cons of participating in research (Belmont, 1989; Piaget, 1972), the lower age limit was set at 12 years. The children received age-specific information, written in an easy-tounderstand language and the first author tried to ensure that the information was perceived correctly before the data collection began. All participants were informed that the author of this thesis would conduct the interviews (Paper I, II \& III) and the Short Family Health Conversations (Paper IV) and that none of the researchers were involved in the women's treatment and care. The women and the family members were given time to consider their potential participation, before giving their informed consent.

The principle of non-maleficence means not to harm the research subjects, and medical research involving human subjects should only be conducted if the research question is relevant and useful to science or society and if the importance of the objective outweighs the risks and burdens of those participating (World Medical Association, 2013). In order to protect integrity and confidentiality all data was treated so that no individuals could be identified. All original data was kept safe and only accessible for the authors. Transcribed interviews, demographic questionnaires and S-GFS were marked with a letter and a number and did not contain any personal information. Data was computerised, analysed and presented on a group level. Published quotes were presented anonymously with the intention to avoid the probability for others than the participants themselves to distinguish and identify the person behind the quote. Participants were allowed to determine the place and time of the interviews so as to create favourable conditions and cause as few disturbances as possible in their privacy. All families except one wanted the interviews to take place in their home, and interviewing children in their home environment might decrease the asymmetrical relationship between the adult interviewer and the child (EVA, 2009). During interviews with the family members, they got to choose the order in which the interview should be conducted (Paper III). Participating in interviews can provoke feelings and thoughts within the participants that otherwise would not have been conveyed. Thus, the management of such situations was reflected on before the interviews, and during the 
interviews much attention was given to both the verbal and non-verbal signs of the participants.

The principle of beneficence means that participants will or may benefit from participating in the research and this requires striving for a balance between the pros and the cons of the participation. Many participants, both the women with breast cancer and the family members, expressed their appreciation of the possibility to talk about their experiences and feelings regarding the illness, the treatment and the impact on their everyday life. With regard to the children's participation in the studies, the interviews and short family health conversations were for some children the only occasion when they had spoken to an adult outside the family about their experiences of their mother's illness and treatment (Paper III \& IV). A good amount of time was set aside for the interviews in order for the interviewer to be able to stay and talk with the participants after the interviews. Furthermore, all participants were informed that a counsellor was available at the oncology clinic if the need should occur and contact details were distributed after the interviews (Paper I, II, III \& IV). However, none of the participants chose to utilise this opportunity.

The principle of justice means that all persons should be treated equally, and receive medical treatment according to need and regardless of sex, race, abilities and function (Beauchamp \& Childress, 2013). The women were consecutively invited to participate, which gave all patients who met the inclusion criteria equal possibilities to accept or decline participation. Participation in research should, among other things, include fair access to the benefits of research, for both patients (Paper I, II, III \& IV) and relatives (Paper III \& IV). In study II, immigrant women were interviewed about their experiences and it is well known that immigrants are to a lesser degree included in research, which is sometimes related to language barriers. The women were offered interpreters as well as translated written material to give them a fair chance of taking a stand for participation, to avoid any misunderstanding of the questions in the interview, and to give them the possibility to express their experiences. Previously, research has attempted to avoid including children, but children have a great ability to contribute their experiences of a situation. It is a matter of justice that those who are willing and able to participate in research and express their thoughts are allowed to do so.

With regard to relational ethics, 'no man is an island, entire of itself' (Donne, 1623/1988), but every human is always in a relational context, such as the family (Wright \& Leahey, 2013), something which must be noted in the case of illness and treatment, but also in research. A pertinent question in this 
context is what the researcher brings to the interview situation regarding values and personality. Relational ethics have been described by Bergum and Dossetor (2005) in four components: mutual respect, commitment, embodiment and environment. The researcher must respect the informant, but the informant must also respect the researcher in the interview situation. Mutual respect in an interview situation requires that the informant and the interviewer see each other as equals with differences, knowing that they affect each other with their actions and that there is a mutual dependency. According to Martin Buber (1994), 'there is nothing isolated, I am always in relation to I-Thou and I-It', that is, a person is always in relation to the outside world. The interviewer must perceive, see and acknowledge the informants, in this case women with breast cancer and their family members, as individuals already in a weave of relationships. By seeing the informants as individuals, listening to their story and being present at the meeting, the interviewer is also involved, which could be interpreted as 'commitment' (Bergum \& Dossetor, 2005). 'Embodiment' represents the whole of a person, that is, a thinking mind and a sensing, experiencing body, both of which should be taken into account by the interviewer. 'Environment' extends the concept of relational space beyond the individual level and explores the network of relationships that link the individual to the family, the society, the state or the health care industry (ibid.). This environment is changing all the time and humans change with it. For the women, their relationship with their environment has changed due to their cancer diagnosis (Paper I, II, III \& IV), for the foreign-born women also due to their migration (Paper II), and for the children and husbands, their relationship with their mother and wife, as well as with their environment, has changed because of the illness of their loved one (Paper III \& IV).

When conducting family research containing family interviews (Paper IV) there are special ethical challenges that must be considered. There is a potential threat that the research situation may create conflicts between the participants when they are closely related (Voltelen, 2017). Issues and statements may arise during the research situation that are discussed for the first time; this can bring awareness of the multiple voices within the family but it can also lead to family members regretting things they said. The interviewer tried to be attentive to the family members' reactions, allowing everyone to express their opinions, not letting one participant dominate and not taking sides between participants. Listening to each other might have a positive impact on the family members, giving them a possibility to discuss issues brought forth. 
At the same time, it should be noted that the researchers have no or limited knowledge about how the families' participation affected them afterwards. 


\section{FINDINGS}

The overall aim of this thesis was to explore the experiences of everyday life during radiation therapy from the perspectives of the woman with breast cancer and her family, and to explore families' experience of participating in short family health conversations. The detailed findings of the included studies are reported in the respective papers (Paper I, II, III \& IV). When summarising the results from each paper some prominent and overarching findings emerged. The most prominent findings showed that the experiences of the women and their families could be described as a journey for survival, a journey that started at the time of diagnosis and that they were still partaking in. The journey for survival sent them off into the unknown, where they strove to regain control, balancing between hope and despair, experiencing their life as divided into an outer and inner world and needing support from each other as well as from health care professionals (Paper I, II, III \& IV).

\section{Entering the unknown}

The women felt that life had been completely overturned for themselves and their families as they were diagnosed with breast cancer. Although the women experienced uncertainty already when they detected a lump or were recalled for further diagnostics after their mammography screening, they all saw the revealing of the diagnosis as the starting point for their journey for survival (Paper I, II, III \& IV). For the family members, the diagnosis also became a life-changing event that set them off on an unknown journey trying to find their way back to their former well-known territory (Paper III \& IV). During radiation therapy the everyday life of the women and their families was still impacted by the moment the diagnosis was revealed (Paper I, II, III \& IV). 
They were also searching for strategies for navigating through the new, unknown and frightening life situation (Paper I, II, III \& IV).

Furthermore, the women felt that they lived in a process and a cancer continuum where the diagnosis was seen as a potential death sentence (Paper I, II $\&$ III). The treatment trajectory was an unknown territory with side effects they were unable to predict (Paper I, II \& III) and the women experienced the high-technology radiotherapy department as hopeful and a source of security, as well as frightening because it was an unknown environment (Paper I).

The families felt as if they were drifting out into the unknown, not knowing how to regain the ordinary, safe life that they had lost (Paper III). They found themselves fumbling in the dark, as they did not know where they were or in what direction they were going. Life as they knew it had disappeared together with their usual, familiar roles and functions. The husbands felt a need to stay in control and bring their family to safety, but had to accept facing the unknown and continue to fumble in the dark (Paper III). The families did not know how or where to seek help and support, or if there even was anyone who could guide them (Paper III \& IV). They were concerned about the present as well as about what the future would bring them, which made them both long for and dread the future. Everyday life became a long wait branded by insecurity and ignorance, and they were in need of information regarding the illness, the treatment and the side effects and outcomes of the treatments (Paper III). Although the families wanted guidance in how to proceed and regain their ordinary life, they experienced both reluctance and distress before the first SFamHC as this was also an unknown territory (Paper IV). However, their initial unease was transformed into a more comfortable and relaxed state during the conversations (Paper IV).

\section{Regaining control}

Everyday life was experienced as a balancing act, trying to regain control after the received diagnosis, from the perspectives of both the woman and the family members (Paper I, II, III \& IV). The women experienced the diagnosis as an ever-present and potential hazard to their survival, no matter what (Paper I, II \& III). However, by focusing on breathing, the women perceived the treatment as less stressful, and the feeling of being in a meditative state during the breathing was helpful and soothing, and pushed other stressful thoughts aside (Paper I). The women also felt that participating in BART and breathing well 
made them feel stronger and increased their self-esteem, as well as helping them regain a sense of normality in their life situation (Paper I).

Both the Yugoslavian and the Iraqi women experienced their everyday life as a struggle not to let their façade of normality and health crack, as they thought it would harm their journey towards survival (Paper II). For the Yugoslavian women, the unexpected diagnosis led to an everyday struggle to try to understand what had caused their illness, and they expressed feelings of fatalism. Although expressing that the illness was determined by fate, they were intent on not giving up without a fight (Paper II). One strategy to maintain control was to turn to God, and the Iraqi women also expressed that their faith in God was a way to stay on top of their situation and that it helped them manage their everyday life (Paper II). The women's attempt to regain control also included a close cooperation with health care professionals (Paper I, II, III \& IV), minimised physical activity (Paper II) and a forced attempt to adopt a positive attitude (Paper I, II, III \& IV).

When pursuing balance, the families tried to manage treatment-related side effects, as well as trying to avoid the surge of emotions that threatened to overwhelm them (Paper III). They struggled to manage their unsteady journey by trying to keep each other safe and put the other family members' well-being before their own (Paper III \& IV).

The husbands felt as if their life fell apart and they experienced life as a balancing act, characterised by an increased insecurity as well as a fear of not being able to support their family emotionally (Paper III \& IV). Further, they tried to focus on the possibilities and on the thought that somehow they were going to make their way out of the darkness (Paper III). The children also expressed that they needed school and the space outside their home to be sanctuaries free from the intrusion of illness in order to manage, although the parents would have appreciated more support from school (Paper III \& IV).

\section{Balancing between hope and despair}

The women's everyday life was invaded by thoughts regarding the breast cancer diagnosis as potentially life threatening. They thought of their survival as something they must pursue not only for themselves but also for the sake of their family (Paper I, II \& III). The women and their families felt that they were caught in an emotional turmoil (Paper I, II, III \& IV), and the women expressed that the uncertainty left them with feelings of horror, despair and lost safety, which forced them to confront their own mortality (Paper I, II \& 
III). Those women who received breathing adapted radiation therapy (BART) experienced the breathing in multiple ways, but mostly in the positive sense that their breathing might increase their chances of survival (Paper I).

Their feelings oscillated between, on the one hand, sadness, worry and fear of recurrence and, on the other hand, hope, joy and gratitude for being alive (Paper II \& III). The women expressed overwhelming thoughts of death and the fear of not being able to continue to care for their children (Paper II \& III). After struggling to accept their diagnosis, they were walking a narrow treatment road towards survival, with side effects and death lurking on each side of the road, yet trying to stay positive (Paper II).

The children also became preoccupied with the outcomes of their mother's treatment, dreading that she would not survive (Paper III \& IV). They lived in ever-present fear of their mother being struck by illness, complications and treatment-related side effects, which made them constantly check her whereabouts (Paper III).

The families tried to stay positive about the future, but treatment-related side effects and fear of the progress of the illness forced them to take one day at a time (Paper III \& IV). Keeping the family together despite the intrusion of the illness, was a united but strenuous effort (Paper III \& IV).

The family members felt that the SFamHC had helped them to verbalise their feelings and thoughts, and also brought them an insight into each other's emotions, fears and questions (Paper IV). They expressed that earlier suppressed feelings and thoughts, such as fear of death and of the treatments and their side effects, and thoughts about how to communicate these, were important issues that were brought forth in the SFamHC. When these feelings and thoughts now could be shared it gave the family members a sense of relief. The families also expressed that the SFamHC gave them tools for communicating emotions and difficult issues as a family (Paper IV).

\section{Living in a divided world}

The women with breast cancer expressed a need to spare their family from the time of diagnosis and throughout the treatment trajectory (Paper I, II, III \& IV). They struggled to maintain a façade in front of the family, wanting to protect the children and manage their fragile life situation without involving them too much (Paper I, II, III \& IV). However, the changed roles and responsibilities made the women with breast cancer feel unable to protect their family and responsible for bringing illness and sadness to them (Paper II \& III). 
The support from family and friends was appreciated but also ambiguous since the assistance was sometimes associated with a fear of losing control (Paper II \& III).

Although experiencing a need for support from family and close relatives, the women tried hard to keep up appearances (Paper II \& Paper III). The Iraqi women even tried to avoid informing their families about their illness and treatment (Paper II). They also concealed their illness when talking on the phone to relatives living in their home country, which led to feelings of distress that increased a sense of being alone. This also emerged as a feeling of living in a divided world; one part was the women's authentic, but troubled inner world, and the other was the false, but seemingly happy and healthy outer world. For the Yugoslavian women it was their family, relatives and friends who were the source of support, and their support circle wanted to help them with everything (Paper II). Although the support was highly appreciated, the women expressed a need to stay on top of their situation and maintain control of their everyday lives during their journey towards survival (Paper II \& III).

The family members tried to cling to each other in order to support each other throughout the treatment trajectory (Paper III \& IV). Although working together to overcome the strenuous experience, they sometimes strove in opposite directions, due to the unknown situation in conjunction with their inability to communicate their emotions. The families were often disappointed with themselves as well as feeling let down by other persons in their vicinity (Paper III). Although the family members wanted their family to be seen as a unit, they also longed for their ordinary life where they enjoyed more space as individuals. Their difficulties in sharing and communicating the family burden that the illness brought upon them led to self-reproach and feelings of guilt (Paper III \& IV). The husbands wanted to carry the burden of illness and treatment for their wife but were struck by feelings of inadequacy (Paper III).

The children felt and appreciated that they got to spend more time at home with their mother, and they experienced an increased closeness between the siblings, and in the family overall, which helped them to provide leverage against their insecure life situation (Paper III \& IV). The children also felt guilty and inadequate, as they wanted to live their ordinary life with friends, on the one hand, and be at home with their mother and family, on the other hand (Paper III). They struggled with not knowing how to help and support their mothers and sometimes they just did not have the strength to acknowledge their mother's illness (Paper III \& IV). 
Thus, all family members tried to make sure, and reassure each other, that the family would reach a safe haven (Paper III).

\section{Needing support from the health care professionals}

The close contact with the nurses in the treatment team was seen by the women as a way to better manage their situation, since they experienced the nurses as empathic, attentive and giving clear and honest information (Paper I, II, III \& IV). Moreover, the women felt that continuity among the nurses in the treatment team facilitated a relationship that was an important factor for having a sense of better control and a calmer state. When feeling connected to and secure with the nurses, the women dared to ask questions which deepened their knowledge and made them more confident and secure (Paper I, II, III \& IV). They also felt that they could let their guard down in front of the nurses (Paper II). The availability and continuity among health care professionals helped them to stay on top of their situation, although unmet support needs concerning the well-being of their family made the women feel abandoned (Paper III \& IV). However, the younger women expressed a wish that the nurses had offered a 'half-time' conversation during the radiation period, since they felt that they did not always have the strength themselves to ask for further support or information (Paper I). The families were also concerned about the lack of understanding and support from health care professionals and school (Paper III), and the husbands experienced an unmet need of being seen and supported by the health care professionals (Paper III \& IV).

The families expressed that the participation in the SFamHC was a positive experience, albeit occurring too late in the treatment trajectory (Paper IV). The participation in the SFamHC made the families feel seen by the health care professionals and thereby also important. They felt that something had happened to them during the SFamHC, although they expressed that the effect or impression was hard to define. They families felt stronger and more capable as a family since they felt that their strengths and resources were confirmed in the SFamHC. Some family members also expressed a need for both individual and family conversations, since they felt that there were some issues that they did not want to reveal in front of each other. The participation in SFamHC made the families aware of their capability of going through a difficult situation together, and they felt supported as a family and as a unit. The families also felt that the extended knowledge gained during the SFamHC helped them to manage as well as being a confirmation that the family had coped with the strains 
from the breast cancer diagnosis. It was also seen as a way for them to get closure and move on to survival (Paper IV). 


\section{METHODOLOGICAL CONSIDERATIONS}

The qualitative and explorative design of this thesis contributes to a broader insight into the experiences and needs of the woman with breast cancer and her family from their own perspectives. This can be seen in how everyday life can both be considered from an individual perspective (Paper I, II \& III) and be viewed as an experience shared by a family (Paper III \& IV). Qualitative methods, with individual interviews (Paper I, II \& III) and family interviews (Paper IV), were chosen since qualitative research can provide rich narratives and insights into the experiences and perspectives of human beings (Patton, 2002). Qualitative studies can be assessed by means of the quality-affirming concept of trustworthiness with its four criteria: credibility, dependability, confirmability and transferability (Lincoln \& Guba, 1985). Efforts were made, throughout the whole research process, to enhance the trustworthiness of this thesis.

According to van Manen (2001), there are four existential dimensions connected to the fundamentals of the life world that have to be taken into account to ensure quality in qualitative research. The first dimension is the lived body and relates to how a person is always corporeally in the world and to the fact that it is through her bodily appearance that she first meets other persons (van Manen, 2001). Lived space refers to felt space, that is, the manner in which one's body inhabits a space and how it affects the way a person feels about herself, while lived time (temporality) is referred to as subjective time, as opposed to clock or objective time (ibid.). Lived other is defined by van Manen as 'the lived relation we maintain with others in the interpersonal space that we share with them' (van Manen, 2001, p. 104). The four 'existentials' were reflected upon during the analysis and discussion in study III, with the aim of reaching a deeper understanding of the lived experience of the families. 


\section{Credibility}

Credibility can be viewed in the light of whether the results present a truthful description of the participants' experiences (Lincoln \& Guba, 1985). The inclusion criteria were set with the intention of exploring the experiences from the perspective of the woman with breast cancer and her family members, as a phenomenon can only be understood by how it presents itself to the person who has experienced it (van Manen, 2001). The family members included in this thesis also comprised children, since it is only the children themselves who really can describe their experiences (Clarke, 2015). The interviews were conducted with women and families who had experience of everyday life during radiation therapy and of living with breast cancer (Paper I, II, III \& IV) as well as of participating in short family health conversations (SFamHC) (Paper IV).

The inclusion of participants and families in all studies was conducted by gatekeepers, i.e. oncology nurses, at the RT clinic, in the later part of the radiation therapy period (Paper I \& II) and at the first pre-treatment visit (Paper III \& IV). Consecutive sampling from one RT department was used in the studies (Paper I, II, III \& IV) to ensure a variety in the demographics of the participants. Since the radiation therapy clinic is a high-volume centre of RT, various demographic characteristics are represented, including women and families from rural areas. The credibility was also strengthened by the variations in age (Paper I, II, II \& IV), gender and family structure (Paper III \& IV).

Qualitative research does not attempt to generalise information (Lincoln \& Guba, 1985) but rather to elucidate the detailed and specific aspects of information. Patton (2002) states that there are no specific rules regarding sample size in qualitative research, but that it should be large enough to obtain feedback for most or all perceptions of the phenomenon. There are few guidelines for estimating suitable sample sizes (Marshall et al., 2013), but one approach is to apply recommendations by qualitative methodologists (ibid.). For phenomenological studies, sample sizes ranging from 3 to 10 (Dukes, 1984) and from 6 to 10 (Morse, 2000) are recommended and the sample size in study III, performed with a hermeneutical phenomenological approach influenced by van Manen (2001), consists of six families ( $\mathrm{n}=19$ participants).

Equivalent recommendations for content analysis and thematic analysis are lacking; however, another possibility is to follow sample sizes used in studies exploring similar research problems and using the same designs (Mason, 2010). Previous qualitative studies exploring the experiences of women with breast cancer from their own perspectives have included 16 and 21 participants (Engqvist Boman et al., 2017; van Ee et al., 2017), and the sample size 
with 20 participants (Paper I) can thus be said to correspond well with those sample sizes. Qualitative studies from the perspective of women with breast cancer who belong to an ethnic minority have included 19 (Lopez-Class et al., 2011) and 23 (Kwok \& White, 2014) participants, which suggests that the sample size with 10 participants (Paper II) could be considered small. Research using thematic analysis has included a wide range of participants, from 12-20 (Douglas et al., 2009; Schnur et al., 2009; Schnur et al., 2011a) to 67 (Braun et al., 2013), which might indicate that nine families are a small number although the families consisted of 29 family members (Paper IV). Further, no new data emerged in the later part of the data collection period; rather it seemed as if the issue of interest was thoroughly researched with no reason for further participants to be included (Paper I, II, III \& IV). Study III comprised interviews on two occasions with every participant, since van Manen (2001) states that taking part in more than one interview will allow the participants to reflect on their narratives. In order to make the participants feel comfortable and share their experience, the place for the interviews was chosen by the participants (Paper I, II, III \& IV).

\section{Dependability}

Dependability refers to the stability of data over time, and concerns whether or not the interpretations of the data are representative of the context and group of participants (Lincoln \& Guba, 1985; Polit \& Beck, 2017). To increase the credibility, all interviews with the women, family members and families were conducted by the same interviewer (the author) in study I, II and III. The author is an oncology nurse with extensive experience of conversing with women and family members in an oncological setting. In study IV, all interviews were conducted by VV, who is a paediatric nurse and researcher, with extensive knowledge of conversing with, as well as interviewing, children and parents. Both authors conducted all the interviews in the same manner and posed similar follow-up questions to all the participants, which might strengthen dependability. Efforts were also made during the interviews to achieve a mutual understanding of the meaning of the questions and responses, as well as inviting the respondents to develop their narratives; this approach was even more emphasised when an interpreter (Paper II) or children (Paper III \& IV) were present. 


\section{Confirmability}

Confirmability refers to the objectivity of the data, that is, the findings should represent the participants' information and narratives and not be biased by the researcher's perspective or subjectivity (Lincoln \& Guba, 1985; Polit \& Beck, 2017). The confirmability of the findings was enhanced as clear descriptions of each stage of the research process were provided and quotations from the interview transcripts presented. During the analyses, an ongoing questioning of the abstractions and interpretations of the data took place, as well as continuous discussions within the group of authors (Paper I, II, III \& IV). Further, to ensure confirmability the data included interviews and observations together with descriptions of all parts of the research process, something which is also essential for the interpretation of family-level data (Eggenberger \& Nelms, 2007) (Paper IV).

\section{Transferability}

Transferability refers to the extent to which the findings can be transferred to and understood in another setting or group. According to van Manen (2001), the only generalisation that can be made from hermeneutical phenomenological studies is that they could never be generalised, although Dahlberg and Nyström (2001) state that the findings of phenomenological studies can be transferred to similar groups in the same context.

One relevant consideration is the sample characteristics regarding age, since the median age of being diagnosed with breast cancer is 60 years in Sweden (The National Board of Health and Welfare, 2015a). Further, less than five per cent are younger than 40 years and more than 80 per cent are over 50 years (ibid.) and the median ages in this thesis were 59.5 years (Paper I), 50 years (Paper II), 48.5 years (Paper III) and 48 years (Paper IV), respectively. This implies that the findings of this thesis might have a bearing for a large group of women with breast cancer. Moreover, it should be emphasised that the study sample does not represent women suffering from advanced breast cancer, since all the women were diagnosed with an early-stage breast cancer and treated with a curative intention.

Despite increasing globalisation, participants from ethnic minorities are underrepresented in nursing research, and Knobf et al. (2007) showed the difficulties in recruiting minorities for nursing research or any other research. A total of 22 foreign-born women were invited to participate but 12 declined (Paper II). The reasons why those 12 women declined to participate were not 
further explored, although many women claimed that they did not have the strength to talk about their situation. Thus it is open to question whether women feeling less equipped with regard to communicating their emotions and experiences would have experienced the phenomenon researched differently. Further, the majority of the participants in Paper I, III and IV were of Swedish origin, which should be taken into account when transferability is considered.

\section{Family interviews}

In study IV, the data collections were made through family interviews. There are some methodological challenges connected to the conduction of joint interviews, due to the personal bond between the participants (Taylor $\&$ de Vocht, 2011; Bjørnholt \& Farstad, 2014). While there are researchers who claim that joint interviews contribute to comprehensive data and that family members help each other to remember (Kendall et al., 2009), there are others who claim that participants might feel restrained from talking openly, or from contradicting each other or disagreeing on certain topics, and might instead give answers that are acceptable to the others (Haahr et al., 2014; Taylor \& de Vocht, 2011) and to the researcher. However, as the study (Paper IV) applied a perspective that views a family as an interconnected system, it was considered appropriate to interview families together in order to collect narrative data of mutual experiences and their multiverse realities. Defining a family as Wright and Leahey (2013) do, that is, 'the family is who they say they are', may facilitate an open climate since the participating family members were chosen by the patient, indicating that they felt comfortable talking to each other. Gathering data from several perspectives, both from the family unit and from individuals, is recommended to obtain the most comprehensive picture of a family's experience (Eggenberger \& Nelms, 2007; Åstedt-Kurki et al., 2001). 


\section{GENERAL DISCUSSION OF FINDINGS}

The overall aim of this thesis was to explore the experiences of everyday life during radiation therapy from the perspectives of the woman with breast cancer and her family, and to explore families' experiences of participating in short family health conversations (SFamHC). In this section the most prominent findings are discussed.

By studying the experiences of everyday life during radiation therapy from the women's perspective (Paper I, II \& III) as well as that of the families (Paper III), it has been possible to shed light on the needs, feelings and thoughts of the women and their families with regard to living with breast cancer. The results showed that the breast cancer diagnosis gives rise to an emotional turmoil that affects everyday life from the disclosure and all through the treatment trajectory (Paper I, II, III \& IV). Arman and Rehnsfeldt (2003) found in their metasynthesis that the lived experience and suffering of breast cancer were commonly considered a change in the life course, referred to as a transition, and seen as a time when it was important to find meaning, in order for the woman to regain integrity, balance and wholeness. Weisman and Worden (1977) described the intensified concerns about life and death experienced after a cancer diagnosis as an existential plight, a period characterised by substantial emotional distress, worries about individual health and safety, and regrets about the past. The existential concerns generated by a cancer diagnosis often give rise to a search for meaning in life and to attempts by the women to make sense of their illness and understand why they were struck with cancer (Halldórsdottir \& Hamrin, 1996; Henoch \& Danielson, 2009). It seems, however, that they experience an unmet need of support regarding existential concerns and that there is a gap in the understanding of how their existential wellbeing may be supported by health care professionals in everyday practice (Henoch \& Danielson, 2009). Further, Weisman and Worden (1977) suggest- 
ed that the existential plight lasts from the time of diagnosis and three months forward, although the findings from this thesis and evidence from longitudinal studies raise questions about whether the impact of a cancer diagnosis may require a longer period of adjustment (Bai et al., 2015; Linden et al., 2012; Waldrop et al., 2011).

The findings from this thesis further emphasise the emotional impact the breast cancer diagnosis and its treatment have on the whole family, showing that the women and their families felt that they were attending a strenuous journey, hoping and struggling to reach survival and security. Being diagnosed with breast cancer is a life-changing situation for both the woman and her family which puts them in a vulnerable life position. Every life situation can be seen as constantly changing and the individual as complex and constantly interacting with the world around her (Blumer, 1969). The importance of seeing each individual woman in her context, for example her family, is emphasised by the perspective that humans interact according to the meaning that things and situations have to them and interpret their life situation through reflections on and an understanding of others' responses to their actions. The identity of the individual, as well as her beliefs and values, are shaped and constructed in interaction with other people, and, furthermore, the meaning that humans, individually or collectively, give things and situations steers their actions (Blumer, 1969).

From the studies included in this thesis it emerged that the women and their families felt as if they were entering unknown territory where they lost track of their path, that is, of their sense of safety and their regular life and life patterns. This set them off on a quest for meaning, although they felt that they were fumbling in the dark. Their quest for meaning might be explained in the light of meaning as essential to pursuing a life seen as purposeful and goaldirected (Frankl, 1996), which can be disrupted by a stressful encounter with the environment (Lazarus \& Folkman, 1984). Negatively appraised events, such as illness, threaten global meaning, and the individual attempts to understand what has happened in order to regain a sense of control and accept or re-adjust their direction in life (Bai et al., 2015). Global meaning gives direction to a person's life, while situational meaning refers to the meaning the individual attaches to a situation, that is, the meaning experienced in the moment in everyday life (Frankl, 1996). Those who are unable to incorporate a negative event into their life situation are at greater risk of experiencing emotional distress as well as difficulties in adapting to their new circumstances 
(Bai et al., 2015), while those who are able to re-adjust may even come out stronger (Frankl, 1996).

From the studies in this thesis it also became clear that families had hoped for guidance and information from the health care professionals, and the unmet need for support and information made them fumble in the dark, in that it made them feel neglected and abandoned as well as disappointed and vulnerable. Nurses are in a key position to intervene and assist both the women and their families in their adaptation to the life changes induced by an unexpected, negative life event like breast cancer (Roy \& Andrews, 2008; Wright \& Leahey, 1994, 2013). The woman's and her family's knowledge and beliefs about breast cancer should be explored repeatedly by the nurses during the treatment trajectory in order to individualise information and support, as well as giving psychosocial support that will help the woman and her family recognise their own power and find their direction.

One way of alleviating psychological distress and existential needs as well as increasing well-being may be found in letting the women narrate their story (Bohlmeijer et al., 2008; Bohlmeijer et al., 2011). Narratives are far more than an inventory of events in chronological order; they can help a person to organise these events into an intelligible whole in which she can find meaning (Ricoeur, 1998). Experiences of connectedness to self, to others, to nature and to the significant or holy, may be expressed through narratives (Kruizinga et al., 2016). The women from Iraq expressed that their faith in God helped them to regain control, while the women from the former Yugoslavia expressed feelings of fatalism, both approaches providing meaning and facilitating the integration of the breast cancer diagnosis in their life situation (Paper II). However, neither faith nor fatalism was conveyed as particularly meaning making for the women in Paper I, III and IV. Instead they expressed the connectedness to self when participating through their breathing (BART) (Paper I), and to others, for example, their family and the nurses in the treatment team (Paper I, II, III \& IV). The meaning making through faith is less prominent in Western societies due to the growing number of nonreligious people, who rather see themselves as 'spiritual but not religious' (Erlandson, 2000; Kruizinga et al., 2016). This may suggest that health care professionals should consider offering conversations that concern spiritual and existential issues in a broader sense, including both meaning-making aspects and aspects related to faith, in order to be more inclusive and reach a wider group.

From the perspectives of both the woman and the family members, everyday life was experienced as a quest for balance and an attempt to regain con- 
trol after the received diagnosis (Paper I, II, III \& IV). The fact that the women and the family members found it hard to communicate their emotions within the family and wanted to protect each other by not talking about how they felt, led to feelings of guilt and self-reproach (Paper II, III \& IV). The women blamed themselves for bringing worry and sadness to the family and the husbands felt guilty for not being able to stay on top of the families' new life situation. The strains and stressors the parents experience when the woman in the family is diagnosed with breast cancer are also shown in previous research (Inhestern \& Bergelt, 2018; Stinesen-Kollberg et al., 2013). According to Wan et al. (2018), women diagnosed with breast cancer who have children, especially those with minor children, feel that being a mother is more important than anything else, an attitude that jeopardises their well-being and that warrants interventions and support programmes from health care professionals

Families might manage their situation better, and maladjustment in the family members might be prevented, if they are offered help to enhance and activate their own resources and coping strategies (Inhestern \& Bergelt, 2018). From the studies in this thesis it was seen that the difficulties of communicating emotions and fears gave rise to feelings of living in a divided world for both the women and their family members. The women strove to maintain a façade in front of the family, and the children were torn between their need to be near their mother and the need to live their ordinary life, spending time with their friends and without the intrusion of illness.

However, through their participation in SFamHC the women and their families found it soothing to tell their own story as well as listening to the other family members' narratives, in that it helped them verbalise their feelings and thoughts, and gave them a sense of relief (Paper IV). Family members heard each other expressing thoughts and feelings that had not been shared before, and previous research with this population of families has also shown that family members try to shield each other and experience difficulties in communicating emotions (Coyne et al., 2012).

According to the results from this thesis, women with a breast cancer diagnosis emphasise the importance of support from the nurses as well a desire for additional supportive conversations during the treatment trajectory. Further, the women and their families express a desire for supportive conversations, both individual and with the family, early in the treatment trajectory, regarding the communication of emotions and fears in connection with a breast cancer diagnosis and its treatment as well as regarding information about the treatment, its side effects and where to seek support. This further reinforces 
the need for health care professionals to have an open mind, really seeing the woman with breast cancer for whom she is, as well as her needs, and it also reinforces the need for care with a family-related as well as family-centred approach. 


\section{CONCLUSIONS}

The findings of this thesis showed that living as a family when the mother in the family is diagnosed with breast cancer means living in a challenging, rearranged and unknown reality, while struggling to regain ordinary life. This thesis affirms that a breast cancer diagnosis in the family is a strenuous experience that affects the entire family and may lead to family relationship challenges. Moreover, the study shows that the families of women with breast cancer need information and guidance from health care professionals to help them endure and cope with the distressing experience.

The families' experiences of participating in SFamHC following a breast cancer diagnosis, showed that a supportive conversation even as short as SFamHC might offer a sense of relational sharing within the family, along with a sense of not being alone, which may prevent feelings of isolation and vulnerability.

Survival, or increasing the chances of survival, is of ultimate importance for a woman with breast cancer. The women who participated in the studies included in this thesis described their life after the diagnosis as a journey for survival that started at the time of diagnosis and that they were still partaking in.

A woman needs to be acknowledged as the woman she really is, the woman behind the diagnosis, regardless of origin, in order to get support and experience increased well-being in her everyday life during radiation therapy.

The women and their families felt that their everyday life after the diagnosis sent them off into the unknown, where they strove to regain control, balanced between hope and despair, experienced their life as divided into an outer and inner world and were in need of support from each other as well as from health care professionals. 


\section{CLINICAL IMPLICATIONS}

This thesis produces knowledge that might be helpful to health care professionals caring for women with breast cancer and their families. The woman as an individual as well as her family need to be confirmed, and including the family in the caring process throughout the whole cancer trajectory can promote both individual and familial well-being. The strenuous experience that a breast cancer diagnosis and its subsequent treatment are to the woman and her family, resulting in decreased well-being, shows the need for health care professionals to provide supportive interventions in collaboration with the families in need of professional support.

Both the women and their families expressed a desire for supportive interventions early on with regard to communicating emotions and fears in connection with a breast cancer diagnosis and its treatment. There seems to be a need for both individual and family-targeted interventions, for example, narrative interventions for the woman and Short Family Health Conversations (SFamHC) for the family. Also, familial interaction patterns and family functioning ought to be considered in order to identify families at risk for poor adjustment.

The use of S-GFS as a screening tool to identify families with low selfperceived family functioning should be considered, since health care providers could use its results to elicit discussions with families, discover their needs and offer suitable interventions. 


\section{FURTHER RESEARCH}

In order to develop nursing care for women with breast cancer and their families, further research is required. There seems, not least, to be a need for further studies including women with breast cancer originating from ethnic minorities as well as their families, that is, future research should be more inclusive with regard to ethnicity and language.

Both quantitative and qualitative studies are needed to obtain more knowledge and a deeper understanding of individual family members and the family as a unit, for example, of how they affect and support each other and how they communicate and interact in order to achieve family well-being.

Evaluations of both family-related and family-centred interventions, like health-promoting conversations, could strengthen the evidence regarding what interventions are the most optimal for women and their families living with breast cancer.

In order to evaluate the effect of family-related care, there is a need for prospective longitudinal studies comparing narrative interventions, such as healthpromoting conversations or person-centred communication interventions, with standard clinical care. Further, in order to evaluate the effect of family-centred care, prospective longitudinal studies comparing family nursing interventions, such as Short Family Health Conversations (SFamHC), with standard clinical care, are also needed. As well as assessing health economic variables, possible outcomes to evaluate might include family functioning and QoL, both on a patient and a family level.

Additional evaluating research regarding whether the General Functioning Scale (S-GFS) can be used as a screening tool to identify which families might benefit from family interventions, should be further considered. 


\section{SAMMANFATTNING PÅ SVENSKA}

De bröstcancerdrabbade kvinnornas familjer riskerar att drabbas av negativa känslor i liknande omfattning som kvinnorna. De riskerar även att påverkas av den nya livssituation som följer en allvarlig diagnos, speciellt då bröstcancer ses som en potentiellt livshotande sjukdom. Det finns ett växande intresse för hur familjen upplever kvinnans bröstcancerdiagnos, även om få studier som belyser familjens upplevelser inkluderar både kvinnan och hennes familj.

Trots den stora påfrestning som en bröstcancerdiagnos i familjen kan innebära för den enskilda familjemedlemmen, finns det begränsad forskning som specifikt har undersökt familjernas upplevelse ur ett gemensamt perspektiv. Medvetenheten har ökat om vikten av att se och erkänna familjernas behov av stöd när de står inför en stor förändring i livet, såsom en allvarlig sjukdom, men trots det behandlas detta behov ofta både informellt och osystematiskt av hälso- och sjukvårdspersonal.

Tidigare forskning om familjer som har deltagit i psykosociala interventioner, såsom hälsostödjande familjesamtal, när en familjemedlem har drabbats av stroke, kronisk sjukdom, hjärt- och kärlsjukdom eller depression eller när ett barn i familjen drabbats av cancer, har visat positiva effekter för familjen. För att informationen, liksom stödet till och omhändertagandet av kvinnor med bröstcancer och deras familjer, ska vara adekvat och av bra kvalitet är det av största vikt att undersöka både kvinnornas och deras familjers upplevelser och behov i den nya livssituationen.

Avhandlingen består av fyra delstudier. Det övergripande syftet är att utforska upplevelsen av det dagliga livet under strålbehandlingsperioden ur kvinnan med bröstcancer och hennes familjs perspektiv, samt att utforska familjers upplevelse av att delta i korta hälsostödjande familjesamtal (SFamHC). Två av delstudierna, delstudie I och II, fokuserar på kvinnornas upplevelser, 
medan de andra två, delstudie III och IV, fokuserar på familjernas upplevelser, inklusive kvinnan med bröstcancer.

Den första delstudien syftade till att undersöka hur kvinnor med bröstcancer upplevde att få andningsstyrd strålbehandling (BART), samt hur de hanterade den dagliga strålbehandlingen. Intervjuer gjordes med 20 kvinnor i samband med deras sista strålbehandling. Kvinnornas upplevelser identifierades i ett övergripande tema: Att andas för livet. De upplevde andningen som ett sätt att påverka sin behandling och därmed sin egen överlevnad. Det övergripande temat kunde sedan delas upp i en huvudkategori, Att delta $i$ sin behandling, $p a$ gott och ont, samt fyra underkategorier: Att veta att man har giort något bra, Att få en extra bonus - hälsomässigt, Upplevelsen av att ha kontroll samt Att vistas $i$ en högteknologisk miljö.

I den andra delstudien intervjuades 10 kvinnor med bröstcancer, fem från Irak och fem från forna Jugoslavien. Tre av intervjuerna genomfördes med hjälp av auktoriserad tolk. Resultatet visar att kvinnorna upplevde sitt dagliga liv under strålbehandlingsperioden som att befinna sig på en smal och strapatsrik väg mot överlevnad. Deras upplevelser kunde struktureras i tre kategorier: Strategier för överlevnad, Att hålla skenet uppe samt Att bibehålla kontrollen. För att kunna utveckla individualiserade stödprogram för att hjälpa kvinnan att hantera det dagliga livet under strålbehandlingen, bör ett större fokus riktas på att se kvinnan bakom diagnosen, oavsett ursprung.

I den tredje delstudien gjordes individuella intervjuer med 19 familjemedlemmar från sex familjer. Intervjuerna genomfördes vid två olika tillfällen, i början av strålbehandlingen och två veckor efter avslutad strålbehandling. Familjemedlemmarna fick berätta om sina upplevelser av att leva som familj när en familjemedlem har drabbats av bröstcancer. Familjernas levda erfarenhet kunde beskrivas som en utmanande strävan att återfå sitt vanliga trygga liv, med hopp om att nå en trygg hamn. Familjerna upplevde att livet, såsom de kände till det, hade försvunnit och att det var som att famla i mörkret, samtidigt som de försökte eftersträva balans genom att kämpa för att hålla ihop familjen och bibehålla en positiv attityd. Det dagliga livet innebar också att de måste kämpa med känslor av skuld och tillkortakommanden på grund av svårigheter att kommunicera sina känslor. De kände sig också övergivna av hälsooch sjukvården.

Den fjärde delstudien syftade till att undersöka hur familjer upplevde att delta i korta hälsostödjande familjesamtal (SFamHC) när en familjemedlem har drabbats av bröstcancer. Nio familjer intervjuades genom familjeintervjuer, efter att ha deltagit i en serie på tre korta familjesamtal. I resultatet identi- 
fierades fyra teman: Att föra fram allt $i$ öppenhet, Att bli bekräftad som individ och som familj, Att få en oväntad insikt och Timing och sammanhang har betydelse.

Sammanfattningsvis kan resultaten från denna avhandling fördjupa förståelsen av och kunskapen om såväl hur det är att leva med bröstcancer, ur den bröstcancerdrabbade kvinnans och hennes familjs perspektiv, som vilka kvinnans och henne familjs behov är under denna tid. Deras upplevelser kan beskrivas som en resa mot överlevnad - en resa som startar i samband med att diagnosen ställs och som de fortfarande deltar i när de avslutar strålbehandlingen. Resan mot överlevnad kastar dem ut i det okända, där de strävar efter att återfå kontroll. De balanserar mellan hopp och förtvivlan. De upplever att deras liv delas i en yttre och en inre värld och de är i behov av stöd från varandra och hälso- och sjukvårdspersonalen. Ett möjligt sätt att ge stöd till kvinnorna och deras familjer kan vara att erbjuda dem att delta i korta hälsostödjande familjesamtal (SFamHC), eftersom dessa samtal ger dem en möjlighet att sätta ord på och dela sina känslor och tankar med varandra. Familjerna uttryckte att samtalen hjälpte dem att få ett avslut och komma vidare efter bröstcancerdiagnosen.

Genom att få ökad kunskap om såväl den enskilda individens som hela familjens upplevelser och behov kan omvårdnadsåtgärder utvecklas. Därmed kan välbefinnandet hos kvinnor med bröstcancer och för familjen som helhet förbättras. 


\section{ACKNOWLEDGEMENTS}

This thesis was carried out at the Department of Care Science, Faculty of Health and Society, Malmö University, and I am grateful for the opportunity to write it. I would like to express my warmest gratitude to everyone who has been a part of this work, but first and foremost to all the women and their family members who contributed with their participation. I also wish to express my sincere gratitude to the following persons:

My supervisor, Ingrid Bolmsjö, Professor at the Department of Care Science, Faculty of Health and Society, Malmö University. Thank you for believing in me throughout this journey, for your time, support and guidance.

My co-supervisor, Ewa Idvall, Professor at the Department of Care Science, Faculty of Health and Society, Malmö University. Thank you for believing in me, and for your valuable critique when reading my manuscripts and support.

My co-supervisor, Anne Wennick, Senior Lecturer at the Department of Care Science, Faculty of Health and Society, Malmö University. Thank you for believing in me, for your encouragement, good advice and your support.

My co-author, Katarina Sjövall, oncology nurse with a $\mathrm{PhD}$ and responsible for research, development and education at the Division of Hematology, Oncology and Radiation Physics. Thank you for believing in me, and for your support throughout the years.

My co-author, Vedrana Vejzovic, Senior Lecturer at the Department of Care Science, Faculty of Health and Society, Malmö University. My friend and my former fellow PhD student with whom I have shared both laughter and tears along this scientific journey. Thank you for your endless support and encouragement.

Malin Axelsson, Associate Professor at the Department of Care Science, Faculty of Health and Society, Malmö University, thank you for reading and reviewing my manuscripts. 
$\mathrm{PhD}$ students and senior lecturers at the Department of Care Science, thank you for reading, commenting on and supporting my work at seminars. Special thanks to Elisabeth Carlsson and Helena Larsson, for your thorough work reading and commenting on my thesis for my final seminar. And thank you, my fellow PhD students at the Department of Care Science, especially Jenny, Karin, Mona, Annika and Mia, for sharing this journey with me, for laughter, discussions and support.

Katarina Graah-Hagelbäck, thank you for your excellent and careful proof reading of the English, both in the thesis and Paper II, III and IV. It has been an honour and a privilege working with you.

My former colleagues at the Department of Radiation therapy, especially Ingrid Müchler, Frida Neuding and Anna-Maria Lind, thank you for your friendship throughout the years, your support and help with the inclusion of patients. Special thanks to Marie Tärnhuvud, for your support and for your excellent idea that got me started. Special thanks also to Cilla Wändel, for being a very special friend, for our discussions, your constructive criticism, your confidence in me and your unfailing support during all these years.

Thank you Monzer El-Dakkak and Vedran Boscovic, for your kindness and professional IT-support; Helena Bogazzi, for your kindness and help with practical issues regarding my thesis and dissertation; Maria Brandström, for layout support; and Carolin Lind, for reading through the popular science summary.

All of my friends, thank you for supporting me, enriching my life and making me think about other things in life than breast cancer.

Thank you to my family for being such an important part of my life. I love you! My beloved parents, Rose-Marie and Kenneth Holst, thank you for always being there and believing in me. My dearest sister Jessica, thank you for your support and not giving up on the idea of us going to a café, cinema or theatre. My brother-in-law, Pontus, thank you for making me laugh and my nephew, Benjamin, thank you for being in my life, and still letting me hug you often. My dearest 'little' brother Mattias, thank you for your support, for sharing my taste in music and numerous tapas evenings. My sister-in-law, Jenny, thank you for always being so kind and gentle.

My grandmother and grandfather, Anna-Lisa and Nils (in remembrance), thank you for your endless love and 'letting me be' the one I wanted to be.

My beloved dogs, thank you for taking me out on long walks and hikes, and always being supportive and loving me no matter what. 
Finally, but most especially, my daughter Johanna, the star on my sky, I love you to the moon and back, thank you for your endless support, your love and belief in me. My son-in-law, Caner Baleski, thank you for enriching my life in so many ways. My grandchildren, Ella and Ayla, you are most precious to me, lighting up every day of my life and reminding me of what is important in life. I love you. Last, but first in my heart, my husband and companion, Mats, thank you for always being there, listening to me and discussing this thesis and even more essential issues of our lives with infinite patience and love. I love you!

My gratitude to Stiftelsen för cancerforskning vid onkologiska kliniken Universitetssjukhuset MAS, Donationsstiftelsen av år 1982 för medicinsk forskning och utveckling, Södra Sveriges Sjuksköterskehem and Vårdakademin, for making possible the research presented in this thesis. 


\section{REFERENCES}

Ahmad, S., Fergus, K., \& McCarthy, M. (2015). Psychosocial issues experienced by young women with breast cancer: the minority group with the majority of need. Current Opinion in Supportive and Palliative Care, 9, 271-278.

Doi:10.1097/SPC.0000000000000162

Ahmad, S., Fergus, K., Shatokhina, K., \& Gardner, S. (2017). The closer 'We' are, the stronger 'I' am: the impact of couple identity on cancer coping self-efficacy. Journal of Behavioral Medicine, 40, 403-413. Doi: 10.1007/s10865-016-9803-1

Al-Badawi, R. (2002). Migration-related stress and psychosomatic consequences. International Congress Series, 1241, 271-278. Doi: 10.1016/S0531-5131(02)00649-0

Arman, M., \& Rehnsfeldt, A. (2003). The Hidden Suffering Among Breast Cancer Patients: A Qualitative Metasynthesis. Qualitative Health Research, 13(4), 510-527. Doi: $10.1177 / 1049732302250721$

Asbury, N., Lalayiannis, L., \& Walshe, A. (2014). How do I tell the children? Women's experiences of sharing information about breast cancer diagnosis and treatment. European Journal of Oncology Nursing, 18(6), 554-570. Doi:10.1016/j.ejon.2014.07.003

Ashing-Giwa, K.T., \& Lim, J.W. (2009). Examining the Impact of Socioeconomic Status and Socioecologic Stress on Physical and Mental Health Quality of Life among Breast Cancer Survivors. Oncology Nursing Forum, 36(3), 79-88. Doi: 10.1188/09.ONF.79-88

Ashing-Giwa, K.T., \& Lim, J.W. (2011). Examining Emotional Outcomes Among a Multiethnic Cohort of Breast Cancer Survivors. Oncology Nursing Forum, 38(3), 279-288.

Bai, M., Lazenby, M., Jeon, S., Dixon, J., \& McCorkle, R. (2015). Exploring the relationship between spiritual well-being and quality of life among patients newly diagnosed with advanced cancer. Palliative and Supportive Care, 3(4), 927-935.

Doi:10.1017/S1478951514000820

Beatty, L., Oxlad, M., Koczwara, B., \& Wade, T.D. (2008). The psychosocial concerns and needs of women recently diagnosed with breast cancer: a qualitative study of patient, nurse and volunteer perspectives. Health Expectations, 11, 331-342.

Doi:10.1111/j.1369-7625.2008.00512.X 
Beauchamp, T.L., \& Childress, J.F. (2013). Principles of Biomedical Ethics. New York, NY: Oxford University Press.

Bech-Jørgensen, B. (1994). Når hver dag bliver hverdag. [When every day becomes everyday]. Copenhagen, Denmark: Akademisk Forlag A/S. [In Danish].

Bech-Jørgensen, B. (2001). Alfred Schütz: Hverdagsliv og tid. [Alfred Schütz: Everyday life and time]. In Jacobsen, M.V., Carleheden, M., \& Kristiansen, S. (Eds.). [In Tradition and Renewal. A problem-oriented history of theory for sociology] (pp. 209-219). Aalborg, Denmark: Aalborg Universitetsforlag. [In Danish].

Belcher, A.J., Laurenceau, J.P. Graber, E.C., Cohen, L.H., Dasch, K.B., \& Siegel, S.D. (2011). Daily support in couples coping with early stage breast cancer: maintaining intimacy during adversity. Health Psychology, 30(6), 665-673. Doi:10.1037/a0024705

Bell, J.M. (2015). Growing the science of Family Systems Nursing: Family health intervention research focused on illness suffering and family healing. [L'avancement de la recherche sur l'intervention infirmière systémique en santé familiale: bilan]. In F. Duhamel (Ed.), La santé et la famille: Un approche systémique en soins infirmiers [Families and health: A systemic approach in nursing care] (3 ${ }^{\text {rd }}$ ed., 102-125.) Montreal, Quebec; Canada: Gaëtan Morin editeur, Chenelière Education. [In French]. English language translation available from U of C institutional Repository. PRISM: http://hdl.handle.net/1880/ 51114

Belmont, J.M. (1989). Cognitive strategies and strategic learning. The socio-instructional approach. American Psychologist, 44, 142-148. Doi:10.1037/0003-066X.44.2.142

Benktson, B.E. (1977). Existens och tro. Från Sokrates till Simone de Beauvoir. [Existence and faith. From Socrates to Simone de Beauvoir]. Lund, Sweden: Berlingska Boktryckeriet. [In Swedish].

Benzein, E. G., Hagberg, M., \& Saveman, B.I. (2008). “Being appropriately unusual”: A challenge for nurses in health-promoting conversations with families. Nursing Inquiry, 15, 106-115. Doi:10.1111/j.1440-1800.2008.00401.x

Benzein, E., Hagberg, M., \& Saveman, B.I. (Eds.). (2017). Att möta familjer inom vård och omsorg [Meeting families in health and community care]. Lund, Sweden: Studentlitteratur. [In Swedish].

Benzein, E., Olin, C., \& Persson, C. (2015). You put it all together - families' evaluation of participating in Family Health Conversations. Scandinavian Journal of Caring Sciences, 29(1), 136-44. Doi:10.1111/scs.12141

Bergum, V., \& Dossetor, J. (2005). Relational Ethics; the full Meaning of Respect. Hagerstown, MD: University Publishing Group.

Berry, J.W. (2005). Acculturation: Living successfully in two cultures. International Journal of Intercultural Relations, 29, 697-712. Doi: 10.1016/j.ijintrel.2005.07.013

Best, M., Aldridge, L., Butow, P., Olver, I., \& Webster, F. (2015). Conceptual analysis of suffering in cancer: a systematic review. Psycho-Oncology, 24(9), 977-986. Doi:10.1002/pon.3795 
Bigatti, S.M., Wagner, C.D., Lydon-Lam, J.R., Steiner, J.L., \& Miller, K.D. (2011). Depression in husbands of breast cancer patients: relationships to coping and social support. Supportive Care in Cancer, 19(4), 455-466. Doi:10.1007/s00520-010-0835-8

Bjørnholt, M., \& Farstad, G.R. (2014). ”Am I rambling?” The advantages of interviewing couples together. Qualitative Research, 14, 3-19. Doi:101177/1468794112459671

Blumer, H. (1969). Symbolic Interactionism. Perspective and Method. Berkeley and Los Angeles, CA: University of California Press.

Bohlmeijer, E.T., Westerhof, G.J., \& Emmerik-de Jong, M. (2008).The effects of integrative reminiscence on meaning in life: Results of a quasi-experimental study. Journal of Aging and Mental Health, 12(5), 639-646. Doi:10.1080/13607860802343209

Bohlmeijer, E.T., Westerhof, G.J., Randall, W., Tromp, T., \& Kenyon, G. (2011). Narrative foreclosure in later life: Preliminary considerations for a new sensitizing concept. Journal of Aging Studies, 25(4), 364-370. Doi:10.1016/j.jaging.2011.01.003

Bolejko, A., Zackrisson, S., Hagell, P., \& Wann-Hansson, C. (2013). A roller coaster of emotions and sense - coping with the perceived psychosocial consequences of a false positive screening mammography. Journal of Clinical Nursing, 23(13-14), 2053-2062.

Doi:10.1111/jocn.12426

Boyatzis, R.E. (1998). Transforming qualitative information: thematic analysis and code development. London, England: Sage.

Braun, V., \& Clarke, V. (2006). Using thematic analysis in psychology. Qualitative Research in Psychology, 3, 77-101. Doi:10.1191/1478088706qp063oa

Braun, V., Tricklebank, G., \& Clarke, V. (2013). It Shouldn't Stick Out from Your Bikini at the Beach: Meaning, Gender, and the Hairy/Hairless Body. Psychology of Women Quarterly, 1, 1-16. Doi: 10.1177/0361684313492950

Browall, M., Ahlberg, K., Karlsson, P., Danielsson, E., Persson, L.O., \& Gaston-Johansson, F. (2008). Health-related quality of life during adjuvant treatment for breast cancer among postmenopausal women. European Journal of Oncology Nursing, 12, 180-189, Doi:10.1016/j.ejon.2008.01.005

Buber, M. (1994). Between man and man. London, England: Routledge.

Burgess, E.W., \& Locke, H.J. (1953). The family: From institution to companionship. New York, NY: American Book Company.

Burnard, P. (1991). A method of analysing interview transcripts in qualitative research. Nurse Education Today, 11, 461-466.

Burnard, P. (1996). Teaching the analysis of textual data: an experiential approach. Nurse Education Today, 16(4), 278-281.

Burnard, P., Gill, P., Stewart, K., Treasure, E., \& Chadwick, B. (2008). Analysing and presenting qualitative data. British Dental Journal, 8, 429-432.

Doi:10.1038/sj.bdj.2008.292 
Bylund, A., Årestedt, K., Benzein, E., \& Persson, C. (2016). Assessment of family functioning: evaluation of the General Functioning Scale in a Swedish Bariatric Sample. Scandinavian Journal of Caring Sciences, 30(3), 614-622. Doi:10.1111/scs.12269

Caldeira, S., Timmins, F., de Carvalho, E.C., \& Vieira, M. (2016). Nursing diagnosis of 'spiritual distress' in women with breast cancer: prevalence and major defining characteristics. Cancer Nursing, 39(4), 321-327.

Doi:10.1097/NCC.0000000000000310

Campbell-Enns, H.J., \& Woodgate, R.L. (2017). The psychosocial experience of women with breast cancer across the lifespan: a systematic review. Psycho-Oncology, 26, 17111721. Doi:10.1002/pon.4281

Caplan, G. (2011). Approach to Community Mental Health. New York, NY: Routledge.

Christensen, S., Zachariae, R., Bonde Jensen, A., Væth, M., Møller, S., Ravnsbæk, J.,...von der Maase, H. (2009). Prevalence and risk of depressive symptoms 3-4 months postsurgery in a nationwide cohort study of Danish women treated for early stage breastcancer. Breast Cancer Research and Treatment, 113, 339-355. Doi:10.1007/s10549. 008-9920-9

Clarke, S. (2015). A “Child's Rights Perspective”: The Right of Children and Young People to Participate in Health Care Research. Issues in Comprehensive Pediatric Nursing, 38(3), 161-180. Doi:10.3109/01460862.2015.1042171

Clemmens, D.A. (2009). The Significance of Motherhood for Adolescents Whose Mothers Have Breast Cancer. Oncology Nursing Forum, 36(5), 571-577.

Doi:10.1188/09.ONF.571-577.

Courtier, N., Gambling, T., Enright, S., Barrett-Lee, P., Abraham, J., \& Mason, M.D. (2013). Psychological and immunological characteristics of fatigued women undergoing radiotherapy for early-stage breast cancer. Supportive Care in Cancer, 21, 173-181. Doi:1007/s00520-012-1508-6

Coyne, E., Wollin, J., \& Creedy, D.K. (2012). Exploration of the family's role and strengths after a young woman is diagnosed with breast cancer: Views of women and their family. European Journal of Oncology Nursing, 16, 124-130.

Doi:10.1016/j.ejon.2011.04.013

Coyne, E., Grafton, E., Reid, A., \& Marshall, A. (2017). Understanding family assessment in the Australian context; what are adult oncology nursing practices? Collegian, 24(2), 175-182. Doi:10.1016/j.colegn.2016.01.001

Craft, M.J,. \& Willadsen, J.A. (1992). Interventions related to family. Nursing Clinic North America, 27(2), 517-540.

Darby, S.C., Ewertz, M., McGale, P., Bennet, A.M., Blom-Goldman, U., Brønnum, D.,...Hall, P. (2013). Risk of Ischemic Heart Disease in Women after Radiotherapy for Breast Cancer. The New England Journal of Medicine, 368, 987-998. Doi:10.1056/NEJMoa1209825 
Denieffe, S., Cowman, S., \& Gooney, M. (2014). Symptoms, clusters and quality of life prior to surgery for breast cancer. Journal of Clinical Nursing, 23, 2491-2502. Doi:10.1111/jocn.12430

Denieffe, S., \& Gooney, M. (2011). A meta-synthesis of women's symptoms experience and breast cancer. European Journal of Cancer Care, 20, 424-435. Doi:10.1111/j.13652354.2010.01233.x

Dieperink, K.B., Coyne, E., Creedy, D.K., \& Östergaard, B. (2017). Family functioning and perceived support from nurses during cancer treatment among Danish and Australian patients and their families. Journal of Clinical Nursing, 27(1-2), E154-E161. Doi:10.1111/jocn.13894

DiSipio, T., Rye, S., Newman, B., \& Hayes, S. (2013). Incidence of unilateral arm lymphoedema after breast cancer: a systematic review and meta-analysis. Lancet Oncology, 14, 500-515. Doi:10.1016/S1470-2045(13)70076-7

Donalek, J.G. (2009). The family research interview. Nurse Researcher, 16(3), 21-28. Doi: 10.7748/nr2009.04.16.3.21.c6943

Donne, J. (1623/1988). Devotions upon Emergent Occasions. Meditation XVII. Cambridge, England: Cambridge University Press.

Dorval, M., Guay, S., Mondor, M., Mâsse, B., Falardeau, M., Robidoux, A.,... Maunsell, E. (2005). Couples who get closer after breast cancer: frequency and predictors in a prospective investigation. Journal of Clinical Oncology, 23(15), 3588-3596.

Doi:10.1200/JCO.2005.01.628

dos Santos Ribeiro Silva, M.C., Moules, N., Silva, L., \& Bousso, R.S. (2013). The 15minute family interview: a family health strategy tool. Revista Da Escola De Enfermagem Da U S P, 47(3), 634-639. Doi:10.1590/S0080-623420130000300016

Douglas, H.A., Hamilton, R.J., \& Grubs, R.E. (2009). The Effect of BRCA Gene Testing on Family Relationships: A Thematic Analysis of Qualitative Interviews. Journal of Genetic Counseling, 18(5), 418-435. Doi:10.1007/s10897-009-9232-1

Drabe, N., Wittman, L., Zwahlen, D., Büchi, S., \& Jenewein, J. (2013). Changes in close relationships between cancer patients and their partners. Psycho-Oncology, 22, 13441352. Doi:10.1002/pon.3144

Duggleby, W., Doel, H., Cooper, D., Thomas, R., \& Ghosh, S. (2014). The Quality of Life of Male Spouses of Women With Breast Cancer. Hope, Self-efficacy, and Perceptions of Guilt. Cancer Nursing, 37(1), E28-E35. Doi:10.1097/NCC.0b013e31827ca807.

Dukes, S. (1984). Phenomenological methodology in the human sciences. Journal of Religion and Health, 23(3), 197-203. Doi:10.1007/BF00990785

Dunn, L.B., Aouizerat, B.E., Cooper, B.A., Dodd, M., Lee, K., West, C., ... Miaskowski, C. (2012). Trajectories of anxiety in oncology patients and family caregivers during and after radiation therapy. European journal of Oncology Nursing, 16(1), 1-9.

Doi:10.1016/j.ejon.2011.01.003 
Early Breast Cancer Trialists' Collaborative Group (EBCTCG). (2011). Effect of radiotherapy after breast-conserving surgery on 10-year recurrence and 15-year breast cancer death: meta-analysis of individual patient data for 10801 women in 17 randomised trials. The Lancet, 378(9804), 1707-1716. Doi:10.1016/S0140-6736(11)61629-2

Early Breast Cancer Trialists' Collaborative Group (EBCTCG). (2014). Effect of radiotherapy after mastectomy and axillary surgery on 10-year recurrence and 20-year breast cancer mortality: meta-analysis of individual patient data for 8135 women in 22 randomised trials. The Lancet, 383(9935), 2127-2135. Doi:10.1016/S0140-6736(14)60488-8

Edwards, L., Watson, M., St. James-Roberts, I., Ashley, S., Tilney, C., Brougham, B.,... Romer, G. (2008). Adolescent's stress responses and psychological functioning when a parent has early breast cancer. Psycho-Oncology, 17, 1039-1047. Doi:10.1002/ pon. 1323

Eggenberger, S.K., \& Nelms, T.P. (2007). Family interviews as a method of family research. Journal of Advanced Nursing, 58(3), 282-292. Doi:10.1111/j.1365-2648.2007.04238.x

Engholm, G., Ferlay, J., Christensen, N., Kejs, A.M.T., Hertzum-Larsen, R., Johannesen, T.B., et al. NORDCAN: Cancer Incidence, Mortality, Prevalence and Survival in the Nordic Countries. Version 7.3: Association of the Nordic Cancer Registries. Danish Cancer Society; 2016 [updated 08.07.2016]. Available at: https://www.ancr.nu/cancerdata/nordcan-on-the-web/.

Engqvist Boman, L. Sandelin, K. Wengström, Y., \& Silén, C. (2017). Patients' learning and understanding during their breast cancer trajectory. Patient Education and Counseling, 100(5), 795-804. Doi: 10.1016/j.pec.2016.12.024.

Epstein, B.N., Baldwin, M.L., \& Bishop, S.D. (1983). The McMaster Family Assessment Device. Journal of Marital and Family Therapy, 9, 171-180.

Erlandson, S. (2000). Spiritual but Not Religious: A Call to Religious Revolution in America. Bloomington, IL: iUniverse.

EVA. Danmarks Evalueringsinstitut. (2009). Børnesperspektiver. [Child perspectives.] Available at www.eva.dk. ISBN(www)978-87-7958-509-6 [In Danish]

Ferlay, J., Soerjomataram, R., Dikshit, R., Eser, S., Mathers, C., Rebelo, M., ... Bray, F. (2015). Cancer incidence and mortality worldwide: Sources, methods and major patterns in GLOBOCAN 2012. International Journal of Cancer, 136(5), E359-E386. Doi: $10.1002 /$ ijc. 29210

Fisher, C., \& O'Connor, M. (2012). "Motherhood” in the Context of Living With Breast Cancer. Cancer Nursing, 35(2), 157-163. Doi: 10.1097/NCC.0b013e31821cadde

Fitzmaurice C, Allen C, Barber RM, Barregard L, Bhutta ZA, Brenner H, et al. The Global Burden of Disease Cancer Collaboration (2017). Global, Regional, and National Cancer Incidence, Mortality, Years of Life Lost, Years Lived With Disability, and DisabilityAdjusted Life-years for 32 Cancer Groups, 1990 to 2015: A Systematic Analysis for the Global Burden of Disease Study. JAMA Oncology, 3(4), 524-548. Doi:10.1001/jamaonco.2016.5688 
Fletcher, K.A., Lewis, F.M., \& Haberman, M.R. (2010). Cancer-related concerns of spouses of women with breast cancer. Psycho-Oncology, 19, 1094-1101. Doi:10.1002/ pon. 1665

Forouzanfar, M.H., Foreman, K.J., Delossantos, A.M., Lozano, R., Lopez, A.D., Murray, C.J.L. \& Naghavi, M. (2011). Breast and cervical cancer in 187 countries between 1980 and 2010: a systematic analysis. The Lancet, 378(9801), 1461-1484.

Doi:10.1016/S0140-6736(11)61351-2

Frankl, V.E. (1996). Livet måste ha en mening. Erfarenheter i koncentrationslägren. Logoterapins grunder. [Man's search for meaning. Experiences from Nazi death camps.

An introduction to logotherapy]. Viborg, Denmark: Natur och Kultur. [In Swedish].

Gadamer, H.G. (2004). Truth and method (2nd ed.). New York: Continuum.

Gatta, G., Trama, A., \& Capocaccia, R. (2013). Variations in Cancer Survival and Patterns of Care Across Europe: Roles of Wealth and Health-Care Organization. Journal of the National Cancer Institute Monographs, 46, 79-87.

Doi:10.1093/jncimonographs/lgt004 Gemma Gatta

Glaser, A.W., Fraser, L.K., Corner, J., Feltbower, R., Morris, A.J.A., Hartwell, G., \& Richards, M. (2013). Patient-reported outcomes of cancer survivors in England 1-5 years after diagnosis: a cross-sectional survey. BMJ Open 2013, 3, e002317.

Doi: 10.1136/bmjopen-2012-002317

Haahr, A., Norlyk, A., \& Hall, E.O. (2014). Ethical challenges embedded in qualitative research interviews with close relatives. Nursing Ethics, 21, 6-15.

Doi:10.1177/0969733013486370

Halkett, G.K.B., Kristjanson, L.J., \& Lobb, E. (2008). 'If we get too close to your bones they'll go brittle: Women's initial fears about radiotherapy for early breast cancer. Psycho-Oncology, 17, 877-884. Doi:10.1002/pon.1298

Halkett, G.K.B., Kristjanson, L.J., Lobb, E., Little, J., Shaw, T., Taylor, M., \& Spry, N. (2012). Information needs and preferences of women as they proceed through radiotherapy for breast cancer. Patient Education and Counselling, 86(3), 396-404.

Doi: 10.1016/j.pec.2011.05.010

Halldórsdottir, S., \& Hamrin, E. (1996). Experiencing existential changes: the lived experience of having cancer. Cancer Nursing; 19(1), 29-36.

Harmon-Hanson, S.M., Gedaly-Duff, V. \& Rowe Kaakinen, J. (2005). Family Health Care Nursing. Theory, Practice and Research (3rd ed.). Philadelphia, PA: F.A. Davis Company.

Hartrick G.A., \& Lindsey A.E. (1995). The lived experience of family: a contextual approach to family nursing practice. Journal of Family Nursing, 1, 148-170. Doi: $10.1177 / 107484079500100203$ 
Henoch, I., \& Danielson, E. (2009). Existential concerns among patients with cancer and interventions to meet them: an integrative literature review. Psycho-Oncology, 18, 225 236. Doi: $10.1002 /$ pon.1424

Hewitt, M., Greenfield, S., \& Stovall, E. (2006). (Eds). From Cancer Patient to Cancer Survivor: Lost in Translation. Institute of Medicine and National Research Council of the National Academies. Washington, D.C.: National Academy of Sciences.

Holmberg, E., Holm, L.E., Lundell, M., Mattsson, A., Wallgren, A., \& Karlsson, P. (2001). Excess breast cancer risk and the role of parity, age at first childbirth and exposure to radiation in infancy. British Journal of Cancer, 85(3), 362-366.

Doi: 10.1054/bjoc.2001.1868

Huang, X., O'Connor, M., \& Lee, S. (2014). School-aged and adolescent children's experience when a parent has non-terminal cancer: a systematic review and meta-synthesis of qualitative studies. Psycho-Oncology, 23, 493-506. Doi: 10.1002/pon.3457

Ingvarsdotter, K., Johnsdotter, S. \& Östman, M. (2010). Lost in interpretation: The use of interpreters in the research on mental health illness. International Journal of Social Psychiatry, 58(1), 34-40. Doi: 10.1177/0020764010382693

Inhestern, L., Haller, A.C., Wlodarczyk, O., \& Bergelt, C. (2016). Psychosocial Interventions for Families with Parental Cancer and Barriers and Facilitators to Implementation and Use - A Systematic Review. PloS ONE, 11(6), e0156967. Doi:10.1371/journal.pone. 0156967

Inhestern, L. \& Bergelt, C. (2018). When a mother has cancer: strains and resources of affected families from the mother's and father's perspective - a qualitative study. BMC Women's Health, 18, 72. Doi: 10.1186/s12905-018-0562-8

John, K., Becker, K., \& Mattejat, F. (2013). Impact of family-oriented rehabilitation and prevention: an inpatient program for mothers with breast cancer and their children. Psycho-Oncology, 22, 2684-2692. Doi:10.1002/pon.3329

Kapborg, I., \& Berterö, C. (2000). Using an interpreter in qualitative interviews: does it threaten validity? Nursing Inquiry, 9(1), 52-56. Doi:10.1046/j.1440-1800.2002.00127.x

Kendall, M., Murray, S.A., Carduff, E., Worth, A., Harris, F., Lloyd, A.,...Sheikh, A. (2009). Use of multiperspective qualitative interviews to understand patients' and carers' beliefs, experiences, and needs. The British Medical Journal, 339, b4122.

Doi:10.1136/bmj.b4122

Kernan, W.D., \& Lepore, S.J. (2009). Searching for and making meaning after breast cancer: Prevalence, patterns, and negative affect. Social Science \& Medicine, 68, 11761182. Doi:10.1016/j.socscimed.2008.12.038

Knobf, M.T., Juarez, G., Lee, S.Y.K., Sun, V., Sun, Y., \& Haozous, E. (2007). Challenges and Strategies in Recruitment of Ethnically Diverse Populations for Cancer Nursing Research. Oncology Nursing Forum, 34(6), 1187-1194. Doi:10.1188/07.ONF.1187-1194 
Koch, L., Bertram, H., Eberle, A., Holleczek, B., Schmid-Höpfner, S., Waldman, A.,... Arndt, V. (2014). Fear of recurrence in long-term breast cancer survivors - still an issue. Results on prevalence, determinants, and the association with quality of life and depression from the Cancer Survivorship - a multi-regional population-based study. PsychoOncology, 23(5), 547-554. Doi:10.1002/pon.3452

Korreman, S.S., Juhler-Nöttrup, T., Fredberg Persson, G., Navrsted Pedersen, A., Enmark, M., Nyström, \& Specht, L. (2008). The role of image guidance in respiratory gated radiotherapy. Acta Oncologica, 47(7), 1390-1396.

Doi: 10.1080/02841860802282786

Kraemer, L.M., Stanton, A.L., Meyerowitz, B.E., Rowland, J.H., \& Ganz, P.A. (2011). A longitudinal examination of couples' coping strategies as predictors of adjustment to breast cancer. Journal of Family Psychology, 25(6), 963-972. Doi: 10.1037/a0025551

Krattenmacher, T., Kühne, F., Ernst, J., Bergelt, C., Romer, G., \& Möller, B. (2012). Parental cancer: Factors associated with children's psychosocial adjustment - a systematic review. Journal of Psychosomatic Research, 72, 344-356.

Doi:10.1016/j.psychores.2012.01.011.

Kruizinga, R., Hartog, I.D., Jacobs, M., Daams, J.G., Scherer-Roth, M., Schilderman, J.B.A.M., Sprangers, M.A.G., \& Laarhoven, H.W.M. (2016). The effect of spiritual interventions addressing existential themes using a narrative approach on quality of life of cancer patients: a systematic review and meta-analysis. Psycho-Oncology, 25(3), 253265. Doi:10.1002/pon.3910

Kwan, M. L., Ergas, I. J., Somkin, C. P., Quesenberry, C. P. Jr, Neugut, A. L., Hershman, D. L... Kushi, L.H. (2010). Quality of life of women recently diagnosed with invasive breast cancer: the Pathways Study. Breast Cancer Research and Treatment, 123, 50724. Doi: 10.1007/s10549-010-0764-8.

Kwok, C., \& White, K. (2014). Perceived information needs and social support of ChineseAustralian breast cancer survivors. Supportive Care in Cancer, 22(10): 2651-2659.

Doi: $10.1007 / \mathrm{s} 00520-014-2252-\mathrm{x}$

Lazarus, R.S., \& Folkman, S. (1984). Stress, appraisal, and coping. New York, NY: Springer Publishing.

Lebel, S., Beattie, S., Arés, I., \& Bielajew, C. (2013). Young and Worried: Age and Fear of Recurrence in Breast Cancer Survivors. Health Psychology, 32(6), 695-705. Doi: $10.1037 / \mathrm{a} 0030186$

Levine, E.G., Yoo, G.J., \& Aviv, C. (2017). Predictors of Quality of Life among Ethnically Diverse Breast Cancer Survivors. Applied Research Quality Life, 12, 1-16.

Doi: $10.1007 / \mathrm{s} 11482-016-9447-\mathrm{x}$

Lewis, F.M., Fletcher, K.A., Cochrane, B.B., \& Fann, J.R. (2008). Predictors of Depressed Mood in Spouses of Women With Breast Cancer. Journal of Clinical Oncology, 26(8), 1289-1295. Doi: 10.1200/JCO.2007.12.7159 
Lewis, F., Merckaert, I., Liénard, A., Libert, Y., Etienne, A.M., Reynaert, C.,... Razavi, D. (2014). Anxiety and its time courses during radiotherapy for non-metastatic breast cancer: A longitudinal study. Radiotherapy and Oncology, 111, 276-280.

Doi:10.1016/j.radonc.2014.03.016

Lim, C.C., Devi, M.K., \& Ang, E. (2011). Anxiety in women with breast cancer undergoing treatment: a systematic review. International Journal of Evidence-Based Healthcare, 9, 25-235. Doi:10.1111/j.1744-1609.2011.00221.x

Lincoln, Y.S., \& Guba, E.G. (1985). Naturalistic Inquiry. Beverly Hills, CA: Sage Publications.

Linden, W., Vodermaier, A., MacKenzie, R., \& Greig, D. (2012). Anxiety and depression after cancer diagnosis: Prevalence rates by cancer type, gender, and age. Journal of Affective Disorder, 10(2-3), 343-351. Doi:10.1016/j.jad.2012.03.025

Lipsett, A., Barrett, S., Haruna, F., Mustian, K., \& O'Donovan, A. (2017). The impact of exercise during adjuvant radiotherapy for breast cancer on fatigue and quality of life: A systematic review and meta-analysis. The Breast, 32, 144-155.

Doi:10.1016/j.breast.2017.02.002

Lopez-Class, M., Perret-Gentil, M., Kreling, B., Caicedo, L., Mandelblatt, J., \& Graves, K.D.(2011). Quality of life among immigrant Latina breast cancer survivors: realities of culture and enhancing cancer care. Journal of Cancer Education, 26(4), 724-733. Doi:10.1007/s13187-011-0249-4.

Lopez, V., Copp, G., \& Molassiotis, A. (2012). Male Caregivers of Patients With Breast and Gynecologic Cancer: Experiences From Caring for Their Spouses and Partners. Cancer Nursing, 35(6), 402-410. Doi: 10.1097/NCC.0b013e318231daf0

Lou, Z., Li, Y., Yang, Y., Wang, L., \& Yang, J. (2015). Affects of Anxiety and Depression on Health-Related Quality of Life among Patients with Benign Breast Lumps Diagnosed via Ultrasonography in China. International. Journal of Environmental Research and Public Health, 12(9), 10587-10601. Doi:10.3390/ijerph120910587

Luckett, T., Goldstein, D., Butow, P. N., Gebski, V., Aldridge, L. J., McGrane, J.... King, M.T. (2011). Psychological morbidity and quality of life of ethnic minority patients with cancer: a systematic review and meta-analysis. Lancet Oncology, 12, 1240-1248. Doi:10.1016/S1470-2045(11)70212-1

Marmot, M.G., Altman, D.G., Cameron, D.A., Dewar, J.A., Thompson, S.G., \& Wilcox, M. (2013). The benefits and harms of breast cancer screening: an independent review. British journal of cancer, 108(11), 2205-2240. Doi:10.1038/bjc.2013.177

Marshall, B., Cardon, P., Poddar, A., \& Fontenot, R. (2013). Does sample size matter in qualitative research?: A review of qualitative interviews in IS research. Journal of Computer Information Systems, 54(1),11-22. Doi:10.1080/08874417.2013.11645667

Mason, M. (2010). Sample Size and Saturation in PhD Studies Using Qualitative Interviews. Qualitative Social Research, 11(3). Doi: 10.17169/fqs-11.3.1428.

Available at http://nbn-resolving.de/urn:nbn:de:0114-fqs100387. 
Mehnert, A., Berg, P., Heinrich, G., \& Herschbach, P. (2009). Fear of cancer progression and cancer-related intrusive cognitions in breast cancer survivors. Psycho-Oncology, 18, 1273-1280. Doi:10.1002/pon. 1481

Mischler, E.G. (1996). Research Interviewing: Context and Narrative. Cambridge, MA: Harvard University Press.

Mor, V., Malin, M., \& Allen, S. (1994). Age differences in the psychosocial problems encountered by breast cancer patients. Journal of the National Cancer Institute, 16,191197.

Morse, J.M. (2000). Determining Sample Size. Qualitative Health Research, 10(1), 3-5.

Nemoto, K., Oguchi, M., Nakajima, M., Kozuka, T., Nose, T., \& Yamashita, T. (2009). Cardiac-sparing radiotherapy for the left breast cancer with deep-breath holding. Japanese Journal of Radiology 27(7), 259-263. Doi:10.1007/s11604-0090336-1

Njeh, C.F. (2008). Tumor delineation: The weakest link in the search for accuracy in radiotherapy. Journal of Medical Physics, 33(4), 136-140. Doi: 10.4103/0971-6203.44472

Northouse, L., Kershaw, T., Mood, D., \& Schafenacker, A. (2005). Effects of a family intervention on the quality of life of women with recurrent breast cancer and their family caregivers. Psycho-Oncology, 14(6), 478-491. Doi:10.1002/pon.871

Northouse, L., Williams, A.L., Given, B., \& McCorkle, R. (2012). Psychosocial Care for Family Caregivers of Patients With Cancer. Journal of Clinical Oncology, 30, 12271234. Doi:10.1200/JCO.2011.39.5798

Nyström, M., \& Dahlberg, K. (2001). Pre-understanding and openness - a relationship without hope? Scandinavian Journal of Caring Sciences, 15(4), 339-346.

Doi:10.1046/j.1471-6712.2001.00043.x

Patel-Kerai, G., Harcourt, D., Rumsey, N., Naqvi, N., \& White, P. (2017). The psychosocial experiences of breast cancer amongst Black, South Asian and White survivors: do differences exist between ethnic groups? Psycho-Oncology, 26, 515-522.

Doi: 10.1002/pon.4187

Paterson, C.L., Lengacher, C.A., Donovan, K.A., Kip, K.E., \& Tofthagen, C.S. (2016). Body Image in Younger Breast Cancer Survivors. A Systematic Review. Cancer Nursing, 39(1), E39-E58. Doi:10.1097/NCC.0000000000000251

Patton, M.Q. (2002). Qualitative research \& evaluation methods. (3rd ed.). London, England: Sage.

Peate, M., Maiser, B., Hickey, M., \& Friedlander, M. (2009). The fertility-related concerns, needs and preferences of younger women with breast cancer: a systematic review. Breast Cancer Research and Treatment, 116, 215-223. Doi: 10.1007/s10549-009-0401-6 
Piaget, J. (1972). Intellectual evolution from adolescence to adulthood. Human Development, 157-164.

http://www.fondationjeanpiaget.ch/fjp/site/textes/VE/JP70_Evolut_Intellect_ Adoles_Adulte.pdf Retrieved [2018-04-10].

Polit, D.F., \& Beck, C.T. (2017). Nursing Research. Generating and Assessing Evidence for Nursing Practice (10th ed.). China: Wolters Kluwer.

Raque-Bogdan, T.L., Hoffman, M.A., Ginter, A.C., Piontkowski, S., Schexnayder, K., \& White, R. (2015). The work life and career development of young breast cancer survivors. Journal of Counseling Psychology, 62(4), 655-669.

RCC. Regional Cancer Center in Collaboration. (2018). Nationellt vårdprogram bröstcancer. [National breast cancer care programme]. Available at:

https://www.cancercentrum.se/samverkan/cancerdiagnoser/brost/vardprogram/. [In Swedish].

Remmers, H., Holtgräwe, M., \& Pinkert, C. (2010). Stress and nursing care needs of women with breast cancer during primary treatment: A qualitative study. European Journal of Oncology Nursing, 14, 11-16. Doi:10.1016/j.ejon.2009.07.002

Ricoeur, P. (1988). Time and Narrative, Vol. 3. Chicago, IL: University of Chicago Press.

Robbins, M.L., Mehl, M.R., Smith, H.L., \& Weihs, K.L. (2013). Linguistic indicators of patient, couple, and family adjustment following breast cancer. Psycho-Oncology, 22, 1501-1508. Doi: 10.1002/pon.3161

Robbins, M.L., Lopez, A.M., Weihs, K.L., \& Mehl, M.R. (2014). Cancer Conversations in Context: Naturalistic Observation of Couples Coping with Breast Cancer. Journal of Family Psychology, 28(3), 380-390. Doi:10.1037/a0036458.

Rowe-Kaakinen, J., Padgett Coehlo, D., Steele, R., Tabacco, A., \& Harmon Hanson, S.M. (2015). Family Health Care Nursing. Theory, practice, and Research (5th ed.). Philadelphia, PA: F.A. Davis Company.

Roy, C., \& Andrews, H.A. (2008). The Roy Adaptation Model. (3rd ed.). Stanford, CT: Appleton \& Lange.

Ruddy, K.J., Gelber, S.I., Tamimi, R.M., Ginsburg, E.S., Schapira, L., Come, S.E.,...Partridge, A.H. (2014). Prospective study of fertility concerns and preservation strategies in young women with breast cancer. Journal of Clinical Oncology, 32(11), 1151-1156. Doi: 10.1200/JCO.2013.52.8877

Sammarco, A. (2003). Quality of life among older survivors of breast cancer. Cancer Nursing, 26(6),431-438.

Salvo, N., Barnes, E., Van Draanen, J., Stacey, E., Mitera, G. Breen, D.,...DeAngelis, C. (2010). Prophylaxis and management of acute radiation-induced skin reactions: a systematic review of literature. Current Oncology, 17, 94-112. Available at: https://www. ncbi.nlm.nih.gov/pmc/articles/PMC2913836/ 
Schmid-Büchi, S., Halfens, R.J.G., Dassen, T., \& van den Borne, B. (2011). Psychosocial problems and needs of post treatment patients with breast cancer and their relatives. European Journal of Oncology Nursing, 15, 260-266. Doi:10.1016/j.ejon.2009.11.001

Schnur, J.B, Ouellette, S.C., Bovbjerg, D.H., \& Montgomery, G.H. (2009). Breast Cancer Patients' Experience of External-Beam Radiotherapy. Qualitative Health Research, 19(5), 668-676. Doi:10.1177/1049732309334097

Schnur, J.B., Love, B., Scheckner, B.L., Green, S., Wernicke, A.G., \& Montgomery, G.H. (2011a). A systematic review of patient-rated measures of radio dermatitis in breast cancer radiotherapy. American Journal of Clinical Oncology, 34, 529-536.

Doi:10.1097/COC.0b013e3181e84b36

Schnur, J.B, Ouellette, S.C., DiLorenzo, T.A., Green, S., \& Montgomery, G.H. (2011b). A Qualitative Analysis of Acute Skin Toxicity among Breast Cancer Radiotherapy Patients. Psycho-Oncology, 20(3), 260-268. Doi:10.1002/pon.1734.

Schubart, J.R., Emerich, M., Farnan, M., Smith, J.S., Kauffman, G.L., \& Kass, R.B. (2014). Screening for Psychological Distress in Surgical Breast Cancer Patients. Annals of Surgical Oncology, 10, 3348-3353. Doi:10.1245/s10434-014-3919-8

Segrin, C., \& Badger, T.A. (2014). Psychological and physical distress are interdependent in breast cancer survivors and their partners. Psychology, Health and Medicine, 19(6), 716-723. Doi.org/10.1080/13548506.2013.871304

Semple, C.J., \& McCance, T. (2010). Experience of parents with head and neck cancer who are caring for young children. Journal of Advanced Nursing, 66, 1280-1290. Doi:10.1111/j.1365-2648.2001.05311.x.

Senkus, E., Kyriakides, S., Ohno, S., Penault-Llorca, F., Poortmans, P., Rutgers, E., et al. on behalf of the ESMO Guidelines Committee. (2015). Primary breast cancer: ESMO Clinical Practice Guidelines for diagnosis, treatment and follow-up. Annals of Oncology, 26 (Supplement 5), 8-30. Doi:10.1093/annonc/mdv298

Snöbohm, C., Friedrichsen, M., \& Heiwe, S. (2010). Experiencing one's body after a diagnosis of cancer-a phenomenological study of young adults. Psycho-Oncology, 19(8), 863-869. Doi:10.1002/pon.1632

Sprung, B.R., Janotha, B.L., \& Steckel, A.J. (2011). The lived experience of breast cancer patients and couple distress. Journal of the American Association of Nurse Practitioners, 23(11), 619-627. Doi: 10.1111/j.1745-7599.2011.00653.x

Statistics Sweden (SCB). (2018). Folkmängd efter region, födelseregion och år. [Population by region, birth region and year].

http://www.statistikdatabasen.scb.se/pxweb/sv/ssd/START_BE_BE0101__BE0101E

/InrUtrFoddaRegAlKon/table/tableViewLayout1/?rxid=107af7c9-a23a-402a-abab-cd 4e5c1c402a. [In Swedish].

Stinesen-Kollberg, K.M., Thorsteinsdottir, T., Wilderäng, U., \& Steineck, G. (2013). "Worry about one's own children, psychological wellbeing, and interest in psychosocial interventions". Psycho-Oncology, 22(9), 2117-2123. Doi: 10.1002/pon.3266 
Taylor, B. \& de Vocht, H. (2011). Interviewing Separately or as Couples? Considerations of Authenticity of Method. Qualitative Health Research, 21, 1576-1587.

Doi:101177/1049732311415288

Temple, B. (2002). Crossed wires: Interpreters, translators, and bilingual workers in crosslanguage research. Qualitative Health Research, 12(6), 844-854.

Doi:10.1177/104973230201200610

Thastum, M., Munch-Hansen, A., Wiell, A., \& Romer, G. (2006). Evaluation of a Focused Short-term Preventive Counselling Project for Families with a Parent with Cancer. Clinical Child Psychology and Psychiatry, 11(4), 529-542. Doi:10.1177/1359104506067875

The National Board of Health and Welfare (2015a). Cancer statistic. [Cancer statistics 2015]. http://www.socialstyrelsen.se/statistik/statistikdatabas/cancer [In Swedish].

The National Board of Health and Welfare (2015b). Bröstcancer, screening med mammografi.[Breastcancer, screening with mammography]. http://www.socialstyrelsen. se/riktlinjer/nationellascreeningprogram/brostcancer-screeningmedmammog [In Swedish].

United Nations High Commissioner for Refugees, UNHCR. The UN Refugee Agency. http://unhcr.org/cgi-bin/texis/vtx/home. Retrieved [2018-01-28].

van Ee, B., Smits, C., Honkoop, A., Kamper, A, Slaets, J., \& Hagedoorn, M. (2017). Open Wounds and Healed Scars: A Qualitative Study of Elderly Women's Experiences With Breast Cancer. Cancer Nursing, E1-E9. Doi:10.1097/NCC.0000000000000575

van Manen, M. (2001). Researching Lived Experience: Human Science for an Action Sensitive Pedagogy (2nd ed.). Ontario, Canada: Althouse press.

Vannatta, K., Grollman, J.A., Noll, R.B., \& Gerhardt, C.A. (2008). Impact of maternal breast cancer on the peer interactions of children at school. Psycho-Oncology, 17(3), 252-259. Doi: 10.1002/pon.1232

Vannatta, K., Ramsey, R.R., Noll, R.B., \& Gerhardt, C.A. (2010). Associations of Child Adjustment With Parent and Family Functioning: Comparison of Families of Women With and Without Breast Cancer. Journal of Developmental \& Behavioral Pediatrics, 31(1), 9-16. Doi: 10.1097/DBP.0b013e3181c82a44

Voltelen, B., Konradsen, H., \& Østergaard, B. (2017). Ethical considerations when conducting joint interviews with close relatives or family: an integrative review. Scandinavian Journal of Caring Science, 32(2), 515-526. Doi:10.1111/scs.12535

Vrinten, C., Wardle, J., \& Marlow, L.A.W. (2016). Cancer fear and fatalism among ethnic minority women in the United Kingdom. British Journal of Cancer, 114, 597-604. Doi:10.1038/bjc.2016.15

Wagner, C.D., Bigatti, S.M., \& Storniolo, A.M. (2006). Quality of life of husbands of women with breast cancer. Psycho-Oncology, 15, 109-120. Doi:10.1002/pon.928

Wagner, C., Tanmoy Das, L., Bigatti, S.M., \& Storniolo, A.M. (2011). Characterizing Burden, Caregiving Benefits, and Psychological Distress of Husbands of Breast Cancer Patients During Treatment and Beyond. Cancer Nursing, 34(4), E21-E30.

Doi:10.1097/NCC.0b013e31820251f5 
Waldrop, D.P., O'Connor, T.L., \& Trabold, N. (2011). 'Waiting for the Other Shoe to Drop:' Distress and Coping During and After Treatment for Breast Cancer. Journal of Psychosocial Oncology, 29, 450-473. Doi:10.1080/07347332.2011.582638

Wallin, A.M., \& Ahlström, G. (2006). Cross-cultural interview studies using interpreters: systematic literature review. Journal of Advanced Nursing, 55(6), 723-735.

Doi:10.1111/j.1365-2648.2006.03963.x

Wan, C., Arés, I., Gareau, A., Collins, K.A., Lebel, S., \& Bielajew, C. (2018). Motherhood and well-being in young breast cancer survivors. Breast Cancer Management. (Epub ahead of print). Doi:10.2217/bmt-2017-0015

Weisman, A. D., \& Worden, J. W. (1977). The existential plight in cancer: Significance of the first 100 days. International Journal of Psychiatry in Medicine, 7(1), 1-15. Doi:0.2190/UQ2G-UGV1-3PPC-6387

Whall, A.L. (1986). The Family as the Unit of Care in Nursing: A Historical Review. Public Health Care Nursing, 3(4), 240-249. Doi:10.1111/j.1525-1446.1986.tb00495.x

Williams, F., \& Jeanetta, S.C. (2015). Lived experiences of breast cancer survivors after diagnosis, treatment and beyond: qualitative study. Health Expectations, 19, 631-642.

Doi:10.1111/hex.12372

World Cancer Research Fund International. (2017). Continuous Update Project Report: Diet, Nutrition, Physical Activity and Breast Cancer: World Cancer Research Fund International/American Institute for Cancer Research; 2017. Available from: https://www.wcrf.org/sites/default/files/Breast-Cancer-2017-Report.pdf

World Medical Association. WMA. (2013). Declaration of Helsinki - Ethical Principles for Medical Research Involving Human Subjects. www.wma.net/en/30publications/ 10policies/b3/

Retrieved [2018-03-03].

Wright, L.M., \& Bell, J. (2009). Beliefs and illness. A model for healing. Calgary: 4th Floor Press.

Wright, L.M., \& Leahey, M., (1994). Calgary Family Intervention Model: One way to think about change. Journal of Marital and Family Therapy, 20, 381-395. Doi:10.1111/j.1752-0606.1994.tb00128.x

Wright, L.M., \& Leahey, M. (1999). Maximizing Time, Minimizing suffering: The 15Minute (or less) Family Interview. Journal of Family Nursing, 5(3), 259-273.

Wright, L.M., \& Leahey, M., 2013. Nurses and Families. A Guide to Family Assessment and Intervention. (6th ed.). Philadelphia, PA: F.A. Davis Company.

Wright, L., Watson, W., \& Bell, J. (2002). Familjefokuserad omvårdnad. [Beliefs: The heart of healing in families]. Lund, Sweden: Studentlitteratur. [In Swedish].

Zebrack, B.J., Yi, J., Petersen, L., \& Ganz, P.A. (2008). The impact of cancer and quality of life for long-term survivors. Psycho-Oncology, 17, 891-900. Doi:10.1002/pon.1300 
Zhang, J., Zhou, Y., Feng, Z., Xu, Y., \& Zeng, G. (2018). Longitudinal Trends in Anxiety, Depression, and Quality of Life During Different Intermittent Periods of Adjuvant Breast Cancer Chemotherapy. Cancer Nursing, 41(1), 62-68. Doi: 10.1097/ NCC.0000000000000451

Åstedt-Kurki, P., Paavilainen, E., \& Lehti, K. (2001). Methodological issues in interviewing families in family nursing research. Journal of Advanced Nursing, 35(2), 288-293. Doi:10.1046/j.1365-2648.2001.01845.x

Östlund, U., \& Persson, C. (2014). Examining Family Responses to Family Systems Nursing Interventions: An Integrative Review. Journal of Family Nursing, 20(3), 259-286. Doi:10.1177/1074840714542962

Øye, C., Øvre Sørensen, N., \& Glasdam, S. (2016). Qualitative research ethics on the spot: Not only on the desktop. Nursing Ethics, 23(4), 455-464.

Doi:10.1177/0969733014567203 


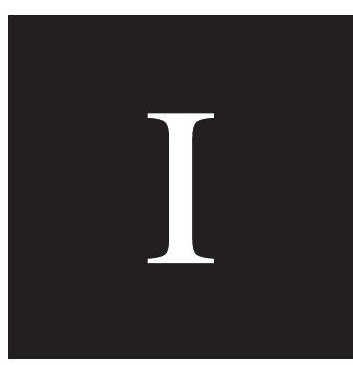





\title{
The breath of life - Womens' experiences of breathing adapted radiation therapy
}

\author{
A. Holst-Hansson ${ }^{\text {a,b,c, },}$, K. Sjövall ${ }^{c, d}$, E. Idvall ${ }^{a}$, I. Bolmsjö ${ }^{a}$ \\ ${ }^{a}$ Department of Health and Society, Malmö University, S-205 06 Malmö, Sweden \\ ${ }^{\mathrm{b}}$ Department of Radiation Therapy, Skảnes University Hospital, Jan Waldenströms gata 28, S-205 02 Malmö, Sweden \\ 'Department of Oncology, Skänes University Hospital, S-221 85 Lund, Sweden \\ d Department of Health Sciences, Lund University, S-221 00 Lund, Sweden
}

\begin{tabular}{|c|c|}
\hline & A B $S T R A C T$ \\
\hline $\begin{array}{l}\text { Keywords: } \\
\text { Breathing adapted radiation therapy } \\
\text { BART } \\
\text { Breast cancer } \\
\text { Women } \\
\text { Experience } \\
\text { Participation } \\
\text { Survival } \\
\text { Life } \\
\text { Control }\end{array}$ & $\begin{array}{l}\text { Purpose: To describe and analyze how women with breast cancer experience breathing adapted radiation } \\
\text { therapy (BART) and to explore how women manage daily radiation therapy. } \\
\text { Method: Individual interviews were conducted with } 20 \text { women treated with BART for breast cancer } \\
\text { concerning their perception of radiation therapy. The transcribed interviews were analyzed using } \\
\text { qualitative content analysis. } \\
\text { Results: 'The breath of life' was the overall theme, as the women experienced the breathing as a way in } \\
\text { which to influence their treatment and thus their survival. 'Participating in one's treatment, for good or } \\
\text { ill', was the main category with four subcategories, 'Knowing one has done something good', 'Getting an } \\
\text { extra bonus - healthwise', 'The experience of being in control' and 'Being in a high-technology envi- } \\
\text { ronment'. The breathing technique became the strategy by which they could manage their treatment and } \\
\text { gave them a sense of participation which led to a feeling of being in control. The women also felt that } \\
\text { breathing benefited their health both mentally and physically. The high-technology environment was } \\
\text { experienced as both hopeful and frightening. } \\
\text { Conclusion: Survival or increasing the chances of survival, are of ultimate importance for a woman with } \\
\text { breast cancer. BART requires commitment from the women, which was perceived as offering them an } \\
\text { opportunity to participate in their own treatment, for their survival. Increasing the women's possibilities } \\
\text { to participate in their treatment benefits their health and welfare during an otherwise turbulent time } \\
\text { and allow the rehabilitation process to start during treatment. }\end{array}$ \\
\hline
\end{tabular}

(c) 2012 Elsevier Ltd. All rights reserved.

\section{Introduction}

The global incidence of breast cancer among women has almost tripled during the past 30 years and in 2010 approximately 1643000 women around the world were diagnosed with breast cancer (Forouzanfar et al., 2011). In Sweden 7000 women annually are diagnosed with breast cancer, which means that between 15 and 30 women are diagnosed with breast cancer every day (National Board of Health and Welfare, 2009). In approximately $80 \%$ of these women breast cancer treatment is supplemented with radiotherapy (SBU, 2003). Most radiation treatments are given as a supplement after surgery, to reduce the risk of local recurrence

\footnotetext{
* Corresponding author. Department of Health and Society, Malmö University, Jan Waldenströms gata 25, S-205 06 Malmö, Sweden. Tel.: +46 4066 57278; fax: +46 406658100.

E-mail addresses: Annette.Holst.Hansson@mah.se (A. Holst-Hansson), Katarina.Sjovall@skane.se (K. Sjövall), Ewa.Idvall@mah.se (E. Idvall), Ingrid.Bolmsjo@ mah.se (I. Bolmsjö).
}

1462-3889/\$ - see front matter $\odot 2012$ Elsevier Ltd. All rights reserved. http://dx.doi.org/10.1016/j.ejon.2012.10.003 but breast cancer-specific survival rates also improve after irradiation (Clarke et al., 2005; Vinh-Hung and Verschraegen, 2004; Whelan et al., 2000).

Although the survival rates are improving, breast cancer diagnosis often results in a wide range of feelings, such as anxiety and concern (Dabrowski et al., 2007; Deshields et al., 2007; Jemal et al., 2004; Wengström et al., 2001). Studies (Schnur et al., 2009; Halkett et al., 2008) also reveal that women who receive radiotherapy for breast cancer experience great anxiety before, during and after treatment. The women have concerns about what radiotherapy is, how it works, how they can manage their therapy and what life will be like for them in the future (Halkett et al., 2008). The radiation therapy period usually lasts between 16 and 25 days, but can sometimes continue for up to 33 days, and the daily treatment time is about $20 \mathrm{~min}$.

Increased cardiovascular-related morbidity and mortality have been reported in women who have received radiation therapy for breast cancer on the left side (Hooning et al., 2007; Schultz-Hector and Trott, 2007). Radiation therapy technology has improved 
gradually over the years but the risk of heart damage is difficult to estimate as it can take 10-20 years before the damage to the heart occurs. A recent study by McGale et al. (2011) which examined the incidence of heart disease in 35000 women who received radiation therapy for breast cancer between 1976 and 2006 showed a greater incidence of heart disease in women irradiated for breast cancer on the left side compared to those irradiated for breast cancer on the right side. The risk of heart attack as well as angina, pericarditis, and valvular heart disease increased when radiation therapy for breast cancer was given on the left side (McGale et al., 2011). In another study (Roychoudhuri et al., 2007) cardiovascular mortality was shown to be $25 \%$ higher 15 years after irradiation for breast cancer on the left side than for irradiation on the right side.

A new radiation therapy technology, breathing adapted radiation therapy (BART), has been introduced to reduce the risk of cardiac events since, especially for women treated for breast cancer on the left side, it is difficult to avoid irradiation of the heart (Nemoto et al., 2009). BART was first introduced in Japan in the late 1990s (Kubo and Hill, 1996; Minohara et al., 2000) and was further developed in the USA for breast cancer treatment (Lu et al., 2000).

One important factor to consider in radiotherapy for breast cancer is that the chest moves when the patient breathes. BART, also known as "gating", uses this movement to its advantage (Korreman et al., 2008)

When the patient takes deep breaths the chest rises further away from the heart. The radiation is given only when the patient is in the right respiratory phase, in other words, when the chest is as far from the heart as possible (Korreman et al., 2008). Patients are trained to breathe deeply, regularly and reproducible in order to optimize the gain from the treatment. A recorded voice guides the patient's breathing rhythm and the times for exhalation and inhalation can be varied to suit the individual (Korreman et al., 2008; Nemoto et al., 2009). The recorded voice is played at every session. Performing the preparatory reference imaging computer tomography (CT) in the same breathing phase, treatment planning can be done in the image data to match the patient's position during radiotherapy. A camera in the CT room as well as in the treatment room monitor the patient's respiration and register the breathing pattern by means of infrared light reflected by a marker box, placed at the same spot on the patient's sternum on every occasion. A breathing graph can be seen on the computer screen in the control room, monitored by the nurses, and is displayed in real time. The radiation interval, a so-called "gating window", is also highlighted on the computer screen, the extent of this window is set individually for each patient. The irradiation takes place when the marker box on the patient's chest, and thus the patient's chest, is within the limits of the gating window (Nemoto et al., 2009).

In the meeting before radiation therapy is started all the medical staff have a real opportunity to assess women's understanding and concerns about the impending treatment, to listen to their fears and provide reassurance about the treatment and the management of any adverse events (Halkett et al., 2012). Marbach and Griffie (2011) reveal that cancer patients want the medical staff to convey clear expectations of treatment plans and provide educational information about the disease and its treatment as well as support.

No previous articles have been found which deal with how patients experience and manage BART. BART is more time consuming than conventional radiotherapy. The longer treatment time combined with the active participation required from the patient suggests that patients need strategies to cope with the daily treatment. Knowledge is needed concerning how patients experience BART in order to help them achieve a good level of compliance. The purpose of this study was to describe and analyze how women with breast cancer experience breathing adapted radiation therapy and to explore how they manage the daily radiation therapy.

\section{Methods}

Design

A qualitative approach comprising interviews was used to conduct this study.

\section{Sample}

Interviews were conducted in spring 2010 with 20 women, from the southern part of Sweden, with breast cancer on the left side receiving curative breathing adapted radiation therapy including the breast/chest wall and lymph nodes. The inclusion criteria were: female, 18 years of age or older and able to speak and write Swedish. The sample was strategically chosen to include a variety of ages and stages of breast cancer.

The mean age for the sample was 51.6 years (range 32-69, median 59.5). All the participants except one were native Swedish speakers. The majority of the women were married or lived with a partner. Both employment status and the level of education varied. Seven of the women had children living at home. Four women who were asked declined to participate and no reason was required or given.

\section{Interviews}

The study was conducted in interview form with two open questions in which the author asked respondents to describe their experience of receiving breathing adapted radiation therapy and how they managed their daily radiation treatment. The interviews began with a clarification of the purpose of the study. As the interview was conducted in the form of conversation, questions were asked to clarify or further describe the informants' answers but also to confirm understanding (Kvale, 2007; Rapley, 2001). Follow-up questions focused on points the interviewees brought up concerning BART and their experiences. The scheduled interviews were conducted at places chosen by the respondents and took place in connection with their radiation treatment. All the interviews were conducted by the first author in a secluded room in the hospital. The interviews were taped and transcribed verbatim and lasted between 25 and 90 min (median $45 \mathrm{~min}$ ).

\section{Data analysis}

The interviews were transcribed verbatim and qualitative content analysis was applied to the resulting text. The analysis was conducted in Swedish. This method of analysis was chosen as the amount of text is comprehensive and needs to be organized and structured with the aim of interpreting the underlying meaning of the informants' stories (Polit and Beck, 2006; Burnard, 1991). The method of analysis followed that of qualitative content analysis inspired by Burnard $(1991,1996)$, Burnard et al. (2008). The interview texts were read and reread several times by the first author to get an idea of what both the text and the interview were about, in order to gain a deeper understanding of the meaning of the text. This can be compared with trying to understand the informant's situation (Burnard, 1991).

Then the interview text was examined by the first author focusing on the experience of undergoing breathing adapted radiation therapy with special attention to how the informants managed their daily treatment. Repeated interpretations of the complete transcript of all the interviews were made at separate abstraction levels (Burnard, 1991, 1996). Major or significant statements were emphasized, and the similarities and differences noted. Secondly, the transcript was divided into meaning units and 
those with similar content were collected and coded. The coded units were sorted and then grouped into subcategories which, through re-interpretation were then reduced to fewer higher-order categories (Burnard et al., 2008)

An overall theme emerged with a deeper meaning as the final step of the process of analysis. Finally, one overall theme remained one category with four subcategories.

The first author conducted the analysis, but to establish confirmability, all the text was read and reread by the second author and identified subcategories, category and overall theme were discussed within the team of authors. The fourth author also conducted an independent analysis of the text from five interviews to increase the conformability.

\section{Ethical considerations}

This study was approved by the Health Sciences Ethics Committee Lund University (VEN 98-09). Subject numbers were assigned to the women (I) to ensure confidentiality. Informed consent was obtained both verbally and in writing. The informants, who were not dependent on the researchers in any way, were informed that participating was voluntary and could be the terminated at any time without any consequences. They were also assured that their confidentiality would be respected throughout the research process. Written information about the study was given by the primary nurse in the second half of the treatment period, and verbal information was given by the first author to those who were interested to in participating. A course of treatment comprises $16-33$ sessions and interviews were carried out during one of the last five days of treatment. The women were given a week to consider whether or not they wanted to participate in the study. If they were willing they gave written notice in a sealed envelope to the primary nurse, who in turn forwarded it to the first author.

\section{Rigor}

The first, second and third author's are all nurses. The great expertise and knowledge of the fourth author lies in health science and ethics. The second, third and fourth authors contributed their scientific knowledge.

Efforts were made throughout the research process to evaluate the trustworthiness, namely credibility, transferability, dependability, confirmability of the study (Lincoln and Guba, 1985). Trustworthiness concerns the researcher's competence as an interviewer (Kvale, 2007), knowledge of the context of the study and the informants, and the depth of the interview dialogue (Rapley, 2001). Efforts to strengthen credibility and dependability were made during the interview by attempts to achieve a mutual understanding of the meaning of questions and responses and inviting the informants to deepen their narratives. The first author tried to direct the informants' narratives towards their experience of breathing adapted radiation therapy, and strove to empower informants by tuning in, letting them tell their stories and making coherent sense of their experiences (Mishler, 1986).

Trustworthiness is enhanced when the verbatim transcripts are presented in the form of quotations in the finished work strengthening the results. However, the quotes are translated from Swedish, which can contribute a threat to credibility. To reduce this threat, the quotations have been translated and back-translated with the help of a translator outside the research team.

Validation and confirmation (Malterud, 2001) were ensured by engaging the informant in a dialogue in which follow-up questions were asked to elicit the informant's genuine opinion. The trustworthiness of the open questions were enhanced by thorough discussion between the first and second authors, both engaged in the oncological treatment.

As a study's credibility is increased if it is transferable to other individuals in similar contexts; demographic data are presented in the work. The credibility of the study was enhanced by having the first author conducting all the interviews in the same manner, posing similar follow-up questions to all informants.

Lively continuing discussions among the authors led to the highlighting of differences and eventually consensus. This can be seen as enhancing conformability since the third and fourth authors are not engaged in oncological treatment. The different pre-understandings of the authors, arising from their differing clinical experiences, were discussed.

\section{Results}

Qualitative content analysis identified one overall theme, one category and four subcategories. The final theme was - 'The breath of life'; the category was: 'Participating in one's treatment for good or ill', the subcategories were: 'Knowing one has done something good', 'Getting an extra bonus - healthwise', 'The experience of being in control' and 'Being in a high-technology environment'.

\section{The breath of life}

Breathing was seen as guide and therefore also as a strategy throughout the treatment.

Being able to manage one's breathing gave one a strong and positive sense of control but a sense of concern could also be experienced when the breathing technique did not function optimally and the nurses had to guide the women through breathing and treatment.

Breathing to live was expressed in many ways; by breathing well the women felt that they were making a positive contribution to their treatment and were thus increasing their chances of survival. The hopes and thoughts connected with radiation therapy revolved largely around the fact that it was their life that was at stake, and the feeling of being able to influence their treatment was mostly experienced as positive, but sometimes also as a burden. There was a willingness to fight for their lives and to accept the treatment offered whatever sacrifice and effort had to be made. The breathing technique that might affect their survival was considered not only as an acceptable effort, but also as a strategy for coping with their radiotherapy.

"You want to make an effort - and do it right, you have the voice to follow and you breathe as it tells you and the time goes more quickly when you follow the voice's instructions, you concentrate on breathing and you think about why you are there, you know, you hope it won't come back and you want it to go well" I12

\section{Participating in one's treatment for good or ill}

Participating in one's treatment for good or ill was the category that emerged from the interview text. This participation could be experienced as a sense of achieving something good and of gaining a health bonus but could also be experienced as a sense of losing control. Being in a high technology environment of a radiotherapy department was perceived as both hopeful and frightening. Participating in their own treatment was perceived by the women as having an opportunity to maintain control over their lives (Table 1).

\section{Knowing that one has done something good}

Being involved meant being explicitly invited by physicians and nurses to join the treatment team. The invitation was perceived as 
Table 1

Examples of meaning units, codes, subcategories, category and theme.

\begin{tabular}{|c|c|c|c|c|}
\hline Meaning units & $\begin{array}{l}\text { (What is it about/meaning) } \\
\text { Examples of condensed codes }\end{array}$ & Sub-category & Category & Theme \\
\hline $\begin{array}{l}\text { "I've only listened to the voice and been focused } \\
\text { on breathing" (I 1) }\end{array}$ & $\begin{array}{l}\text { Focused on the breathing } \\
\text { Want to achieve the optimal }\end{array}$ & $\begin{array}{l}\text { Knowing one has done } \\
\text { something good }\end{array}$ & \multirow[t]{8}{*}{$\begin{array}{l}\text { Participating in one's } \\
\text { treatment for good or ill }\end{array}$} & \multirow[t]{8}{*}{$\begin{array}{l}\text { The breath } \\
\text { for life }\end{array}$} \\
\hline $\begin{array}{l}\text { "one wants to put some effort and do it right } \\
\text { and you can, you just follow the voice" (I 19) }\end{array}$ & $\begin{array}{l}\text { treatment } \\
\text { Follows the voice }\end{array}$ & & & \\
\hline $\begin{array}{l}\text { "So when you are there, and deep breathing like } \\
\text { that, well, then you become very calm " (I 7) }\end{array}$ & Calm by breathing & $\begin{array}{l}\text { Gaining an extra bonus, } \\
\text { healthwise }\end{array}$ & & \\
\hline $\begin{array}{l}\text { "I know of course that breathing has helped me, } \\
\text { because I was so wheezy when I first came to } \\
\text { you" (I 2) }\end{array}$ & $\begin{array}{l}\text { Experiences an improved } \\
\text { condition }\end{array}$ & & & \\
\hline $\begin{array}{l}\text { "you may think that you breathe just the same } \\
\text { but, you know, you really don't" (I20) }\end{array}$ & Unsure of breathing technique & $\begin{array}{l}\text { The experience of being } \\
\text { in control }\end{array}$ & & \\
\hline $\begin{array}{l}\text { "yes but I wanted to also say that it's nice that it's } \\
\text { the same team, I meet every time, to have } \\
\text { continuity" (I16) }\end{array}$ & Continuity provides security & & & \\
\hline $\begin{array}{l}\text { "it is the whole environment, you know, in the } \\
\text { waiting room and everywhere, that no one sees, } \\
\text { I'm alone and so, there are machines and I am on } \\
\text { my own" (I8) }\end{array}$ & $\begin{array}{l}\text { Frightening environment } \\
\text { Exposed }\end{array}$ & $\begin{array}{l}\text { Being in a high-technology } \\
\text { environment }\end{array}$ & & \\
\hline $\begin{array}{l}\text { "everything that comes up, have to be tested and it's } \\
\text { a good thing that you're offered this new } \\
\text { radiotherapy" (I3) }\end{array}$ & $\begin{array}{l}\text { Hopeful with new } \\
\text { technology }\end{array}$ & & & \\
\hline
\end{tabular}

providing a sense of context and security. Participation gave the women an opportunity to influence their radiation treatment, which seemed to bring them satisfaction.

"and just the fact that you can do something yourself, be part of the treatment, I think that is important" I16

Breathing could be seen as training and a job; breathing became a commitment and they experienced satisfaction when they felt that they had handled their job well. When the women performed well, it served as a tonic for their self esteem and they felt that they had begun their rehabilitation, they were a step closer to "normal life", life as they were used to living it.

The women felt that the recorded voice helped them to handle their breathing well and guided them throughout treatment; they waited for the voice to begin. The breathing they did perform was a collaborative effort between the voice and themselves and was perceived as a job they had done in their own interests.

"You know, you think about it all the time, you lie there and wait for the voice to start" I 1

The more detailed information and explanation of the breathing graph meant that the women had a better understanding of how to breathe and why. The women emphasized the importance of understanding where the radiation ended up in their body. The possibility to be involved gave them the opportunity to discuss the information they had been given, which in turn led to the women deepening their knowledge and hence their understanding of their treatment. Understanding how breathing affected their treatment and what their bodies looked like on the inside were felt to be clarifying factors that helped the women to do a good job.

Getting an extra bonus - healthwise

Being involved through their breathing was experienced as bringing additional health benefits, both mental and physical. Focusing on the breathing made the treatment seem less stressful, and the feeling of being in a meditative state during the breathing felt helpful and soothing. The women thought that the active breathing pushed other stressful thoughts aside and that their focus during treatment was on breathing. Focusing on their breathing therefore meant that the treatment time functioned as a respite from the turbulence in their lives. The women said that their participation through breathing became both therapeutic and pedagogic; the focus on the breathing became "a treatment in the treatment".

"Focusing on that you are in it all the time and I really used that, I thought it's almost a bit meditative, when I was lying there, I thought I', lying here and I can't do anything else, so I saw it as a treatment in the treatment" I 11

The women felt that their performance and stamina increased during the treatment period, and linked this to the breathing during radiation therapy. The women already knew that breathing properly is important for health and well-being.

"I could hardly walk down the corridor, but it's getting better and better and I think it's connected with this breathing" I2

There was concern among the women that they would not be able to proceed throughout their treatment if they had not used the breathing technique. A strong belief existed that everyone who receives radiation therapy or other treatments could benefit from having some sort of breathing schedule to allow them to better focus on and manage their treatment.

"so I actually believe that it would have been difficult just to lie there and not do the breathing, I think I would have used some breathing strategy of my own" I 10

\section{The experience of being in control}

The experience of being in control represented both resources and barriers. The strong and positive sense of control linked to being able to manage their breathing could be replaced by feelings of panic and anxiety when the breathing was not so successful. The experience of being able to deliver adequate breathing strengthened the feeling of having the possibility to influence their treatment. There was a fear of influencing their treatment negatively. When the breathing was not so successful it made the women felt as they were excluded from participation and was expressed as giving rise to a feeling of disorientation and vulnerability.

The women felt that close contact with their primary nurse and the nurses in the treatment team was a resource that helped them 
experience control. They were able to feel more in control of their situation when they felt the security and support provided by the nurses in their treatment team. The women felt that they were allowed to be themselves in the radiotherapy department, and give expression to everything that is included in the crisis response, such as sorrow and despair but also joy. This security made it possible for them to begin to try to regain control over their lives. To be treated as an individual and not just a patient was seen to be very important for having a feeling of control.

"Yes, but it's also a sort of security, there's been safety in being here, it's sort of nice to be here, even those times when I just lost it" I13

The fact that staff did not all guide the women in the same way, by using the same terms and being consistent regarding their breathing, was said to be both detrimental to proper breathing and a stressor. This stress factor was experienced particularly by the younger women as it stayed with them, made them anxious about their performance and worried about the next day's treatment. These women simultaneously felt they had lost all control.

"you do what the teacher says, it can be really different, and I feel it's a bit like that here, perhaps I'm completely wrong, but there have been eight of you around me" I11

The younger women experienced a sense of losing control, as they felt that sometimes they wanted to talk to the nurses in peace and quiet but pointed out that not all patients had the strength to ask questions so the staff needed to be alert and sensitive to their situation and mood. They expressed a wish that the staff had offered a "half-time" conversation during the radiation period. They believed that such a conversation offering the possibility of getting more information regarding the treatment and its side effects might have helped them to feel more in control.

"even if you ask, and well it's not always like that, you feel that you, like, you know, don't always want to let it all out, you don't always feel that it's the right time... it's perhaps not completely wrong, that you'll do it later, that you perhaps don't want to then, just say no thanks, perhaps even just at half-way that you offer a little extra there" I 1

Being in a high-technology environment

The high-technology environment that a radiotherapy department is, was perceived as both hopeful and a source of security. It stood for new, improved treatment technologies, as well as being frightening because it was an unknown environment. The women felt that time passed quickly both regarding the daily treatment and the total treatment period. The short treatment time was seen as a major benefit and had helped the women to cope with their situation.

The informants thought it was a good thing that treatment technology had been developed and were grateful that they had been offered the new technology. They felt that they had been offered an extra procedure and had got the feeling that they had received the best available treatment. The women believed strongly that the technology had been developed to save more lives, which was perceived as very hopeful. They became familiar with the various sounds of the machine and the treatment procedure itself, which gave them a sense of security.

The unknown environment with its high technology gave rise to unpleasant associations with a spacecraft. Some of the women felt that the linear accelerator (radiotherapy machine) could be large and terrifying as it moved around them, and they associated the treatment situation with a space environment and science fiction. Being treated by something invisible and yet so powerful in a high technology environment could be experienced as frightening and unreal. "then it's an unpleasant situation, it's also a scary place, so, partly that one is laying there in that big outer space place, all exposed," I 9

Lying alone under the radiotherapy machine could also be experienced as very unpleasant. The women saw themselves as vulnerable and abandoned, although they also noted that they knew they could be seen by staff at all times.

"and it feels like you're not really there, anywhere even if I know that you are, yes, I think that, even if you say you can see me and such, I am anyway still alone" I 9

Going downstairs to a dark basement to get advanced radiation therapy was perceived as both stressful and unpleasant. The cramped and rundown basement environment was felt to be a strange counterpoint to the high-technology care. That there was free coffee and other hot drinks, and a TV to watch while they waited was seen as a good thing.

"no and then I think the whole area is awful, it really is. Refurnish it, do something about it" I 4

\section{Discussion}

The feeling the women had that the breathing became their strategy for dealing with their treatment, permeated in all the interviews. Focusing on breathing pushed away second thoughts and ideas during the radiation treatment, and so the breathing was perceived as positive and became a respite from concerns and demands. Drageset et al. (2010) describe similar phenomena in their study of how women with breast cancer manage the time between diagnosis and surgery by focusing on something else and thereby distancing themselves from the situation.

The breathing technique also meant that they could participate in their treatment. The feeling of taking part in their treatment was essential for the women and gave them a sense of control. The breathing adapted radiation therapy allowed the women to feel a sense of control and that, through their participation, they became part of the treatment team. Sainio et al. (2001) found that the highest level of satisfaction with care and treatment is shown by patients who take an active part in their care. Sainio and Lauri (2003) also pointed out that staff should work to improve cancer patients' opportunities to participate in the care and decisionmaking so that it is possible for those patients who wish to do so to be involved.

The need to receive personalized and extended information in order to understand how radiotherapy works, its purpose and effect shows the need for an individualized care. Studies (Berg and Danielson, 2007; Henderson, 2003) have shown that patients who do not feel involved experience feelings of vulnerability and thus do not dare, or have the strength, to ask the questions they really need about their care. These studies spoke instead of indifference, lack of respect from health professionals and fear. Suhonen et al. (2010) examined nurses' views on individualized care and found that nurses felt that they were supportive of the patients' individual well-being and that in their care they actually saw the person as an individual. Those most in favor of individualized care were nurses in psychiatric care. The study also shows, however, that healthcare organizations and working environments need to be evaluated since they may play a role in the extent in which the care really is individualized.

The women felt that their nurse and the nurses in the treatment team supported them which made them feel safe and in control. This safety meant that the women felt they were seen and accepted as the individuals they are, which in turn meant that they dared to 
participate more actively in their treatment and rehabilitation. In their study, Halkett and Kristjanson (2007) described how patients are linked to the nurses at the radiotherapy department, get to know "their" nurses, and thus feel that they can both receive information and discuss their situation. Having the opportunity to both get information and support and also security and comfort when needed was a vital element for the involvement of patients in their treatment. Larsson et al. (2011) showed that being regarded as a person, engaged through information and acknowledged as competent stimulated patient participation.

Meeting the patient in the situation she is in means that the nurse needs to invite the patient to participate and engage in an educational dialogue. In the dialogue the nurse needs to discover what the patient wants to know and also make an assessment of her needs. In this way the nurse allows the patient to follow the reasoning, and to be a part of a learning experience and the patient can more easily find a sense of dignity, participation, confidence and a belief in her own knowledge and skill (Friberg et al., 2007).

\section{Clinical implications}

The most important thing for a woman with breast cancer is to survive or to increase her chances of survival. In order to achieve this goal women are motivated to work together with the medical staff. The breathing adapted radiation therapy requires a commitment on the part of the women which they experienced as an opportunity to participate in their own treatment for survival. Breathing and participation were also felt to provide mental and physical health benefits and constituted a strategy for managing the daily radiotherapy. Enhancing the possibilities for women to participate in their treatment benefits health and welfare during an otherwise turbulent time and can mean that the rehabilitation process can start during treatment.

\section{Conflict of interest statement}

All authors of this study certify that there are no conflicts of interest to declare.

\section{References}

Berg, L., Danielson, E., 2007. Patients' and nurses' experiences of the caring relationship in hospital: an aware striving for trust. Scandinavian Journal of Science 21 (4), 500-506.

21 (4), 500-506.
Burnard, P., 1991. A method of analyzing interview transcripts in qualitative urnard, P., 1991. A method of analyzing inter
research. Nurse Education Today 11, 461-466.

research. Nurse Education Today $11,461-466$.
Burnard, P., 1996. Teaching the analysis of textual data: an experiential approach. Nurse Education Today 16 (4), 278-281.

Burnard, P., Gill, P., Stewart, K., Treasure, E., Chadwick, B., 2008. Analysing and presenting qualitative data. British Dental Journal 204, 429-432.

Clarke, M., Collins, R., Darby, S., Davies, C., Elphinstone, P., Evans, E., et al., 2005. Effects of radiotherapy and of differences in the extent of surgery for early breast cancer on local recurrence and 15-year survival: an overview of the randomised trials. Lancet 366, 2087-2106.

Dabrowski, M., Boucher, K., Ward, J.H., Lovell, M.M., Sandre, A., Bloch, J., et al., 2007. Clinical experience with the NCCN distress thermometer in breast cance patients. Journal of the National Comprehensive Cancer Network 5 (1), 104-111.

Deshields, T.L., Reschke, A., Walker, M.S., Brewer, A., Taylor, M., 2007. Psychological status at time of diagnosis and patients' ratings of cosmesis following radiation therapy for breast cancer. Journal of Psychosocial Oncology 25, 103-116.

Drageset, S., Lindström, T.C., Underlid, K., 2010. Coping with breast cancer: between diagnosis and surgery. Journal of Advanced Nursing 66 (1), 149-158.

Forouzanfar, M.H., Foreman, K.J., Delossantos, A.M., Lozano, R., Lopez, A.D., Murray, C.J.L., et al., 2011. Breast and cervical cancer in 187 countries worldwide between 1980 and 2010: a systematic analysis. The Lancet 378 (9801), 1461-1484.

Friberg, F., Pilhammar Andersson, E., Bengtsson, J., 2007. Pedagogical encounters between nurses and patients in a medical ward - a field study. International Journal of Nursing Studies 44 (4), 534-544.
Halkett, G.K.B., Kristjanson, L.J., 2007. Patients' perspective on the role of the radiotherapists. Patient Education and Counseling 69 (7), 6-83

Halkett, G.K.B., Kristjansson, L., Lobb, E.A., 2008. 'If we get too close to your bones they'll go brittle': women's initial fears about radiotherapy for early breast cancer. Psychooncology 17 (9), 877-884.

Halkett, G.K.B., Kristjanson, L.J., Lobb, E., Little, J., Shaw, T., Taylor, M., et al., 2012. Information needs and preferences of women as they proceed through radiotherapy for breast cancer. Patient Education and Counseling 86 (3), 396-404.

Henderson, S., 2003. Power imbalance between nurses and patient: a potential inhibitor of partnership in care. Journal of Clinical Nursing 12 (4), 501-508.

Hooning, M.J., Botma, A., Aleman, B.M.P., Baaijens, M.H.A., Bartelink, H., Klijn, J.G.M. et al., 2007. Long-term risk of cardiovascular disease in 10-year survivors of et al., 2007. Long-term risk of cardiovascular disease in 10-year survivor
breast cancer. Journal of the National Cancer Institute 99 (5), 365-375.

Jemal, A. Clegg, L.X., Ward, E. Ries, L.A.G., Wu, X., Jamison, P.M., et al., 2004. Annual mal, A., Clegg, L.X., Ward, E., Ries, L.A.G., Wu, X., Jamison, P.M., et al., 2004. Annual
report to the nation on the status of cancer, 1975-2001, with a special feature report to the nation on the status of cancer
regarding survival. Cancer 101 (1), 3-27.

Korreman, S.S., Juhler-Nöttrup, T., Fredberg Persson, G., Navrsted Pedersen, A Enmark, M., Nyström, H., et al., 2008. The role of image guidance in respiratory
(a) Enmark, M., Nyström, H., et al., 2008. The role of image
gated radiotherapy. Acta Oncologica 47 (7), 1390-1396.

Kubo, H.D., Hill, B.C., 1996. Respiration gated radiotherapy treatment: a technical study. Physics in Medicine and Biology 41 (1), 83-91.

Kvale, S., 2007. Doing Interviews. Sage Publications Inc., California.

Larsson, I.E., Sahlsten, M.J.M., Segesten, K., Plos, K.A.E., 2011. Patients' participation of nurses behavior that influence patient participation in nursing care: a critical incident theory. Nursing Research and Practice. http://dx.doi.org/10.1155/2011/ 534060.

Lincoln, Y.S., Guba, E.G., 1985. Naturalistic Inquiry. Sage Publications Inc., London.

Lu, H.M., Cash, E., Chen, M.H., Chin, L., Manning, W.J., Harris, J., et al., 2000. Reduction of cardiac volume in left-breast treatment fields by respiratory maneuvers: a CT study. International Journal of Radiation Oncology Biology Physics 47 (4), 895-904

Malterud, K., 2001. Qualitative research: standards, challenges and guidelines. Lancet 358, 483-488.

Marbach, T.J., Griffie, J., 2011. Patient preferences concerning treatment plans, survivorship care plans, education and support services. Oncology Nursing Forum 38 (3), 335-342.

McGale, P., Darby, S.C., Hall, P., Adolfsson, J., Bengtsson, N.O., Bennet, A.M., et al., 2011. Incidence of heart disease in 35,000 women treated with radiotherapy for

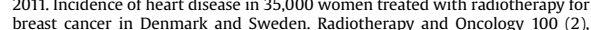
$167-175$.

Minohara, S., Kanai, T., Endo, M., Noda, K., Kanazawa, M., 2000. Respiratory gated irradiation system for heavy-ion radiotherapy. International Journal of Radiation Oncology Biology Physics 47 (4), 1097-1103.

Mishler, E.G., 1986. Research Interviewing: Context and Narrative. Harvard University Press, Cambridge, MA.

National Board of Health and Welfare, 2009. Cancerförekomst i Sverige 2009 Stockholm. www.socialstyrelsen.se/Lists/Artikelkatalog/Attachments/18204 2010-12-17 [2012-05-20].

Nemoto, K., Oguchi, M., Nakajima, M., Kozuka, T., Nose, T., Yamashita, T., 2009 Cardiac-sparing radiotherapy for the left breast cancer with deep-breath holding. Japanese Journal of Radiology 27 (7), 259-263.

Polit, D.F., Beck, C.T., 2006. Essentials of Nursing Research: Methods, Appraisal and Utilization, sixth ed. Lippincott, Philadelphia.

Rapley, T.J., 2001. The art (fulness) of open-ended interviewing: some considerations on analysing interviews. Qualitative Research 1 (3), 303-323.

Roychoudhuri, R., Robinson, D., Putcha, V., Cuzick, J., Darby, S., Møller, H., 2007. Increased cardiovascular mortality more than fifteen years after radiotherapy for breast cancer: a population-based study. BMC Cancer 7, 9.

Sainio, C., Lauri, S., 2003. Cancer patients' decision-making regarding treatment and nursing care. Journal of Advanced Nursing 41 (3), 250-260.
nowio,

Sainio, C., Lauri, S., Eriksson, E., 2001. Cancer patients' views and experiences of participation in care and decision making. Nursing Ethics 8 (2), 97-113.
.

participation in care and decision making. Nursing Ethics 8 (2), 97-113.
SBU, 2003. Strálbehandling vid cancer. Statens beredning för utvärdering av medicinska metoder $162 / 1$ och $162 / 2$. Göteborg.

Schnur, J.B., Oulette, S.C., Bovbjerg, D., Montgomery, G., 2009. Breast cancer patients experience of external-beam radiotherapy. Qualitative Health Research 19 (5), 668-676.

Schultz-Hector, S., Trott, K.R., 2007. Radiation-induced cardiovascular diseases: is the epidemiologic evidence compatible with the radiobiologic data? International Journal of Radiation Oncology Biology Physics 67 (1), 10-18.

Suhonen, R., Gustafsson, M.L., Katajisto, J., Välimäki, M., Leino-Kilpi, H., 2010. Nurses perception of individualized care. Journal of Advanced Nursing 66 (5), 1035 1046.

Vinh-Hung, V., Verschraegen, C., 2004. Breast-conserving surgery with or without radiotherapy: pooled-analysis for risks of ipsilateral breast tumor recurrence and mortality. Journal of the National Cancer Institute 96 (2), 115-121.

Wengström, Y., Häggmark, C., Forsberg, C., 2001. Coping with radiation therapy: strategies used by women with breast cancer. Cancer Nursing 24 (4), 264-271

Whelan, T.J., Julian, J., Wright, J., Jadad, A.R., Levine, M.L., 2000. Does loco regional radiation therapy improve survival in breast cancer? A meta-analysis. Journal of Clinical Oncology 18 (6), 1220-1229. 
II 



\title{
The narrow treatment road to survival: Everyday life perspectives of women with breast cancer from Iraq and the former Yugoslavia undergoing radiation therapy in Sweden
}

\author{
A. Holst-Hansson RN, MSc, PhD Student ${ }^{1,2}$ (D) | E. Idvall RN, PhD, Professor ${ }^{1}$ | I. Bolmsjö \\ BTh, Professor ${ }^{1}$ | A. Wennick RN, RSCN, PhD ${ }^{1}$
}

\author{
${ }^{1}$ Faculty of Health and Society, Department \\ of Care Science, Malmö University, Malmö, \\ Sweden \\ ${ }^{2}$ Department of Hematology, Oncology and \\ Radiophysics, Skåne University Hospital, Lund, \\ Sweden \\ Correspondence \\ Annette Holst-Hansson, Faculty of Health and \\ Society, Department of Care Sciences, Malmö \\ University, Malmö, Sweden. \\ Email: annette.holst.hansson@mah.se \\ Funding information \\ Cancer Research Foundation at the \\ Department of Oncology, Malmö University \\ Hospital; Donation Foundation of 1982 for \\ Medical Research and Development
}

This study aimed at exploring how women from Iraq and the former Yugoslavia, diagnosed with breast cancer and living in Sweden, experience their everyday life during radiation therapy. A qualitative research design was used comprising interviews with ten women, five originating from Iraq and five from the former Yugoslavia. Striving to survive, the women experienced their everyday life during radiation therapy as extremely challenging. This experience can be placed into three categories: strategies for survival, keeping up appearances and staying in control. Because of these specific challenges, immigrant women may need additional information and guidance in conjunction with the diagnosis, which may enable them to identify possible sources of support from those closest to them. Also, greater attention should focus on acknowledging the woman behind the diagnosis, regardless of her origin, to develop an individualised support programme to help her cope with everyday life during radiation therapy.

\section{KEYWORDS}

breast cancer, everyday life, immigrant, radiation therapy, women

\section{1 | INTRODUCTION}

The diagnosis of breast cancer and its treatment are known to cause strong emotional reactions in women (Curtis, Groarke, McSharry, \& Kerin, 2014; Lewis et al., 2014; Schubart et al., 2014), and the impact may vary depending on the ethnic origin of the women (Ashing-Giwa \& Lim, 2011). Women from ethnic minorities report lower rates of emotional well-being, higher rates of fear of recurrence (Ashing-Giwa $\&$ Lim, 2011) and more symptoms of depression (Christensen et al., 2009) than non-minority women.

Previous research has demonstrated that ethnicity, lower socioeconomic status and high socioecological stress may lead to poorer health-related quality of life in a multi-ethnic population of women diagnosed with breast cancer in the United States (Ashing-Giwa \& Lim, 2009). When exploring the interaction between health professionals and immigrant women living in Canada, Weerasinghe and Mitchell (2007) found that women experienced insensitivity and unresponsiveness from healthcare professionals, along with an inability to understand the connection they made between their bodies, minds and social health. Patients with cancer from ethnic minorities have also expressed unmet need for informational, emotional, practical and spiritual support from healthcare professionals during their cancer care (Moadel, Morgan, \& Dutcher, 2007).

Immigrant women's attitudes to health, illness and their own health-related behaviour are influenced by perceptions of health in their new country and by the native traditional beliefs from their countries of origin. These cultural factors work in conjunction with other aspects, such as age, education and class (Dellenborg, Skott, \& Jakobsson, 2012; Kleinman \& Benson, 2006). A woman's individual cultural identity and values may influence several aspects of her illness experience, including perception of the illness, relationship with healthcare professionals (and trust in them), willingness and ability to communicate symptoms, preferred type of care and degree of compliance to the recommended care (Bäärnhielm \& Ekblad 
2008; Harmsen, Bernsen, Bruijnzeels, \& Meeuwesen, 2008; Surbone, 2008).

Breast cancer afflicts women worldwide, with 1.7 million women diagnosed in 2012 (World Cancer Research Fund International, 2015); of those, 8,400 were diagnosed in Sweden (The National Board of Health and Welfare, 2013). Like many other European countries, Sweden has been affected by extensive global migration and has become a multicultural society with more than $17 \%$ of its population born in other countries (Statistics Sweden [SCB], 2014).

Global migration is increasing, with 60 million people displaced or living in refugee-like situations (United Nations High Commissioner for Refugees, 2014). Such a situation has not been seen since the Second World War (United Nations High Commissioner for Refugees, 2014), and in 2015, 163,000 people sought asylum in Sweden (Migrationsverket, 2016). In a multicultural society, the frequency of contact with immigrant women with breast cancer will increase, along with the need for more knowledge of their situation and experiences. Migrants from the former Yugoslavia and Iraq are the dominant migrant groups in Sweden after Finns (Statistics Sweden [SCB], 2014). Women born in Iraq, Turkey, Chile, Africa, Iran and Bosnia exhibit lower risk of breast cancer than women born in Sweden and other member countries of the Organisation for Economic Co-operation and Development (OECD; Beiki, Hall, Ekbom, \& Moradi, 2012). However, despite the lower risk of breast cancer for women born in countries such as Iraq and Bosnia, they are at greater risk of dying from it than native Swedish women (Beiki et al., 2012). One reason for this difference may be lack of participation in the screening programme among the elderly and new immigrants (Beiki et al., 2012).

The migration pattern has changed from voluntary labour migrants to refugees fleeing war and persecution (Rostila, 2010), so current immigrants have increased risk of being affected by sociopsychological stress (Al-Baldawi, 2002). A diagnosis of breast cancer can be experienced as an additional stressor that requires even greater adaptation for a woman who is already undergoing an acculturation process due to migration (Berry, 2005). Research has shown that immigrant women living in Sweden have, in general, lower self-rated health status than native Swedish women (Rostila, 2010; The National Board of Health and Welfare, 2007). Despite increasing globalisation, research is still lacking regarding the experience of breast cancer and radiation therapy among immigrant women from Balkan and non-European countries. Consequently, the aim of this study was to explore how women from Iraq and the former Yugoslavia, diagnosed with breast cancer

\begin{tabular}{|c|c|c|c|}
\hline & All included women & Iraqi women & Yugoslavian women \\
\hline & $(n=10)$ & $(n=5)$ & $(n=5)$ \\
\hline \multicolumn{4}{|l|}{ Age (years) } \\
\hline Range (median) & $42-73(50)$ & $44-61(46)$ & $42-73(62)$ \\
\hline \multicolumn{4}{|l|}{ Marital status ( $n$ ) } \\
\hline Married & 4 & 0 & 4 \\
\hline Widow & 2 & 2 & 0 \\
\hline Single & 4 & 3 & 1 \\
\hline \multicolumn{4}{|l|}{ Children (n) } \\
\hline Women giving birth & 10 & 5 & 5 \\
\hline $\begin{array}{l}\text { Women with children } \\
\text { living at home }\end{array}$ & 5 & 3 & 2 \\
\hline \multicolumn{4}{|l|}{ Living in Sweden (years) } \\
\hline Range (median) & $4-49(18)$ & $4-34(18)$ & $12-49(18)$ \\
\hline \multicolumn{4}{|l|}{ Immigration age (years) } \\
\hline Range (median) & $15-54(36)$ & $15-43(25)$ & $21-54(32)$ \\
\hline \multicolumn{4}{|l|}{ Employment } \\
\hline Working & 3 & 1 & 2 \\
\hline Sick leave & 2 & 2 & 0 \\
\hline Retired & 2 & 0 & 2 \\
\hline Unemployed & 3 & 2 & 1 \\
\hline \multicolumn{4}{|l|}{ Surgery } \\
\hline Lumpectomy & 8 & 4 & 4 \\
\hline Mastectomy & 2 & 1 & 1 \\
\hline Chemotherapy & 3 & 3 & - \\
\hline \multicolumn{4}{|l|}{ Radiation therapy } \\
\hline 16 fractions & 3 & 2 & 1 \\
\hline 25 fractions & 7 & 3 & 4 \\
\hline
\end{tabular}

TABLE 1 Characteristics of the participants 
and living in Sweden, experience their everyday life during radiation therapy.

\section{METHODS}

The study has a qualitative research design, comprising interviews aimed at exploring how women from Iraq and the former Yugoslavia experience their everyday life during radiation therapy. A qualitative research approach is appropriate when the aim was to create a deeper understanding of people's individual experiences, perceptions and actions (Patton, 2002).

\section{1 | Sample}

Subjects were recruited at a radiation therapy department at a university hospital in the south of Sweden, where 850 women with breast cancer, $10 \%$ of whom are foreign-born, are treated with radiation therapy annually. The inclusion criteria were women receiving curative radiation therapy for breast cancer, 18 years of age or older, and born in Iraq or the former Yugoslavia. Women who met the inclusion criteria $(n=22)$ were asked to participate in the study, and ten of them accepted, five originating from Iraq and five from the former Yugoslavia. The women who declined participation $(n=12)$ gave the lack of strength to talk about the illness and its treatment as one reason for declining. The participants received radiation therapy for 16 or 25 days, in accordance with national guidelines (SweBCG, 2014), and their demographic and medical variables are listed in Table 1.

\section{2 | Procedure}

The data were collected from March 2013 to April 2014. Registered oncology nurses served as gatekeepers and distributed written and verbal information about the study in the latter part of the participants' treatment period. The written information was translated into Arabic and Bosnian for the women who did not understand Swedish, and interpreters were used when needed. The women were given a week to reflect on their willingness to participate in the study. Those who agreed to participate gave written, informed consent to the gatekeeper, who forwarded it to the first author of this study. The interviews were conducted in conjunction with the women's final treatment session, since the aim was to explore how they experienced everyday life during radiation therapy.

\section{3 | Interviews}

Each interview began with a clarification of the aim of the study and an opportunity for the participants to ask further questions. All the interviews were conducted by the first author $(\mathrm{AHH})$, who was not involved in the care or treatment of the participants. The interviews started with an open question about their experience of radiation therapy. A thematic interview guide was used to enable adjustment of both the form and the sequence of follow-up questions depending on the answers given and the stories told by the participants. A thematic interview guide was chosen because, according to Patton (2002), it enables the interviewer to reach greater depth in the interview, to cover a sequence of themes, and to open up for a freer conversation. The interview guide was developed after reviewing the literature in the field and after a thorough discussion among the authors. The interview guide focused on everyday life, and physical and emotional aspects of everyday life. During the interview, additional and open follow-up questions, such as "How did it feel?", "Could you describe...?", and "What was it like?" were asked, to clarify or further elaborate the participants' answers and to confirm their understanding of the questions. Before the start of the study, one woman from Iraq and one woman from the former Yugoslavia, who were not included in the study, tested the interview guide for comprehensibility. All the interviews were conducted in a secluded room at the hospital and lasted between 20 and $57 \mathrm{~min}$ (median $=30$ ), electronically recorded, and transcribed verbatim. All interviews were conducted in Swedish except for three, which were held with the aid of an interpreter.

\section{4 | Interviews conducted with an interpreter}

Three female, authorised interpreters were used, two Bosnian and one Iraqi commissioned through a national interpretation agency. They were thoroughly informed about the aim of their assignment prior to the interview, as interpreters must be considered a research tool, according to Temple (2002), and must be well informed about the aim of the interview (Kapborg \& Berterö, 2002). During the interviews, the interviewer directly faced the participants, and interpretation was consecutive. Triangular seating was used to help the interviewer remain in control of the interview and make the interpreter less intrusive (Wallin \& Ahlström, 2006).

The electronic files with the interpreted interviews were sent to another national interpretation agency in Sweden for an extra, independent translation. This was to minimise the risk of unspoken metacommunication that might occur in a transcultural interview where the participant and interpreter share the same coherence system (Wallin \& Ahlström, 2006). Metacommunication is often hidden from the interviewer and may cause misunderstanding, misinterpretation and an unreliable result (Ingvarsdotter, Johnsdotter, \& Östman, 2010).

\section{5 | Data analysis}

Qualitative content analysis influenced by the work of Burnard, Gill, Stewart, Treasure, and Chadwick (2008) was applied to the transcribed interview texts. Qualitative content analysis is suitable for exploring, organising and structuring interview texts with the aim of interpreting the underlying meaning of the informants' stories through a number of stages (Burnard, 1996).

In the first stage, the experiences of the participants from Iraq and the former Yugoslavia were analysed separately. The interview transcripts were read through several times to get a sense of the whole. Sentences and phrases were first summarised and then condensed and coded in an open coding. The coded units were sorted and grouped into categories 
that provided an initial coding framework for exploring the participants' experience of everyday life during radiation therapy. In the next step of the analysis, the categories were checked for overlap and further developed and reduced, generating a final coding system with three categories (Table 2). Throughout the analysis process, continual back-and-forth referencing was carried out between the entire text and parts of the text. In the final stage, the categories derived from the Iraqi women and those from the women from the former Yugoslavia were compared and contrasted. The first and fourth author conducted the analysis separately, but, to establish confirmability, the whole team of authors then discussed the identified categories.

\subsection{Ethical considerations}

In accordance with the Declaration of Helsinki (World Medical Association, 2013), the participants were informed that participation was voluntary and could be terminated at any time with no negative consequences. They were also assured that confidentiality would be respected throughout the research process. Informed consent was obtained both verbally and in writing from those willing to participate in the study. The Regional Ethical Review Board in Lund (2012/712) approved this study.

\section{3 | RESULTS}

The women expressed that their breast cancer diagnosis came as a shock and implied that their lives had taken a completely different turn than the one they had foreseen for themselves and their families. They described the moment of receiving the diagnosis as a disaster and comparable to receiving a death sentence, but they also saw it as a challenge they had to overcome. They had to accept their diagnosis and then treading on a narrow treatment road towards survival, with side effects and death lurking on each side of the road. The participants' experiences were classified into three categories: strategies for survival, keeping up appearances and staying in control.

\section{1 | Strategies for survival}

For the women, being diagnosed with breast cancer threw them into an unknown situation, and they were forced to navigate it with the ultimate goal of survival. The diagnosis caused emotional turmoil, leaving the women with feelings of sadness, worry and fear of recurrence. At the same time, they felt hope, joy and gratitude at being alive. They were grateful for the scheduled mammography check-ups, which they

TAB LE 2 Examples of objective findings and analysis

\begin{tabular}{|c|c|c|c|}
\hline Interview transcripts & $\begin{array}{l}\text { Examples of condensed codes (What is it } \\
\text { about/meaning) }\end{array}$ & $\begin{array}{l}\text { Initial coding } \\
\text { framework }\end{array}$ & $\begin{array}{l}\text { Final coding } \\
\text { framework Category }\end{array}$ \\
\hline $\begin{array}{l}\text { "You know, I always have to think of the fact that } \\
\text { I'm sick and that I have to be careful. I don't move } \\
\text { so much, in order not to affect my health } \\
\text { negatively. Oh well." }\end{array}$ & $\begin{array}{l}\text { Afraid that movements and physical activity } \\
\text { will harm health }\end{array}$ & Trying to stay alive & Strategies for survival \\
\hline $\begin{array}{l}\text { "I'm grateful there's such high class treatment and } \\
\text { that they discovered it so early and I think that it's } \\
\text { only in Sweden that mammography works so } \\
\text { well." }\end{array}$ & $\begin{array}{l}\text { Grateful for attending mammography } \\
\text { screening, which led to early detection, and } \\
\text { that cancer treatment in Sweden has a high } \\
\text { standard }\end{array}$ & $\begin{array}{l}\text { Saved by } \\
\text { mammography } \\
\text { and high-class } \\
\text { treatment }\end{array}$ & Strategies for survival \\
\hline $\begin{array}{l}\text { "Living is not easy, but one has to accept whatever } \\
\text { happens since it's determined by fate" }\end{array}$ & Life is not easy but determined by fate & $\begin{array}{l}\text { Accepting one's } \\
\text { fate }\end{array}$ & Strategies for survival \\
\hline $\begin{array}{l}\text { "You have to think positive, otherwise you can't } \\
\text { move on. Nothing gets any better if I lie down and } \\
\text { cry!" }\end{array}$ & $\begin{array}{l}\text { Trying to stay positive in order to move on; } \\
\text { crying does not help }\end{array}$ & $\begin{array}{l}\text { Maintaining a } \\
\text { positive attitude }\end{array}$ & Strategies for survival \\
\hline $\begin{array}{l}\text { "My mom doesn't know I'm sick. I can't tell her } \\
\text { because she lives in X [the home country]" }\end{array}$ & $\begin{array}{l}\text { Avoiding telling her mother about the illness } \\
\text { because she is living in the home country }\end{array}$ & $\begin{array}{l}\text { Protecting family } \\
\text { members }\end{array}$ & $\begin{array}{l}\text { Keeping up } \\
\text { appearances }\end{array}$ \\
\hline $\begin{array}{l}\text { "When I talk to her [the mother], I always tell her } \\
\text { that I'm great, that I'm happy and that I'm healthy" }\end{array}$ & $\begin{array}{l}\text { Pretending to feel great, happy and healthy } \\
\text { when talking to her mother }\end{array}$ & $\begin{array}{l}\text { Protecting family } \\
\text { member }\end{array}$ & $\begin{array}{l}\text { Keeping up } \\
\text { appearances }\end{array}$ \\
\hline $\begin{array}{l}\text { "So I say to my family, we should work together, } \\
\text { and it will be alright, life will become better" }\end{array}$ & $\begin{array}{l}\text { Reassuring the family that by working } \\
\text { together they are going to make it and life } \\
\text { will be better }\end{array}$ & Staying strong & $\begin{array}{l}\text { Keeping up } \\
\text { appearances }\end{array}$ \\
\hline $\begin{array}{l}\text { "They [the nurses] are so nice and kind every day } \\
\text { and I get to talk to them and can ask about } \\
\text { anything" }\end{array}$ & $\begin{array}{l}\text { Encouraged to talk and ask questions by } \\
\text { kind and empathic nurses }\end{array}$ & $\begin{array}{l}\text { Support from the } \\
\text { nurses }\end{array}$ & Staying in control \\
\hline $\begin{array}{l}\text { Many worrying thoughts arise, especially at night } \\
\text { when I'm alone and can't sleep. "Then I wonder if } \\
\text { I'm going to beat this disease, if I'm going to } \\
\text { survive, and then the only thing to do is to call my } \\
\text { sisters and talk to them. That makes me calmer" }\end{array}$ & $\begin{array}{l}\text { Talking to one's sisters decreases the } \\
\text { distress and fear of not surviving that arises } \\
\text { during the night when alone and sleepless }\end{array}$ & $\begin{array}{l}\text { Support from the } \\
\text { family }\end{array}$ & Staying in control \\
\hline "I get strength from my faith, and that helps me" & Feels that religion and faith give strength & $\begin{array}{l}\text { Strength provided } \\
\text { by faith }\end{array}$ & Staying in control \\
\hline
\end{tabular}


felt had increased their chances of survival. However, they were also overwhelmed by thoughts of death and their greatest fear, namely not being able to continue to care for their children: "You know that every woman is afraid, not of dying, but of having to leave their children; you always want to be able to take care of your children."

The Iraqi women accepted the illness as God's will but felt they had to do whatever they could to survive. They did not perform any physical activity due to their fear of jeopardising their health and reducing their chances of survival. They also saw both their faith in God and their co-operation with healthcare professionals as ways of improving their odds of survival. The women expressed feelings of fear and guilt about feeling low and depressed because they associated these feelings with lower rates of survival. For some of the Iraqi women, their distress and feelings of sadness became a downward spiral that they felt undermined their efforts to survive. This forced them to attempt to adopt a positive attitude and constantly push their negative feelings aside to boost hopes of survival.

For the Yugoslavian women, the unexpected diagnosis led to an everyday struggle to try to understand what had caused their illness. They were shocked by the diagnosis since they knew that they had breastfed their children, lived healthy lifestyles and had no known family history of breast cancer. When seeking explanations for their illness, they expressed feelings of fatalism: "There's always a greater meaning to everything that happens in life. There's a reason for everything." They felt their illness was determined by fate, but were determined not to give up without a fight. Thus, all participants, Yugoslavian and Iraqi, tried to stay positive about their journey that was experienced as a narrow road to survival.

\section{2 | Keeping up appearances}

After diagnosis, the women's need to spare their family emerged, a need that persisted throughout the radiation therapy period. Despite wanting support from their mothers, siblings, children and other relatives, when meeting relatives and acquaintances, they tried hard to be strong and conceal their fear of not surviving. They kept their illness to themselves or only confided in one or two people who were close to them: "I always show myself as strong in front of others, both for my family and at work, but l'm not strong. I don't want to show my feelings."

The Iraqi women tried to delay informing their families about their illness and treatment. Sometimes, the healthcare professionals had to persuade them to let their children know: "I didn't tell my son anything until after the surgery... or after I started my radiation therapy." Although reluctant to inform their children, they experienced a sense of relief when they had performed so. The Iraqi women tried to keep up appearances and conceal their illness when talking on the phone to relatives living in their home country. This led to feelings of distress that increased when they were alone, especially those living without a partner. It resulted in feelings of living in a divided world; one part was the women's authentic, but troubled inner world, and the other was false, but seemingly happy and healthy outer world: "When I talk to my mom on the phone, I make a joke and she laughs, but inside, I'm crying."
The Yugoslavian women also concealed their illness and treatment. For example, they always showed a positive facade to their employers and colleagues, as they did not want the illness, or the treatment, to affect their work. Instead, they demonstrated pride in their ability to endure work and manage their entire treatment without one single day of sick leave: "Sometimes I work weekends so I don't miss my hours. I haven't been on sick leave a minute; today I took paid vacation." Both Yugoslavian and Iraqi women experienced their everyday life as a struggle not to let their facade of normality and health hinders their journey towards survival.

\subsection{Staying in control}

The side effects of radiation therapy forced the women to develop strategies for maintaining control and remaining on track towards survival. One strategy was to stay in close contact with the nurses in the treatment team, which increased their self-efficacy and helped them feel safe and supported. They appreciated clear, honest and accurate information, as it instilled trust in the nurses. The women felt they did not have to pretend to be strong in front of the nurses: "I don't understand how they [the staff] manage, how they don't get tired of us I talk to them and can ask about everything. It's important that they listen to me, what I feel, and how I feel, and that they help me and that they are calm, you feel that."

Another strategy to maintain control was to turn to God, and the Iraqi women described faith as a way to manage their everyday lives. Religion gave meaning to the illness and was experienced as a companion during times of isolation, offering a source of strength and hope: "When I feel sad, I pray or read the Quran. It gives me support, and sometimes I feel that what I read in the Quran is about me, and that makes me stronger." They also felt that prayers made the nights more manageable when hot flushes due to anti-hormonal treatment disturbed their sleep, and feelings of sadness and loneliness would hit them. While finding emotional support and a helping hand in God, they also experienced the illness as a test from God.

While the Iraqi women found God to be a source of control, the Yugoslavian women found their family, relatives and friends to be their source of support. Members of the women's support circle drove them to their treatment, brought them food, helped them with chores and kept them company whenever they felt in need of it. "I didn't allow my friends and relatives to help me as much as they would have liked to because I want to live my life as normally as possible in order to feel physically and psychologically well." Although the support was highly appreciated, the women expressed a need to stay on top of their situation and maintain control of their everyday lives during their journey towards survival.

\section{4 | DISCUSSION}

The experiences of everyday life during radiation therapy, from the perspectives of Iraqi and Yugoslavian women, show both similarities with other cultural or ethnic groups and some unique features. Some 
results are of special interest. One finding is the explicit struggle of the women in this study to stay strong and survive for the sake of their children, something that may be universal and is consistent with findings from other research by Holst-Hansson, Sjövall, Idvall, and Bolmsjö (2013) and Kwok and White (2011).

The Iraqi women attempted to conceal their diagnosis and remain strong, to the extent that they were left on their own instead of accepting the family as a possible source of support in their daily lives. This could be explained by the fact that they were younger than the women from the former Yugoslavia. Research has shown that younger women often demonstrate poorer psychosocial adjustment during and following breast cancer treatment (Ahmad, Fergus, \& McCarthy, 2015; Schubart et al., 2014) and express an unmet need of professional and emotional support when communicating their cancer diagnosis to their children (Asbury, Lalayiannis, \& Walshe, 2014; Semple \& McCance, 2010). However, this may also reflect the perception of the woman as the pillar of the home, strong and available for family members to the detriment of her own needs and difficulties, as shown by Goldblatt, Cohenz, Azaiza, and Manassa (2013) when exploring how Arabic women living in Israel experience and cope with breast cancer.

Outwardly, all the women in our study presented a positive and healthy image to the people around them but felt as if they were falling apart inwardly. This duality was an extra burden, as everyday life became an act that had to be performed no matter what-a facade that was always maintained, since they did not even allow the side effects from radiation therapy stop them from working.

The women's reluctance to tell their families about their breast cancer has also been reported in other qualitative research (Curtis et al., 2014; Remmers, Holtgrave, \& Pinkert, 2010), so it is important for healthcare professionals to encourage women to talk about their illness and treatment. These findings also argue in favour of specific interventions to assist women in preparing to narrate their story, in the form of an individualised support programme. For instance, the woman and her family could be invited to attend joint information meetings about the diagnosis, the treatment and its side effects. At the same time, healthcare professionals must consider the importance of treating the woman with respect and allowing her to speak freely about her beliefs, values and preferences-especially regarding bringing her family to the hospital-to avoid violating her trust and diminishing her as a person (Ekman et al., 2011).

The close contact with the nurses in the treatment team was paramount and emphasised by all the women as an essential source of support; sometimes, the nurses provided their only daily support. The nurses have a unique possibility to interact with these women, given that they meet daily for 3-6 weeks. Healthcare professionals could routinely ask patients about their everyday lives, as they may be the only people an immigrant woman has daily contact with or can confide in. This study shows that there is reason to believe that some women may lack support outside the hospital sphere, irrespective of how long they have lived in Sweden.

The religious coping mechanism used by the Iraqi women and the fatalistic thoughts and concerns expressed by the Yugoslavian women show that healthcare professionals should be attentive to immigrant women's views about religious matters. Using religious practices and spirituality for coping with breast cancer and its treatment is also evident in other research (Al-Azri, Al-Awizi, Al-Rasbi, \& Al-Moundhri, 2014; Finney et al., 2015; Lackey, Gates, \& Brown, 2001; Lagman, Yoo, Levine, Donnell, \& Lim, 2014; Obeidat, Lally, \& Dickerson, 2012). An inclusive and open approach by healthcare professionals would allow women to feel that their faith is also an essential part of managing their diagnosis and treatment. The healthcare professionals' awareness of and respect for religious and spiritual needs and beliefs may improve the emotional and psychosocial situation, as well as reducing psychological concerns (Al-Azri et al., 2014).

Evidence is emerging that physical activity before and after a cancer diagnosis is beneficial, in terms of both reduced mortality and patient-reported side effects, such as fatigue, depression and reduced quality of life (Ariza-Garcia et al., 2013; Bouillet et al., 2015). Iraqi women's belief that physical activity may be unfavourable for their health and chances of survival is thus a worrying finding. The unjustified fear of physical activity is another example that reinforces the importance of healthcare professionals encouraging women to narrate their thoughts and knowledge of causalities for health and illness, to be able to support them in their fight for survival.

There is a gradual, ongoing process in the biomedical and traditional approach in healthcare where the patient is being upgraded to a participating expert in the care, supplementing the professionals regarding diagnosis and treatment. Allowing these women to narrate their personal thoughts on how the diagnosis affects their everyday lives give healthcare professionals the opportunity to provide more personal support. This may be especially significant with regard to immigrants, as Butow et al. (2011) have reported that immigrants diagnosed with cancer experience difficulty in communicating with their cancer team, which can lead to feelings of loneliness and misunderstanding. The result from this study, in addition to research on native women with breast cancer by Halkett and Kristjanson (2007) and Holst-Hansson et al. (2013), shows that relationships can develop between women with breast cancer and the nurses in their treatment team, offering the women a sense of emotional comfort and security.

\section{STRENGTHS AND LIMITATIONS}

The trustworthiness, explicit credibility, transferability, dependability and confirmability of the study were continually assessed through the research process (Lincoln \& Guba, 1985). Two of the authors analysed the data independently, thereby improving credibility. The extra, independent translation of the recorded interviews conducted with an interpreter showed no signs of unspoken metacommunication or misinterpretation, which also strengthens the credibility of the study. The first author conducted all the interviews in the same manner and posed similar follow-up questions to all the respondents, strengthening dependability. Efforts were also made during the interviews to achieve a mutual understanding of the meaning of the questions and responses, as well as inviting the respondents to develop their 
narratives; this approach was even more emphasised when an interpreter was present.

Confirmability was enhanced by providing clear descriptions of each stage of the research process and by presenting quotations from the interview transcripts throughout the categorisation of results. The quotations were translated and back-translated by a qualified and registered translator outside the research team to ensure accuracy.

Qualitative research does not attempt to generalise information (Lincoln \& Guba, 1985) but rather to elucidate the detailed and specific. Patton (2002) states that there are no specific rules regarding sample size in qualitative research, but that it should be large enough to obtain feedback for most or all perceptions. There are few guidelines for estimating suitable sample size (Marshall, Cardon, Poddar, \& Fontenot, 2013), but one approach is to apply recommendations by qualitative methodologists (Tan, Cater-Steel, \& Toleman, 2009). For example, Creswell (2013) recommends 20-30 participants in grounded theory studies, to achieve a theory that is well saturated. For phenomenological studies, sample sizes ranging from 3 to 10 (Dukes, 1984) and 6 to 10 (Morse, 2000) are recommended. Equivalent recommendations for content analysis are lacking, so we cannot claim that the sample size in our study $(n=10)$ is completely in line with recommendations from leading qualitative research methodologists.

Another possibility is to follow sample sizes used in studies exploring similar research problems (Mason, 2010). Previous qualitative studies exploring the experiences of women with breast cancer and belonging to an ethnic minority involved ten (Lagman et al., 2014; Obeidat et al., 2012) and 13 (Lackey et al., 2001) participants. Consequently, our sample size corresponds well with those used in previous research about experiences of women with breast cancer and belonging to an ethnic minority. It is also the first step towards exploring the experiences of everyday life during radiation therapy from the perspectives of women with breast cancer originating from Iraq and the former Yugoslavia.

Many of the invited patients declined participation. Knobf (2007) showed difficulties in recruiting minorities for nursing or any other research. However, a strength of this study is that it includes women who are unable to speak the language spoken in the host country, while most studies exclude this group.

To the best of our knowledge, this is the first study to focus on everyday life experiences during radiation therapy from the perspective of female, immigrant, patients with breast cancer originating from Iraq and the former Yugoslavia. This gap in knowledge may be due to the relatively young age of this immigrant population, who arrived in Sweden and other western European countries mainly in the 1990s and thereafter (Hemminki, Ji, Brandt, Mohsen Mousavi, \& Sundquist, 2010).

\section{6 | CONCLUSION}

It is important for healthcare professionals to identify immigrant women with breast cancer experiencing an unmet need of support. This particularly applies to women who manage their treatment and its side effects without support from family or relatives; they may need extra information and support in identifying possible sources of support from those closest to them. Healthcare professionals must be more attentive to the women's psychosocial response to breast cancer from the time of diagnosis and throughout treatment trajectory, to deal with expedient cross-cultural clinical measures of emotiona outcomes. In conclusion, more attention should focus on acknowledging the woman behind the diagnosis, regardless of origin, to develop individualised support programmes aiming at further facilitate her everyday life during radiation therapy.

\section{ACKNOWLEDGEMENTS}

We would like to thank the women who participated in the interviews. We are also grateful to the Cancer Research Foundation at the Department of Oncology, Malmö University Hospital and the Donation Foundation of 1982 for Medical Research and Development for making this study feasible through financial support

\section{CONFLICT OF INTEREST}

All authors of this study certify that there is no conflict of interests to declare.

\section{ORCID}

A. Holst-Hansson (D) http://orcid.org/0000-0001-7410-0811

\section{REFERENCES}

Ahmad, S., Fergus, K., \& McCarthy, M. (2015). Psychosocial issues experienced by young women with breast cancer: The minority group with the majority of need. Current Opinion in Supportive \& Palliative, 9 271-278.

Al-Azri, M. H., Al-Awizi, H., Al-Rasbi, S., \& Al-Moundhri, M. (2014). Coping with a diagnosis of breast cancer among Omani women. Journal of Health Psychology, 19(7), 836-846.

Al-Baldawi, R. (2002). Migration-related stress and psychosomatic consequences. International Congress Series, 1241, 271-278.

Ariza-Garcia, A., Galiano-Castillo, N., Cantanero-Villanueva, I., FernandezLao, C., Diaz-Rodriguez, L., \& Arroyo-Morales, M. (2013). Influence of physical inactivity in psychophysiological state of breast cancer survivors. European Journal of Cancer Care, 22, 738-745.

Asbury, N., Lalayiannis, L., \& Walshe, A. (2014). How do I tell the children? Women's experiences of sharing information about breast cancer diagnosis and treatment. European Journal of Oncology Nursing, 18, 564-570.

Ashing-Giwa, K. T., \& Lim, J. W. (2009). Examining the impact of socioeconomic status and socioecologic stress on physical and mental health quality of life among breast cancer survivors. Oncology Nursing Forum, 36(3), 79-85.

Ashing-Giwa, K. T., \& Lim, J. W. (2011). Examining emotional outcomes among a multiethnic cohort of breast cancer survivors. Oncology Nursing Forum, 38(3), 279-288.

Bäärnhielm, S., \& Ekblad, S. (2008). Introducing a psychological agenda for understanding somatic symptoms-An area of conflict for clinicians in relation to patients in a multicultural community. Culture, Medicine, and Psychiatry, 32, 386-405. 
Beiki, O., Hall, P., Ekbom, A., \& Moradi, T. (2012). Breast cancer incidence and case fatality among 4.7 million women in relation to social and ethnic background: A population-based cohort study. Breast Cancer Research, 14, R5.

Berry, J. W. (2005). Acculturation: Living successfully in two cultures. International Journal of Intercultural Relations, 29, 697-712.

Bouillet, T., Bigard, X., Brami, C., Chouahnia, K., Copel, L., Dauchy, S., ... Zelek, L. (2015). Role of physical activity and sport in oncology. Scientific Commission of the National Federation Sport and Cancer CAMI. Critical Reviews in Oncology and Hematology, 94(1), 74-86.

Burnard, P. (1996). Teaching the analysis of textual data: An experiential approach. Nurse Education Today, 16(4), 278-281.

Burnard, P., Gill, P., Stewart, K., Treasure, E., \& Chadwick, B. (2008). Analysing and presenting qualitative data. British Dental Journal, 8, 429-432.

Butow, P. N., Sze, M., Dugal-Beri, P., Mikhail, M., Eisenbruch, M., Jefford, M., ... Psycho-Oncology Co-operative Research Group (PoCoG) (2011). From inside the bubble: Migrants' perceptions of communication with the cancer team. Supportive Care in Cancer, 19, 281-290.

Christensen, S., Zachariae, R., Bonde Jensen, A., Væth, M., Møller, S., Ravnsbæk, J., ... von der Maase, H. (2009). Prevalence and risk of depressive symptoms 3-4 months post-surgery in a nationwide cohort study of Danish women treated for early stage breast-cancer. Breast Cancer Research and Treatment, 113, 339-355.

Creswell, J. W. (2013). Qualitative inquiry and research design: Choosing among five traditions. Thousand Oaks, CA: Sage Publications.

Curtis, R., Groarke, A. M., McSharry, J., \& Kerin, M. (2014). Experience of breast cancer. Burden, benefit, or both? Cancer Nursing, 37(3), E21-E30.

Dellenborg, D., Skott, C., \& Jakobsson, E. (2012). Transcultural encounters in a medical ward in Sweden: Experiences of health care practitioners. Journal of Transcultural Nursing, 23(4), 342-350.

Dukes, S. (1984). Phenomenological methodology in the human sciences. Journal of Religion and Health, 23(3), 197-203.

Ekman, I., Swedberg, K., Taft, C., Lindseth, A., Norberg, A., Brink, E., ... Lidén, E. (2011). Person-centered care-ready for prime time. European Journal of Cardiovascular Nursing, 10(4), 248-251.

Finney, J. M., Hamilton, J. B., Hodges, E. A., Pierre-Louis, B. J., Crandell, J. L., \& Muss, H. B. (2015). African American cancer survivors: Do cultural factors influence symptom distress? Journal of Transcultural Nursing, 26(3), 294-300.

Goldblatt, H., Cohenz, M., Azaiza, F., \& Manassa, R. (2013). Being within or being between? The cultural context of Arab women's experience of coping with breast cancer in Israel. Psycho-Oncology, 22, 869-875.

Halkett, G. K. B., \& Kristjanson, L. (2007). Patients' perspectives on the role of radiation therapists. Patient Education and Counseling, 69, 76-83.

Harmsen, H., Bernsen, R., Bruijnzeels, M., \& Meeuwesen, L. (2008). Patients' evaluation of quality of care in general practice: What are the cultural and linguistic barriers? Patient Education and Counseling, 72, 155-162.

Hemminki, K., Ji, J., Brandt, A., Mohsen Mousavi, S., \& Sundquist, J. (2010). The Swedish Family-Cancer Database 2009: Prospects for histologyspecific and immigrant studies. International Journal of Cancer, 126, 2259-2267.

Holst-Hansson, A., Sjövall, K., Idvall, E., \& Bolmsjö, I. (2013). The breath of life: Womens' experiences of breathing adapted radiation therapy. European Journal of Oncology Nursing, 17, 354-359.

Ingvarsdotter, K., Johnsdotter, S., \& Östman, M. (2010). Lost in interpretation: The use of interpreters in the research on mental health illness. International Journal of Social Psychiatry, 58(1), 34-40.

Kapborg, I., \& Berterö, C. (2002). Using an interpreter in qualitative interviews: Does it threaten validity? Nursing Inquiry, 9(1), 52-56.

Kleinman, A., \& Benson, P. (2006). Anthropology in the clinic: The problem of cultural competency and how to fix it. PLoS Medicine, 3(10), e294.

Knobf, M. T. (2007). Challenges and strategies in recruitment of ethnically diverse populations for cancer nursing research. Oncology Nursing Forum, 34(6), 1187-1194.
Kwok, C., \& White, K. (2011). Cultural and linguistic isolation: The breast cancer experience of Chinese-Australian women - A qualitative study. Contemporary Nursing, 39(1), 85-94.

Lackey, N. R., Gates, M. F., \& Brown, G. (2001). African American women's experiences with the initial discovery, diagnosis, and treatment of breast cancer. Oncology Nursing Forum, 28(3), 519-527.

Lagman, R. A., Yoo, G. J., Levine, E. G., Donnell, K. A., \& Lim, H. R. (2014). "Leaving it to God" religion and spirituality among filipina immigrant breast cancer survivors. Journal of Religious Health, 53, 449-460.

Lewis, F., Merckaert, I., Liénard, A., Libert, Y., Etienne, A. M., Reynaert, C., ... Razavi, D. (2014). Anxiety and its time courses during radiotherapy for non-metastatic breast cancer: A longitudinal study. Radiotherapy and Oncology, 111, 276-280.

Lincoln, Y. S., \& Guba, E. G. (1985). Naturalistic inquiry. Beverly Hills, CA: Sage Publications.

Marshall, B., Cardon, P., Poddar, A., \& Fontenot, R. (2013). Does sample size matter in qualitative research?: A review of qualitative interviews in IS research. Journal of Computer Information System, 54(1), 11-22.

Mason, M. (2010). Sample size and saturation in PhD studies using qualitative interviews [63 paragraphs]. Forum: Qualitative Social Research, 11(3), Art. 8. Retrieved from http://nbn-resolving.de/ urn:nbn:de:0114-fqs100387

Migrationsverket (2016). Current statistics. Retrieved from http://www. migrationsverket.se/Om-Migrationsverket/Statistik/Aktuell-statistik. html

Moadel, A. B., Morgan, C., \& Dutcher, J. (2007). Psychosocial needs assessment among underserved, ethnically diverse cancer patient population. Cancer, 109(2 Suppl.), 446-454.

Morse, J. M. (2000). Determining sample size. Qualitative Health Research, 10(1), 3-5.

Obeidat, R. F., Lally, R. M., \& Dickerson, S. S. (2012). Arab American women's lived experience with early-stage breast cancer diagnosis and surgical treatment. Cancer Nursing, 35(4), 303-311.

Patton, M. Q. (2002). Qualitative research \& evaluation methods. London: Sage.

Remmers, H., Holtgrave, M., \& Pinkert, C. (2010). Stress and nursing care needs of women with breast cancer during primary treatment: A qualitative study. European Journal of Oncology Nursing, 14(11), 11-16.

Rostila, M. (2010). Birds of a feather flock together - and fall ill? Migrant homophily and health in Sweden. Sociology of Health \& IIIness, 32(3), 382-399.

Schubart, J. R., Emerich, M., Farnan, M., Stanley Smith, J., Kauffman, G. L., \& Kass, R. B. (2014). Screening for psychological distress in surgical breast cancer patients. Annals of Surgical Oncology, 21, 3348-3353.

Semple, C. J., \& McCance, T. (2010). Experience of parents with head and neck cancer who are caring for young children. Journal of Advanced Nursing, 66, 1280-1290.

Statistics Sweden [SCB] (2014). Population statistics. Foreign-born citizens. Retrieved from http://www.statistikdatabasen.scb.se/pxweb/ sv/ssd/START__BE__BE0101__BE0101E/UtrikesFoddaR/table/ tableViewLayout1/?rxid=3fc24e9e-3379-4960-b393-4d83065f1cf2

Surbone, A. (2008). Cultural aspects of communication in cancer care. Supportive Care in Cancer, 16, 235-240.

SweBCG, Sweden Breast Cancer Group (2014). National Care Program for Breast Cancer, Retrieved from http://www.swebcg.se/wp-content/uploads/2016/09/NVP-Bröstcancer-2014.pdf

Tan, W., Cater-Steel, A., \& Toleman, M. (2009). Implementing IT service management: A case study focusing on critical success factors. Journal of Computer Information Systems, 50(2), 1-12.

Temple, B. (2002). Crossed wires: Interpreters, translators, and bilingual workers in cross-language research. Qualitative Health Research, 12(6), 844-854.

The National Board of Health and Welfare (2007). Self-reported health of people of foreign origin - A basis for concerted reporting of integration policy outcomes. Stockholm. 
The National Board of Health and Welfare (2013). Cancer statistics. Retrieved from http://www.socialstyrelsen.se/Lists/Artikelkatalog/ Attachments/19108/2013-6-5.pdf

United Nations High Commissioner for Refugees, UNHCR (2014). The UN Refugee Agency. Retrieved from http://unhcr.org/cgi-bin/texis/vtx/ home

Wallin, A. M., \& Ahlström, G. (2006). Cross-cultural interview studies using interpreters: Systematic literature review. Journal of Advanced Nursing, 55(6), 723-735.

Weerasinghe, S., \& Mitchell, T. (2007). Connection between the meaning of health and interaction with health professionals: Caring for immigrant women. Health Care for Women International, 28, 309-328.

World Cancer Research Fund International (2015). Breast cancer statistics. Retrieved from http://www.wcrf.org/int/cancer-facts-figures/ data-specific-cancers/breast-cancer-statistics
World Medical Association (WMA) (2013). WMA - Declaration of HelsinkiEthical principles for medical research involving human subjects. Retrieved from http://www.wma.net/en/30publications/10policies/ b3/index.html

How to cite this article: Holst-Hansson A, Idvall E, Bolmsjö I, Wennick $A$. The narrow treatment road to survival: Everyday life perspectives of women with breast cancer from Iraq and the former Yugoslavia undergoing radiation therapy in

Sweden. Eur J Cancer Care. 2018;e12825.

https://doi.org/10.1111/ecc.12825 



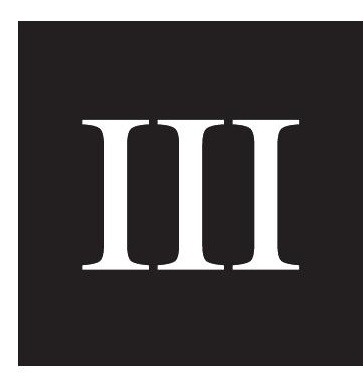





\title{
Hoping to reach a safe haven - Swedish families' lived experience when a family member is diagnosed with breast cancer
}

\author{
Annette Holst-Hansson ${ }^{\mathrm{a}, \mathrm{b}, *}$, Ewa Idvall ${ }^{\mathrm{a}}$, Ingrid Bolmsjö ${ }^{\mathrm{a}}$, Anne Wennick ${ }^{\mathrm{a}}$ \\ a Malmö University, Faculty of Health and Society, Department of Care Science, Malmö, Sweden \\ b Skåne University Hospital, Department of Hematology, Oncology and Radiation Physics, Lund, Sweden
}

\begin{abstract}
A B S T R A C T
Purpose: When a woman is diagnosed with breast cancer, it affects all family members. Therefore, the aim of this study was to elucidate family members lived experience when a family member is diagnosed with breast cancer. Method: The study had a hermeneutic phenomenological design including individual conversational interviews conducted face-to-face with six women with breast cancer and their family members at two different points of time, in order to elucidate families' lived experience, both as individuals and as a unit, from each family member's perspective.

Results: Living as a family in the presence of breast cancer is a challenging endeavour to regain an ordinary, safe life, hoping to reach a safe haven. The families felt that life as they knew it had disappeared and they were fumbling in the dark, trying to find support and guidance on their path to ordinary life. The family members were pursuing balance by attempting to keep the family together and maintaining a positive attitude while battling against fear and treatment-related side effects. Finally, the families were struggling with guilt and inadequacy, due to their difficulties in communicating the emotional distress that the illness brought upon them, at the same time as they felt abandoned by the healthcare professionals.

Conclusions: Families experience an unmet need of information and support, which implies that healthcare professionals may want to acknowledge and include the family already at the time of diagnosis in order to help them endure and cope with the distressing experience and thus increase their wellbeing.
\end{abstract}

\section{Introduction}

Women diagnosed with breast cancer describe their experience in terms of shock, fear, anger, distress, and anxiety (Fu et al., 2009; Schubart et al., 2014), and research shows that breast cancer and its subsequent treatment also have an impact on family members (Coyne et al., 2012). There is a growing interest in how the family experiences the woman's breast cancer diagnosis, although few studies elucidating family experience have included both the patient and her family (Robbins et al., 2013). Instead, previous research has explored family experience focusing on the spouse's experience (Lewis et al., 2008; Lopez et al., 2012), the child's experience (Edwards et al., 2008), or a couple's dyadic experience (Belcher et al., 2011; Sprung et al., 2011). Knowledge of individual experience is important, but insights from several family members may offer a wider overview of family experience when a family member is diagnosed with breast cancer.

\section{Literature review}

Breast cancer is the most common female malignancy worldwide (Siegel et al., 2013). Research has shown that women diagnosed with and treated for breast cancer experience distress, fear of recurrence, and worry about their children (Lebel et al., 2013; Stinesen Kollberg et al., 2013), and that young women in particular emphasise their unmet supportive needs, and their lack of information and counselling (Adams et al., 2011; Schmid-Büchi et al., 2013). Women have also expressed a need for professional and emotional support when communicating their cancer diagnosis to their children (Asbury et al., 2014; Semple and McCance, 2010), which implies that the woman should be seen in the context of her family.

Family responses to breast cancer have been explored by recruiting the patient and one family member, often the spouse, to provide information, and these studies have highlighted the fact that spouses and other close relatives may experience increased levels of anxiety and depression (Fletcher et al., 2010; Lewis et al., 2008; Schmid-Büchi et al., 2011), as well as reduced quality of life (Duggleby et al., 2013;

\footnotetext{
Corresponding author. Faculty of Health and Society, Department of Care Science, SE 205 06, Malmö, Sweden.

E-mail address: annette.holst.hansson@mah.se (A. Holst-Hansson).
}

http://dx.doi.org/10.1016/j.ejon.2017.10.003

Received 12 May 2017; Received in revised form 8 October 2017; Accepted 9 October 2017 1462-3889/(C) 2017 Elsevier Ltd. All rights reserved. 
Wagner et al., 2006). The spouses also express a perceived lack of support and information from healthcare professionals (Northouse et al., 2005).

Other researchers have elucidated children's experiences of parental cancer, finding these children affected by distress, emotional and behavioural problems, as well as unmet informational and supportive needs (Huang et al., 2014; Vannatta et al., 2008), but also equipped with strength to adapt to and normalise their situation (Clemmens, 2009). Further, researchers have found that an enhanced adjustment to parental cancer may be associated with better family function (Krattenmacher et al., 2012; Vannatta et al., 2010).

The emotional impact that an illness like breast cancer has on the individual family members reveals that a cancer diagnosis is always a family affair (Wright and Leahey, 1994). A family can be described as a system in which the family members interact mutually; they represent elements in relationship to each other and, when in balance, this system assures the members of predictability, security, and feelings of connectedness. A severe illness like breast cancer in a family member may lead to an imbalance and a loss of security for all members of the family system (Wright and Leahey, 2013). The strain that a breast cancer diagnosis can put on the family is something that needs attention from healthcare professionals. In the USA, for example, almost 20 per cent of adult cancer patients are parenting dependent children, parental cancer thereby affecting three million children in that country alone (Weaver et al., 2010). Having a family member with cancer may lead to mental and physical illness in partners and close relatives (Sjövall, 2011; Stenberg et al., 2010), as well as considerable levels of anxiety and supportive needs years after successful treatment (Hodgkinson et al., 2007). Nissen et al. (2016) also found that lower levels of perceived social support and quality of life in caregivers of advanced cancer patients could be associated with worse family function. However, partners and relatives are not only co-sufferers; they may also be the emotional support the affected woman needs in order to manage treatment and daily life (Arora et al., 2007; Coyne et al., 2012), which reinforces the need to include multiple family members in care and research. There seems to be a paucity of research focusing on both the affected woman and the members of her family, as well as on elucidating the family's lived experience, as individuals and as a unit, in the presence of breast cancer.

\section{Aim}

The aim of this study was to elucidate family member's lived experience when a family member is diagnosed with breast cancer.

\section{Method}

\subsection{Design}

The study design was descriptive and inductive, including individual, conversational interviews conducted face-to-face with six women diagnosed with breast cancer and their family members. The methodological approach chosen was hermeneutic phenomenology influenced by van Manen (2001). The interviews were conducted at two different time points to generate deeper meaning and allow participants to reflect on their lived experience in accordance with the recommendation of van Manen (2001).

\subsection{Sample and setting}

The recruitment was done at a radiation therapy department at a university hospital in the south of Sweden, where 850 women yearly are treated with radiation therapy (henceforth referred to as RT). The inclusion criteria were Swedish-speaking women with breast cancer and their family members (husbands, sons, and daughters) aged 12 and older. The lower age limit was set at 12 years, since children begin to develop their abstract thinking by the age of 12 , which means that they can have their own opinions and perceive multidimensional situations (Belmont, 1989; Piaget, 1972). Since a variety in sample size ranging between 3 and 10 (Dukes, 1984), 6 (Guest et al., 2006), and 6-10 (Morse, 2000) is recommended for phenomenological studies, we projected to include 5-7 families. Thus, a total of six women who met the study's eligibility criteria were consecutively approached during their first visit at the RT department and invited to participate in this hermeneutical phenomenological study. The women signed a consent form for the release of their contact information and received written information addressed to themselves and their adult family members, as well as age-specific written information for their children. In this study, Wright and Leahey's (2013) definition of a family was used: "the family is who they say they are" (p. 33). Hence, a family is constituted by those who feel that they belong to the family, regardless of how their relations are viewed from the outside. Eligible participants were therefore asked to identify close family members who shared the illness experience and whom they specifically defined as belonging to their family. A family is a system consisting of individuals interacting with and affecting each other (Wright and Leahey, 2013). Thus, to capture the whole family's lived experience, each family member was seen as equally important. After being given two days to reflect and discuss their participation with their family members, each woman was contacted by the interviewer (AHH), by telephone. All of the women asked consented to participate and the time and location for the interviews, chosen by the families, was scheduled. Six families consisting of a total of 19 family members, including the six women with breast cancer, were included; however, a father and a sibling, in two different families, declined to participate. Two siblings were younger than 12 years and were therefore excluded. All of the participating women had undergone surgery, chemotherapy, and RT for 25 days, except one woman who had received RT for 15 days. The time span from diagnosis to the second interview ranged from 7.5 to 8.5 months $(\mathrm{md}=8.2$ ). The characteristics of the participating families are presented in Table 1.

\subsection{Data collection}

Individual, conversational interviews were conducted face-to-face

Table 1

Family characteristics $(\mathrm{n}=6)$

\begin{tabular}{llllll}
\hline $\begin{array}{l}\text { Family } \\
\text { members }\end{array}$ & $\begin{array}{l}\text { Woman with } \\
\text { breast cancer }\end{array}$ & $\begin{array}{l}\text { Family member (age, gender and } \\
\text { relation to woman with breast } \\
\text { cancer) }\end{array}$ & $\begin{array}{l}\text { Family member (age, gender and } \\
\text { relation to woman with breast } \\
\text { cancer) }\end{array}$ & $\begin{array}{l}\text { Family member (age, gender and } \\
\text { relation to woman with breast } \\
\text { cancer) }\end{array}$ & $\begin{array}{l}\text { Family member (age, gender and } \\
\text { relation to woman with breast } \\
\text { cancer) }\end{array}$ \\
\hline Family 1 & Woman, 50 years & Son, 12 years & - & - & - \\
Family 2 & Woman, 41 years & Husband, 39 years & Son, 14 years & - & - \\
Family 3 & Woman, 55 years & Daughter, 12 years & - & - & - \\
Family 4 & Woman, 45 years & Husband, 48 years & Daughter, 14 years & Daughter, 18 years & Daughter, 20 years \\
Family 5 & Woman, 51 years & Son 14 years & Daughter, 16 years & - & - \\
Family 6 & Woman, 47 years & Husband, 58 years & Daughter, 14 years & Daughter, 18 years & - \\
\hline
\end{tabular}


on two different occasions with each of the 19 family members, including the six women with breast cancer ( $\mathrm{n}=6$ families), to obtain an in-depth understanding of the unique experience of each family member. The interviews lasted as long as was needed for each participant to narrate their story and until no follow-up questions triggered a continuation but a calm silence occurred. The first interview was carried out in connection with the start of the RT and the second interview two weeks after completion of the RT. Before each interview, written informed consent was obtained from all participants, except children younger than 15 years, who gave their verbal assent and whose parents gave their written informed consent

The first interview began with a clarification of the purpose of the interview and an opportunity for the participant to ask further questions. Then the interviewer asked an open question: "Can you tell me about when you found out that you/your mother/your wife had breast cancer?" The participants were asked to freely narrate their lived experience when a family member is diagnosed with breast cancer, and additional questions, such as "How did it feel? Could you describe ... ? What was it like?", were asked for the sake of clarification and in order to promote conversation. An interview guide can be used to reach greater depth in interviews, cover areas of interest, and enable a more free conversation (Patton, 2002). Thus, by reviewing the literature in the field and after a thorough discussion among the authors, a guide was developed consisting of the following areas of interest: family life, daily life, and physical and emotional aspects. The interviewer (AHH) tried to balance the interview by sharing the silences that arose and waiting for the participant to proceed. Moreover, the interviewer was especially attentive and responsive to how the children perceived the situation, endeavouring to use a language that was easy to understand, as well as explaining, without being directive, if the child did not seem to understand.

The second interview began with a summary of the participants' own narrative from the previous interview, and then the participants were asked to freely narrate and reflect on their lived experience when a family member is diagnosed with breast cancer. The interviews were conducted in the participants' homes ( $n=5$ families), in the evening, and at the RT department in the daytime ( $\mathrm{n}=1$ family).

\subsection{Data analysis}

The analysis began during the interviews, where the first author listened and paid attention to the meaning of each participant's narrative. All interviews were transcribed verbatim, and notations were made about additional interview features, such as voice inflection, silence, and onset of crying. The first and fourth author independently read and reread all family members' transcripts to obtain an understanding of the overall text. They then conducted independent analyses of the transcripts using a line-by-line approach influenced by van Manen (2001). Each sentence or cluster was explored in order to find out what it revealed about the meaning of living as a family when a member of the family is diagnosed with breast cancer. These sentences were then highlighted and tentative theme designations written down, and the analysis continued with the authors comparing each family member's narrative with those of the rest of the family, as well as with the narratives of the other families. The family members' descriptions were organised and summarised into an overall theme and subthemes, and the analysis moved back and forth between the subthemes and the overall theme. All authors discussed the essence of the theme and the subthemes, as well as their variations, in order to generate a deeper insight into the family's experience as a unit as well as each family member's experience. A thorough procedure of writing and re-writing took place, the authors being fully focused on the phenomenon of interest in order to elucidate families' lived experience when a family member is diagnosed with breast cancer.

\subsection{Preunderstanding}

Before initiating the study, the first and fourth authors tried to make their preunderstanding in oncology nursing explicit in order to avoid predisposed interpretations of the phenomenon under study. As van Manen (2001) states, it is better to be deliberately aware of one's assumptions, beliefs, and theories, throughout the research process, than to forget them. Thus, making one's preunderstanding explicit may prevent the researchers' knowledge from influencing the analysis process in a subjective manner. All the authors have experience of doing qualitative research and performing interviews. Furthermore, the second author has great expertise in care science and clinical science, and the third and fourth author have extensive knowledge of and skills in performing qualitative research.

\subsection{Ethical considerations}

The participants were informed, in accordance with the Declaration of Helsinki (World Medical Association, 2013), that participation was voluntary and could be terminated at any time without any negative consequences. They were also assured that confidentiality would be respected throughout the research process. The families were given time to discuss the study and their participation, at home, and were informed that a parent could be present during the interviews with the child. In order to minimise the intrusion in their life, each family decided the time and location for the interviews. The interviewer gave the families a card with contact information to a counsellor at the clinic for further support if they were emotionally affected due to participating. When presenting the results, great efforts were made to maintain confidentiality by carefully weighing the use of informative yet non-identifiable quotations in the text. The Regional Ethical Review Board in Lund approved this study (Reg.no. 2013/589).

\section{Rigor of the study}

According to Lincoln and Guba (1985), there are four criteria for establishing trustworthiness in a qualitative study, namely, credibility, transferability, dependability, and confirmability. Efforts were made, throughout the whole research process, to enhance the trustworthiness. Children are considered less articulate than adults, which is why individual interviews are recommended when performed with children, as this allows their statements to be heard and not overruled by the parents' voices (Miles and Huberman, 1994). Thus, all family members were interviewed individually, to enhance the credibility of the findings by allowing each member to expose her or his thoughts without consideration for the other family members' opinions. To create an open atmosphere and ensure that the participants felt secure and comfortable, the interviews took place in the order selected by the family members themselves. Although the main aim of conducting the conversational interviews was to elucidate families' lived experience, a therapeutic aspect seemed to arise during most of them. The families expressed that these kinds of conversations should be offered to all families when a member is diagnosed with breast cancer. Heterogeneity among the participants also supports the credibility, as the data were gathered from families who varied in terms of structure, age, and living conditions. Further, the analysis of the data was performed independently by the first and fourth author and then discussed within the author team.

The transferability of the findings was enhanced through a description of the participants in text and by adding a table. All participants diagnosed with breast cancer in this study were at the same poin in time in their illness trajectory, that is, when the woman in the family was receiving and completing her radiotherapy treatment. The dependability of the study was strengthened by the attempt to obtain a genuine understanding and clarification of what was being said during the interview. In order to enhance the dependability of the study, the 
first author conducted all interviews, although all the authors listened to the recorded interviews when performed to ensure that the relevant areas of interest were covered and to strengthen the quality of the subsequent interviews. Furthermore, in order to increase confirmability clear descriptions of each stage of the research process were provided and quotations from the interview transcripts presented.

\section{Results}

The families' lived experience could be described metaphorically. It was as if they found themselves on a boat offshore on a dark and cloudy night trying to row their way back to dry land, hoping to reach a safe haven. The families experienced the illness and treatment as a darkness that had to be conquered in order to reach the ordinary, safe life that they had lost. They found it hard to navigate, since they were fumbling in the dark, and did not know where they were or in what direction they were going. The family members tried to row together, but not knowing the direction to the shore they sometimes rowed in opposite directions. When pursuing balance they tried to steer clear of reefs, which appeared in the form of treatment-related side effects, as well as trying to avoid being swamped by a giant wave, in the shape of a sudden surge of overwhelming emotions. They asked for assistance and support from people in other boats, but the assistance was sometimes associated with a fear of sinking and losing control of their boat. The families did their utmost to maintain their hope of pulling through, but were struggling with guilt and inadequacy, which threatened their return to dry land as a family. Thus, all family members tried to make sure, and reassure each other, that the family would reach a safe haven.

\subsection{Fumbling in the dark}

The families' life situations changed after the breast cancer diagnosis, which sent them out into the unknown darkness. They felt that they were stuck with old charts that were not reliable as they tried to find their way back to safety and control. Life as they knew it had disappeared together with their usual, familiar roles and functions. They did not know how or where to seek help and support, or if anyone could guide them on their path to terra firma. Obstacles and problems arising ahead of them made the family members cling to each other. The families were concerned about their present situation as well as about what the future would bring them, which made them both long for and dread the future. Family life became a long wait characterised by insecurity and ignorance, and by a need of information regarding the illness, the treatment, and the side effects and outcomes of the treatments.

The women with breast cancer expressed that living in uncertainty left them with feelings of horror and despair, and they feared that the family would never be safe again. The uncertain view of the future forced them to confront their own mortality. They strove towards safety and ordinary domesticity, though with an unmet need of support and guidance. "Yes, one waits, but a person who's in shock doesn't ask for anything, because one doesn't know what to ask for." The uncertainty made them question their ability to manage the situation and hold the family together.

The husbands felt as if their life fell apart, as if everything was upside down and insecure in their life. The uncertainty made it hard to focus and concentrate and it left them with fragmented minds. They did not know how to best support their family. "If you assemble all the pieces of a jigsaw puzzle, there will be a big puzzle, but you know, in order to make a big jigsaw puzzle you have to add one piece after the other. It's not something you do just like that: now it's done! Instead you take one piece, and then another. And we're in the midst of it; the jigsaw puzzle isn't finished yet, there're still many pieces left." Although feeling a need to stay in control and bring the family to safety, the husbands had to accept facing the unknown and continue their fumbling in the dark.
The children's unpredictable existence affected them negatively both at home and in school. They became preoccupied with the outcomes of their mother's treatment, dreading that she would not survive. They lived in ever-present fear of their mother being struck by illness, complications, and treatment-related side effects, which made them constantly check her whereabouts: "Sometimes when you come home and she's not at home, you call her directly and ask: What are you doing?" The children found it hard to focus on their school assignments, which sometimes affected their marks negatively. Living in uncertainty made them reminisce about their ordinary life: "You know, although I may not have liked my normal life, I still want that life more than I wanted things to be like this." The children's need for certainty and safety was prominent, and one girl said with longing in her voice: "I long for us to sit there in the caravan and for everything to be as usual."

\subsection{Pursuing balance}

The families struggled to manage their unsteady journey to safety without capsizing. The family members tried to keep each other safe, and put the wellbeing of the others before their own. Family and friends also came to their rescue, which could be lifesaving but sometimes almost tipped the boat over. The families made efforts to try to look positively on the future and their possibility to reach dry land, although obstacles, such as treatment-related side effects, forced them to take one day at a time. Keeping the family together while moving forward to safety, despite the intrusion of the illness, was a united but strenuous effort.

The women with breast cancer struggled to maintain a facade in front of the family, trying to protect the children by concealing distress and treatment-related side effects when managing their fragile life situation. They felt that availability and continuity among healthcare professionals helped them to stay on top of their situation, although unmet support needs concerning the wellbeing of their family made the women with feel abandoned. Trying to stay positive and optimistic about the future, although hard, was a top priority: "I have to enjoy being well now. I can't keep worrying, because then these days won't be good days." The emotional and instrumental support received from parents and friends was appreciated: "I don't know what I would have done without that lifeline; I think I would have gone mad," at the same time as the women with breast cancer fought hard to take care of their family.

The husbands experienced life as a balancing act, where they felt that they had to lead the way forward through the crisis. They tried to focus on the possibilities and on the thought that somehow they were going to make their way out of the darkness. "I'm not ill but I'm still affected. It's hard to relate to and difficult to talk about. There isn't really anyone that you can talk to; I can't really talk to X [the wife] about it either, because after all someone must ... look forward, or appear to ... 'Come on, now'. But at the same time, I'm there too. It's quite a difficult balancing act because I can never really be myself in this, do you see what I mean?" They tried to support and encourage their wife, knowing that when she was feeling better it affected the whole family positively.

The children all expressed that getting to spend more time at home with their mother helped them to manage the chaotic situation: "It's been good having mum at home more often.” The increased closeness between the siblings, and in the family overall, also helped them to adjust and provide leverage against the insecurity that they felt. However, the children needed school and the space outside their home to be sanctuaries free from the intrusion of illness. They wanted the teachers to be aware of and pay attention to their situation and yet they most of all wanted to be treated as usual. Their mother's different treatments were seen as obstacles that they checked off on a list, moving forward towards life as they knew it and wanted it to be. 


\subsection{Struggling with guilt and inadequacy}

The families were often disappointed with themselves as well as feeling let down by other persons in their vicinity and left drifting alone at open sea. They felt that their existence depended on their own capability, and they were concerned about the lack of understanding and support from healthcare professionals and school. This led to a recurring sense of disappointment and was experienced as a threat to their return to safety. Although the family members wanted their family to be seen as a unit, they also longed for their ordinary life where they enjoyed more space as individuals. Their difficulties in sharing and communicating the family burden that the illness brought upon them led to self-reproach and feelings of guilt.

The changed roles and responsibilities accentuated the vulnerability of the women with breast cancer, as they felt they could no longer protect their family. They also felt responsible for bringing illness and sadness to the family, which made them question their former life and life style. Although aware of living healthy lives with good eating habits and exercise, they all felt that they maybe could have lived an even more healthy life. They berated themselves for not being able to stay on top of the situation or shield their family. The women with breast cancer tried to hide their sadness and worry: "You don't necessarily talk about these deep feelings that ... Fear of death ...," but at the same time they were aware that the family would benefit from an open communication.

The husbands wanted to carry the burden of illness and treatment for their wife but were struck by feelings of inadequacy. They also blamed themselves for not being able to protect and care for their family to the extent desired. They struggled to assist their wife in managing side effects: "I was so nervous, and that was difficult ... [about helping his wife to empty the drains after the surgery]," trying to learn and manage unfamiliar tasks. Moreover, they expressed an unmet need of being seen and supported by the healthcare professionals.

The children felt guilty and inadequate, as they wanted to live their ordinary life with friends and engage in fun activities despite their mother's illness. They were torn between their friends and doing what they felt was the right thing, namely, being with their family: "The hardest thing for me has probably been that I've had [lowers voice] feelings of guilt and such ... Sometimes maybe mum has become sad when I've been about to leave, but I do want to go out with my friends, yet of course at the same time I want to be home." The children also felt that they sometimes forgot or just did not have the strength to acknowledge their mother's illness: "The worst thing was coming home from school and perhaps having had a tough day and then mum wasn't feeling well and was very tired ... yes, that was hard, of course; it was difficult to know what to do." Not knowing how to help and support their mother made the children challenge and confront her, leaving them sad and disappointed with the whole situation.

\section{Discussion}

The discussion of the findings will be guided by the four existential dimensions described by van Manen (2001) including the lived body, lived time, lived human relations and lived space.

\subsection{Lived body}

The lived body relates to how a person is always corporeally in the world and to the fact that it is through her bodily appearance that she first meets other persons (van Manen, 2001). The dimension lived body is intertwined with the management of the physical side effects of the disease and treatment as well as the fight for survival. Thus, the bodily appearance of the woman diagnosed with and treated for breast cancer, was experienced as changed, which had consequences and significance not only for herself but also for other persons close to her and, not least, for the children. The family members' awareness of the woman's bodily weakness and suffering led to a struggle to relieve and assist her. This awareness could, however, also make the children scared, since every bodily change in their mother meant a threat to her existence as well as a constant reminder that their ordinary life had disappeared. The family's life world was transformed into one of uncertainty and disintegration, which led them on a quest to regain safety and ordinary life. The uncertainty made the families in our study spend more time together, trying to be "bodily" near each other and putting the wellbeing of the other before their own while running the gamut of emotions from hope to despair.

The importance of gathering and being close to each other has also been shown in research elucidating families' adaptation during and after a family member's hospitalisation in an intensive care unit (Söderström et al., 2009).

\subsection{Lived time}

Lived time (temporality) is referred to as subjective time, as opposed to clock or objective time. The way the afflicted families in our study described this dimension indicated that they experienced the breast cancer as an intruder that took them away from their ordinary, safe life and prevented them from returning to life as they knew it. They glorified their ordinary life and just wanted to turn back time to before the illness, feeling that they were stuck in the illness, unable to move forward. They feared the future and could only take one day at a time. Living as a family in the presence of breast cancer meant an abrupt awareness of the fragility of life, and lived time meant reflections on the past and a reevaluation of life as a whole, while striving to find balance and safety again. The families were eager to revert to their happy domesticity and the time before the illness struck, where life was experienced as safe and ordinary. Returning to ordinary, everyday life was the main priority for both the family members as individuals and the family as a unit. Families struggle to reconstruct their daily life when a family member is struck by illness has also been shown in research elucidating families experiences when a family member is diagnosed with chronic illness (Årestedt et al., 2014).

\subsection{Lived human relations}

The families' lived relation revealed itself as altered roles and functions. The family members sought shelter within the family but tried to seek help outside the family as well. While striving to relieve the afflicted woman's suffering, all the family members also attempted to protect and shield each other from the powerful emotions caused by the experience. The families' lived relation became stronger but at the same time more fragile, since they did not know how to act in relation to each other when life as they knew it had disappeared. The family members' struggle with feelings of guilt and self-reproach tended to become a downward spiral towards deteriorating communication and increased alienation. Their conflicting feelings of increased closeness and alienation show the complexity in living as a family in the presence of illness. Altered relationships have also been described in families facing chronic illness in a family member (Årestedt et al., 2014), and cancer patients and their partners have expressed that the diagnosis of cancer changed their relationship negatively, which led to increased psychological distress and decreased quality of life (Drabe et al., 2013). For the families in this study, the relationship within the family became strained, since the family members struggled with their own individual beliefs regarding the prognosis of the illness, and their expected roles and functions. The families' difficulties in communicating their emotional distress and their feelings of abandonment suggest that healthcare professionals should invite and include the whole family in the care of the ill family member. Healthcare professionals should explore the family's knowledge and beliefs about breast cancer repeatedly during the treatment trajectory in order to individualise information and support, as well as giving psychosocial support that will help the 
families recognise their own power and find their direction. Further, when elucidating the lived experience of men diagnosed with prostate cancer (Krumwiede and Krumwiede, 2012) and of women with breast cancer experiencing cognitive side effects (Kanaskie and Loeb, 2015), it was shown that healthcare professionals were seen as the trusted connection and a way to move forward. Overall, healthcare professionals could, by providing accurate tools for managing health adversities, ease the families' suffering and anguish as well as increasing their wellbeing.

\subsection{Lived space}

Lived space revealed itself within the families as the psychological space of uncertainty, vulnerability, and ignorance that they occupied when living as a family in the presence of breast cancer. They felt lost and all alone in the universe while struggling to overcome this by joining forces to revert to ordinary domesticity. The psychological space the families occupied was constantly rearranged, due to the side effects of the women's medication and other unexpected events, and the ensuing vulnerability forced the family members to expose aspects of themselves that they did not recognise. Grappling with new sides of their identity further fuelled their vulnerability and uncertainty. Lived space as a life in the unknown was also seen in women with breast cancer struggling with cognitive side effects of chemotherapy (Kanaskie and Loeb, 2015). Struggling with new sides of their identity further fuelled their vulnerability and uncertainty. When struck by illness, like cancer, the patient and the other family members tend to maintain their function as a unit, trying to respond to the challenge and endeavouring to adjust their roles (Walsh et al., 2005). However, families diverge in their ability to preserve stability in the face of shifting roles and functions during adverse events and achieve differing levels of adjustment to the new situation (Northouse et al., 2005). The constant feeling of uncertainty also hampered the families' ability to communicate openly. Their endeavour to shield each other from any extra burden, and the subsequent withholding of emotions, are in line with the findings of Coyne et al. (2012), where the families concealed their distress and postponed their request for support until their emotional situation was unbearable. Vannatta et al. (2010) emphasised that healthcare professionals need to recognise the need of family support as well as families' ability to share emotions and manage difficulties, in order to create tools for improving psychosocial function in families affected by cancer. Huizinga et al. (2003) also emphasised the need for healthcare professionals to encourage and support an open communication style within the family, in order to facilitate family cohesion and coping.

\subsection{Limitations of the study}

All families were native Swedes, which may be seen as a limitation. There is a possibility that families born outside Sweden could have experienced the phenomenon differently, since the experience of illness may be influenced by cultural identity and values regarding, for example, the meaning of illness, the relationship with healthcare professionals, and the preferred type of care (Bäärnhielm and Ekblad, 2008; Surbone, 2008).

\section{Conclusions}

Living as a family when the mother in the family is diagnosed with breast cancer means living in a challenging, rearranged, and unknown reality, while struggling to regain ordinary life. This study affirms that a breast cancer diagnosis in the family is a strenuous experience that affects the entire family, and may lead to family relationship challenges. Moreover, the study shows that families of women with breast cancer need information, support, and guidance from healthcare professionals to help them endure and cope with the distressing experience.

\subsection{Clinical implications}

The findings of this study assert the need for healthcare professionals to see the woman with breast cancer in her context. Healthcare professionals may include families already at the time of the diagnosis and support them during the treatment trajectory and beyond, in order to increase their wellbeing as well as empowering them.

\subsection{Directions for future research}

This study confirms that breast cancer affects all family members in many ways, and it shows the need to develop and test tailored interventions that meet the needs of families impacted by cancer, in order to determine what works, and for whom, and when it should be implemented during the cancer trajectory. Further, it shows that healthcare professionals need to identify the families that are at the greatest risk of poor adjustment. The families' experience of living in uncertainty during the whole treatment trajectory, and even after active treatment is finished, indicates insufficient support and guidance from the healthcare professionals. There seems to be a need for research that includes the whole family in interventions aiming at increasing openness, connectedness, and trustfulness in caring relationships, in order to facilitate an open communication within the family. Furthermore, since the families also received support from relatives outside the nuclear family, like the woman's parents, there may be a need for elucidating, for example, the parents' experiences when an adult daughter is diagnosed with breast cancer.

\section{Conflicts of interest}

The authors report no conflicts of interest.

\section{References}

Adams, E., McCann, L., Armes, J., Richardson, A., Stark, D., Watson, E., Hubbard, G., 2011. The experiences, needs and concerns of younger women with a breast cancer: a meta- ethnography. Psycho-Oncology 20, 851-861. http://dx.doi.org/10.1002/pon. 179

Årestedt, L., Persson, C., Benzein, E., 2014. Living as a family in the midst of chronic illness. Scand. J. Caring Sci. 28, 29-37. http://dx.doi.org/10.1111/scs.12023.

Arora, N.K., Rutten, F., Gustafson, D.H., Moser, R., Hawkins, R.P., 2007. Perceived helpfulness and impact of social support provided by family, friends, and health care providers to women newly diagnosed with breast cancer. Psycho-Oncology 16, 474-486. http://dx.doi.org/10.1002/pon.1084.

Asbury, N., Lalayiannis, L., Walshe, A., 2014. How do I tell the children? Women's experiences of sharing information about breast cancer diagnosis and treatment. Eur. J. Oncol. Nurs. 18, 564-570. http://dx.doi.org/10.1016/j.ejon.2014.07.003.

Bäärnhielm, S., Ekblad, S., 2008. Introducing a psychological agenda for understanding somatic symptoms-an area of conflict for clinicians in relation to patients in a multicultural community. Cult. Med. Psychiatry 32, 386-405. http://dx.doi. arg $/ 10$ 1007/s11013-008-9100-8.

Belcher, A.J., Laurenceau, J.P., Graber, E.C., Cohen, L.H., Dasch, K.B., Siegel, S.D., 2011. Daily support in couples coping with early stage breast cancer: maintaining intimacy Daily support in couples coping with early stage breast cancer: maintaining intin
during adversity. Health Psychol. 30 (6), 665-673. http://dx.doi.org/10.1037/ during adversit

Belmont, J.M., 1989. Cognitive strategies and strategic learning. The socio-instructional approach. Am. Psychol. 44, 142-148. http://dx.doi.org/10.1037/0003-066X.44.2. 142 .

Clemmens, D.A., 2009. The significance of motherhood for adolescents whose mothers have breast cancer. Oncol. Nurs. Forum 36 (5), 571-577. http://dx.doi.org/10.1188 09. ONF.571-577.

Coyne, E., Wollin, J., Creedy, D.K., 2012. Exploration of the family's role and strength after a young woman is diagnosed with breast cancer: views of women and their family. Eur. J. Oncol. Nurs. 16, 124-130. http://dx.doi.org/10.1016/j.ejon.2011.04. 013

Drabe, N., Wittman, L., Zwahlen, D., Büchi, S., Jenewein, J., 2013. Changes in close relationships between cancer patients and their partners. Psycho-Oncology 22 , 1344-1352. http://dx.doi.org/10.1002/pon.3144.

Duggleby, W., Doel, H., Cooper, D., Thomas, R., Ghosh, S., 2013. The quality of life of male spouses of women with breast cancer: hope, self-efficacy, and perceptions of guilt. Cancer Nurs. http://dx.doi.org/10.1097/NCC.0b013e31827ca807.

Dukes, S., 1984. Phenomenological methodology in the human sciences. J. Relig. Health 23 (3), 197-203.

Edwards, L., Watson, M., St James-Roberts, I., Ashley, S., Tilney, C., Brougham, B. Romer, G., 2008. Adolescent's stress responses and psychological functioning when a 
parent has early breast cancer. Psycho-Oncology 17, 1039-1047. http://dx.doi.org/ 10.1002/pon.1323.

Fletcher, K.A., Lewis, F.M., Haberman, M.R., 2010. Cancer-related concerns of spouses of women with breast cancer. Psycho-Oncology 19, 1094-1101. http://dx.doi.org/10. 1002/pon.1665.

Fu, M.R., Xu, B., Liu, Y., Haber, J., 2009. 'Making the best of it': Chinese women's experiences of adjusting to breast cancer diagnosis and treatment. J. Adv. Nurs. 63 (2), 155-165. http://dx.doi.org/10.1111/j.1365-2648.2008.04647.x.

Guest, G., Bunce, A., Johnson, L., 2006. How many interviews are Enough? An experiment with data saturation and variability. Field Methods 18 (1), 59-82. http://dx doi.org/10.1177/1525822X05279903.

Hodgkinson, K., Butow, P., Hunt, G.E., Wyse, R., Hobbs, K.M., Wain, G., 2007. Life after couples' and partners' psychological adjustment and supportive care needs. Support couples' and partners' psychological adjustment and supportive care needs.
Care Cancer 15, 405-415. http://dx.doi.org/10.1007/s00520-006-0148-0.

Huang, X., O'Connor, M., Lee, S., 2014. School-aged and adolescent children's experience when a parent has non-terminal cancer: a systematic review and meta- synthesis of when a parent has non-terminal cancer: a systematic review and meta- synthesis of
qualitative studies. Psycho-Oncology 23, 493-506. http://dx.doi.org/10.1002/pon.

3457.

Huizinga, G.A., van der Graaf, W.T., Visser, A., Dijkstra, J.S., Hoeckstra-Weebers, J.E. 2003. Psychosocial consequences for children of a parent with cancer: a pilot study. Cancer Nurs. 26, 195-202.

Kanaskie, M.L., Loeb, S.J., 2015. The experience of cognitive change in women with breast cancer following chemotherapy. J. Cancer Surviv. 9, 375-387. http://dx.doi. org/10.1007/s11764-014-0387-x.

Krattenmacher, T., Kühne, F., Ernst, J., Bergelt, C., Romer, G., Möller, B., 2012. Parental cancer: factors associated with children's psychosocial adjustment - a systematic review. J. Psychosomatic Res. 72, 344-356. http://dx.doi.org/10.1016/j.psychores. 2012.01.011.

Krumwiede, K.A., Krumwiede, N., 2012. The lived experience of men diagnosed with prostate cancer. Oncol. Nurs. Forum 39 (5), E443-E450.

Lebel, S., Beattie, S., Ares, I., Bielajev, C., 2013. Young and worried: age and fear of recurrence in breast cancer survivors. Health Psychol. 32 (6), 695-705. http://dx.doi. org/10.1037/a0030186.

Lewis, F.M., Fletcher, K.A., Cochrane, B.B., Fann, J.R., 2008. Predictors of depressed mood in spouses of women with breast cancer. J. Clin. Oncol. 26 (8), 1289-1295. http://dx.doi.org/10.1200/JCO.2007.12.7159.

Lincoln, Y.S., Guba, E.G., 1985. Naturalistic Inquiry. Sage Publications, Beverly Hills.

Lopez, V., Copp, G., Molassiotis, A., 2012. Male caregivers of patients with breast and gynecologic cancer: experiences from caring for their spouses and partners. Cancer gynecologic cancer: experiences from caring for their spouses and partners.
Nurs. 35 (6), 402-410. http://dx.doi.org/10.1097/NCC.0b013e318231dafo.

Miles, M.B., Huberman, A.M., 1994. Qualitative Data Analysis: an Expanded Sourcebook. Sage Publications, Thousand Oaks, CA.

Sage Publications, Thousand Oaks, CA.
Morse, J.M., 2000. Determining sample size. Qual. Health Res. 10 (1), 3-5.

Morse, J.M., 2000. Determining sample size. Qual. Health Res. 10 (1), 3-5.

psychosocial dysfunction among family caregivers of patients with advanced cancer.
. psychosocial dysfunction among family caregivers of patients with adva
J. Pain Symptom Manag. 52 (6), 841-849. http://dx.doi.org/10.1016/j J. Pain Symptom Manag. 52

jpainsymman.2016.07.006.
Northouse, L., Kershaw, T., Mood, D., Schafenacker, A., 2005. Effects of a family interverthouse, L., Kershaw, T., Mood, D., Schafenacker, A., 2005. Effects of a family inter-
vention quality of life of women with recurrent breast cancer and their family caregivers. Psycho-Oncology 14 (6), 478-491. http://dx.doi.org/10.1002/pon.871.

Patton, M.Q., 2002. Qualitative Research \& Evaluation Methods, third ed. Sage, London.

Piaget, J., 1972. Intellectual evolution from adolescence to adulthood. Hum. Dev. 157-164. Retrieved April 10, 2016. http://www.fondationjeanpiaget.ch/fjp/site/ textes/VE/JP70_Evolut_Intellect_Adoles_Adulte.pdf.

Robbins, M.L., Mehl, M.R., Smith, H.L., Weihs, K.L., 2013. Linguistic indicators of patient, couple, and family adjustment following breast cancer. Psycho-Oncology 22, 1501-1508. http://dx.doi.org/10.1002/pon.3161.

Schmid-Büchi, S., Halfens, R.J.G., Dassen, T., van den Borne, B., 2011. Psychosocial problems and needs of post treatment patients with breast cancer and their relatives. Eur. J. Oncol. Nurs. 15, 260-266. https://doi.org.proxy.mah.se/10.1016/j.ejor 2009.11.001

Schmid-Büchi, S., Halfens, R.J.G., Müller, M., Dassen, T., van den Borne, B., 2013. Factor associated with supportive care needs of patients under treatment for breast cancerEur. J. Oncol. Nurs. 17, 22-29. http://dx.doi.org/10.1016/j.ejon.2012.02.003.

Schubart, J.R., Emerich, M., Farnan, M., Smith, J.S., Kauffman, G.L., Kass, R.B., 2014 Screening for psychological distress in surgical breast cancer patients. Ann. Surg. Oncol. http://dx.doi.org/10.1245/s10434-014-3919-8.

Semple, C.J., McCance, T., 2010. Experience of parents with head and neck cancer who are caring for young children. J. Ady. Nurs. 66, 1280-1290. http://dx.doi.org/10. 1111/j.1365-2648.2001.05311.x.

Siegel, R., Naishadham, D., Jemal, A., 2013. Cancer statistics 2013. CA: A Cancer J. Clin. 13 (63), 11-30. http://dx.doi.org/10.3322/caac.21166.

Sjövall, K., 2011. Living With Cancer - Impact on Cancer Patient and Partner. Lund University Faculty of Medicine Doctoral Dissertation Series 2011:25.

Söderström, I.M.K., Saveman, B.I., Hagberg, M.S., Benzein, E.G., 2009. Family adaptation in relation to a family member's stay in the ICU. Intensive Crit. Care Nurs. 25, 250-257. https://doi.org. proxy.mah.se/10.1016/j.iccn.2009.06.006.

Sprung, B.R., Janotha, B.L., Steckel, A.J., 2011. The lived experience of breast cancer patients and couple distress. J. Am. Acad. Nurse Pract. 23 (11), 619-627. http://dx doi.org/10.1111/j.1745-7599.2011.00653.

Stenberg, U., Ruland, C.M., Miaskowski, C., 2010. Review of the literature on the effects of caring for a patient with cancer. Psycho-Oncology 19, 1013-1025. http://dx.doi. org/10.1002/pon.1670.

Stinesen Kollberg, K., Thorsteinsdottir, T., Wilderäng, U., Steineck, G., 2013. Worry abou one's own children, psychological wellbeing, and interest in psychosocial intervention. Psycho-Oncology 22, 2117-2123. http://dx.doi.org/10.1002/pon.3266.

Surbone, A., 2008. Cultural aspects of communication in cancer care. Support. Care Cancer 16, 235-240. http://dx.doi.org/10.1007/s00520-007-0366-0.

van Manen, M., 2001. Researching Lived Experience: Human Science for an Action Sensitive Pedagogy, second 2 ed. Althouse press, Ontario.

Vannatta, K., Grollman, J.A., Noll, R.B., Gerhardt, C.A., 2008. Impact of maternal breast cancer on the peer interactions of children at school. Psycho-Oncology 17 (3), 252-259. http://dx.doi.org/10.1002/pon.1232.

Vannatta, K., Ramsey, R.R., Noll, R.B., Gerhardt, C.A., 2010. Associations of child adjustment with parent and family functioning: comparison of families of women with and without breast cancer. J. Dev. Behav. Pediatr. 31 (1), 9-16. http://dx.doi.org/10. 1097/DBP.0b013e3181c82a44.

Wagner, C.D., Bigatti, S.M., Storniolo, A.M., 2006. Quality of life of husbands of women with breast cancer. Psycho-Oncology 15, 109-120. http://dx.doi.org/10.1002/pon. 928.

Walsh, S.R., Manuel, J.C., Avis, N.E., 2005. The impact of breast cancer on younge women's relationship with their partner and children. Fam. Syst. Health 23 (1), 80-93. http://dx.doi.org/10.1037/1091-7527.23.1.80

Weaver, K.E., Rowland, J.H., Alfano, C.M., McNeel, T.S., 2010. Parental cancer and the family: a population-based estimate of the number of US cancer survivors residing with their minor children. Cancer 116, 4395-4401. http://dx.doi.org/10.1002/cncr. 25368.

World Medical Association, 2013. Declaration of Helsinki - Ethical Principles for Medica Research Involving Human Subjects. Retrieved May 30, 2016, from. www.wma.net/ en/30publications/10policies/b3/.

Wright, L.M., Leahey, M., 1994. Calgary family intervention model: one way to think about change. J. Marital Fam. Ther. 20, 381-395. http://dx.doi.org/10.1111/j.1752 0606.1994.tb00128.x.

Wright, L.M., Leahey, M., 2013. Nurses and Families. A Guide to Family Assessment and Intervention, sixth ed. F.A. Davis Company, Philadelphia, PA. 

IV 

The experiences of participating in Short Family Health Conversations from the perspective of families where a family member is diagnosed with breast cancer

\section{(Original Article)}

Authors:

Annette Holst-Hansson, ${ }^{1,2}$ RN, MSc, PhD student

Vedrana Vejzovic, ${ }^{1}$ RN, RSCN, PhD

Ewa Idvall, ${ }^{1} \mathrm{RN}, \mathrm{PhD}$, Professor

Ingrid Bolmsjö, ${ }^{1}$ BTh, Professor

Anne Wennick, ${ }^{1}$ RN, RSCN, PhD

${ }^{1}$ Malmö University, Faculty of Health and Society, Department of Care Science, Malmö, Sweden

${ }^{2}$ Lund University, Health Sciences, Integrative Health Research, Lund, Sweden

Corresponding author and to whom offprint should be sent: Annette Holst-Hansson, Address:

Faculty of Health and Society, Department of Care Sciences, SE-205 06 Malmö, Sweden, Telephone: +46 7627267 99, Fax number: +46 4066581 00, E-mail:

annette.holst.hansson@mau.se 


\begin{abstract}
A breast cancer diagnosis in a family member is a stressful experience that affects the entire family, which indicates a need for interventions with a family approach. The aim of this study was to explore families' experiences of participating in Short Family Health Conversations (SFamHC) following a breast cancer diagnosis. Nine families where the woman was diagnosed with breast cancer and receiving radiotherapy were included in the study. Each family had participated in three sessions of SFamHC influenced by the theoretical framework of Family Systems Nursing. Family interviews were conducted with the families two weeks after the last SFamHC and were analyzed by means of thematic content analysis. The families experienced the SFamHC as a different kind of conversation that affected them positively. Family members described how the SFamHC provided them with an opportunity to verbalize and share their feelings and thoughts. They also experienced a confirmation of their strengths and resources as a family at the same time as their participation in the SFamHC helped them to move forward and beyond the breast cancer diagnosis. Family members felt that their participation facilitated relational sharing and meaningful conversations, which suggests that supportive conversations like SFamHC can be suitable as a family approach following breast cancer.
\end{abstract}

Keywords: breast cancer; family-focused care; family health conversations; family interview; family systems nursing; radiation therapy; Swedish families 
A family where a family member is diagnosed with breast cancer often faces great challenges and experiences multifaceted needs (Coyne, Wollin, \& Creedy, 2012; Northouse, Williams, Given, \& McCorkle, 2012; Robbins, Mehl, Smith, \& Weihs, 2013). The diagnosis may affect the ways the family members engage with each other, communicate, and interact, as well as their roles, family functioning, and well-being (Coyne et al., 2012; Dieperink, Coyne, Creedy, \& Östergaard, 2017). Despite the strain that breast cancer in a family member put on the family as a unit, families seldom feel that their needs as a family are seen or met by the health care professionals (Coyne, Grafton, Reid, \& Marshall, 2017). However, research is starting to better comprehend the needs of families where a family member is diagnosed with breast cancer and to consider the family as a unit that includes both the patient and the family members (Dieperink et al., 2017). If the family is able to maintain a healthy family functioning, they might be better at managing stressors and difficulties (Epstein, Bishop, \& Levin, 1978; Kaakinen \& Denham, 2015), like a breast cancer diagnosis and its subsequent treatment. Previous research indicates that women and their family members require encouraging and open communication as well as collaborative support from health care professionals following a breast cancer diagnosis (Coyne et al., 2012; Robbins, Lopez, Weihs, \& Mehl, 2014; Stinesen-Kollberg, Thorsteinsdottir, Wilderäng, \& Steineck, 2013). It also emerges from previous research that there seems to be a need for understanding relationship vulnerabilities, communication patterns, and perceived needs in accordance with the individual circumstances of those who are affected, in order to improve the well-being of both the woman with breast cancer and her family (Courney, Puthussey, \& Swinglehurst, 2016; Robbins, Lopez, Weihs, \& Mehl, 2014). 


\section{Literature review}

Research has shown that families where a family member is diagnosed with breast cancer experience difficulties in expressing and communicating emotions (Coyne et al., 2012; HolstHansson, Idvall, Bolmsjö, \& Wennick, 2017) as well as an unmet need of support from the health care professionals (Holst-Hansson et al., 2017). Further, findings from a state-ofscience review of psychosocial care for families of patients with cancer, confirmed the stressful impact a breast cancer diagnosis has on both patients and their families, resulting in changes in physical health, psychological disorders, and sleep disturbances (Northouse et al., 2012).

A systematic review of psychosocial interventions for families with parental cancer showed that interventions were considered helpful, with improvements in the participants in various outcomes (Inhestern, Haller, Wlodarczyk, \& Bergelt, 2016). The interventions were mainly aiming at improving the communication between family members and at supporting children's adaptation to and understanding of cancer, and they consisted of counseling or conversations and were either family centered or person centered (Inhestern et al., 2016). The findings also showed that the interventions have to be flexible, easy to access, and offered as a routine care to reach a broader range of families in need of support. However, the variability in study populations and intervention design makes it difficult to generalize findings from the studies (Inhestern et al., 2016). When evaluating family interventions in oncological care addressing the whole family, improvements were seen in quality of life, psychological health, and depressive symptoms in parents as well as children (John, Becker, \& Mattejat, 2013; Thastum, Munch-Hansen, Wiell, \& Romer, 2006). Further, families described how the counseling improved the communication between the family members, gave them a deeper understanding of one another's reactions and emotions, a normalization of their emotions, as well as a closer intimacy and unity within the family (Thastum et al., 2006). Satisfaction with 
the counseling was also significantly correlated with decreased depression in the parents and increased family functioning (Thastum et al., 2006). Healthy family functioning is vital in the family members' endeavor to adapt to changes and facilitate the maintenance of the family's health and well-being, and it supports physical and emotional health (Epstein et al., 1978; Ryan, Epstein, Keitner, Miller, \& Bishop, 2005). Family functioning and well-being are conceptions that are the foundation of family health (Friedman, Bowden, \& Jones, 2003), and family functioning can be defined as the ability of family members to interact, react, and respond to each other (Ryan, 2005).

Although there is an increasing awareness of the importance of assessing and acknowledging the needs of the family when they face a major shift, such as adapting to a family illness, this is often addressed both informally and unsystematically by health professionals (dos Santos Ribeiro Silva, Moules, Silva, \& Bousso, 2013).

\section{Family-focused care}

Family-focused care is grounded in the belief that health and illness in a family member affect the other family members both as individuals and as a family (Benzein, Hagberg, \& Saveman, 2008; Wright \& Leahey, 2013), and it originates from Family Systems Nursing (FSN) (Wright \& Leahey, 1994, 2013), which has its theoretical foundation in The Calgary Family Assessment Model (CFAM), the Calgary Family Intervention Model (CFIM) (Wright \& Leahey, 1994, 2013), and the Illness Belief Model (IBM) (Wright \& Bell, 2009; Wright, Watson, \& Bell, 1996). Based on a conceptualization first presented by Wright and Leahey (1990) and further developed in Sweden by Benzein and colleagues (2008, 2017), Family-focused care is guided by the interaction, relationships, and reciprocity between multiple systems levels including the diagnosis, the person with the diagnosis, the family, 
the health care professionals, and the larger systems like the health care system and society (Benzein et al., 2008, 2017; Wright \& Bell, 2009). Further, it has a systemic approach that focuses on the interactions and relationships within the family aiming to preserve health and facilitate healing. The systemic approach also means that family members' experiences and beliefs are seen as equally significant as those of the person with the diagnosis (Wright \& Leahey, 1994, 2013).

Family Health Conversations (FamHC) are a form of therapeutic conversations that are culturally adapted from the practice models of FSN (Benzein et al., 2008, 2017; Wright \& Bell, 2009; Wright \& Leahey, 1994, 2013). FamHC are offered to families with the purpose of creating a context for change in family health as well as supporting the creation of new beliefs, meanings, and relationship opportunities specific to the story narrated by the family (Benzein et al., 2008; Wright \& Bell, 2009; Wright \& Leahey, 2013). They have a family focus and begin with the family's stories (Östlund, Bäckström, Lindh, Sundin, \& Saveman, 2015). Further, FamHC have a salutogenic approach (Antonovsky, 1996) with the aim of shifting the focus of the conversation from illness and poor functioning to positive aspects and well-being (Mittelmark \& Bull, 2013), although suffering is acknowledged along with family strengths and resources (Benzein et al., 2008). FamHC are often held in a series of three conversations that last about one hour each (Benzein et al., 2008; Östlund, Bäckström, Saveman, Lindh, \& Sundin, 2016).

\section{Short Family Health Conversations (SFamHC)}

The Short Family Health Conversations (SFamHC) used in this study are a condensed form of FamHC and influenced by the "15-Minute Family Interview" developed by Wright and Leahey (1999). The reason for developing the "15-Minute Family Interview" was the recurrent concerns raised by nurses about not having enough time to involve families in 
nursing care (Wright \& Leahey, 1999), an argument that is still valid (Dieperink, 2017; dos Santos Ribeiro Silva et al., 2013).

In the first SFamHC, all family members were invited to narrate their experience of their present situation and listen to each other's stories. The first author, who is a nurse with long clinical experience of oncology, theoretical knowledge of Family Systems Nursing, and experience of family health conversations (FamHC), conducted the SFamHC in the role of conversational leader. Reflective, interventive questions (Benzein et al., 2008; Wright \& Bell, 2009; Wright \& Leahey, 2013) were posed during the SFamHC by the conversational leader, for example: "In what way are you affected as a family by X's breast cancer?", "Who in the family is most affected?", and "What is affecting how you handle the situation?". The family prioritized, in collaboration with the conversational leader, the most relevant topics to focus on. The second SFamHC focused on beliefs and problems brought up in the first conversation, while the third conversation revolved around the strengths and resources within the family as well as how these might help the family to reduce difficulties and increase wellbeing in the future. During the SFamHC, the conversational leader cooperated with each family in endeavoring to comprehend the family structure by making a genogram, as well as visualising the family's contact with the larger system through the creation of an ecomap. The conversational leader also offered reflections and commendations to the family. The SFamHC were performed in the evening in the participants' home, ranging from 15 to 40 minutes, but lasting on average 25 minutes.

\section{Rationale for this study}

More empirical studies seem to be needed in the context of families where a family member is diagnosed with breast cancer. This is emphasized by the families' experiences of a changed and stressful everyday life following a breast cancer diagnosis ( Holst-Hansson et al., 2017; 
Northouse et al., 2012), and by the positive impact families have experienced by participating in FamHC and 15-Minute Family Interviews in other contexts, for instance when a family member experiences chronic illness, cardiac and ischemic illness, depression, or childhood cancer (Bell, 2015; Benzein, Olin, \& Persson, 2014; Halldorsdottir \& Svavarsdóttir, 2012; Holtslander, 2005; Svavarsdottir \& Sigurdardottir, 2013; Sveinbjarnardóttir, Svavarsdóttir, Wright, 2013; Östlund \& Persson, 2014). More empirical studies in this area are, furthermore, especially important due to the number of women and families afflicted by breast cancer and their unmet need of support (Coyne et al., 2012; Holst-Hansson et al., 2017; John et al., 2013; Northouse et al., 2012; Thastum et al., 2006).

To our knowledge, there have been no studies exploring families' experience of participating in SFamHC following a breast cancer diagnosis.

\begin{abstract}
Aim
The aim of the study was to explore families' experiences of participating in Short Family Health Conversations (SFamHC) following a breast cancer diagnosis.
\end{abstract}

\title{
Method
}

Design

This study had a qualitative design using family interviews to explore the families' experiences of participating in SFamHC following a breast cancer diagnosis.

\section{Participants}

A total of nine families participated in this study. The inclusion criteria were Swedishspeaking families that had participated in a series of three SFamHC, with children aged 12 and older, where the woman (and mother) was diagnosed with breast cancer and about to 
receive curative radiation therapy $(\mathrm{RT})$ at a university hospital in the south of Sweden. Since children begin to develop their abstract thinking, implying, among other things, their ability to have their own complex opinions and perceive multidimensional situations, by the age of 12 (Belmont, 1989; Piaget, 1972), the lower age limit was set at 12 years. A total of 10 families who met the study's eligibility criteria were consecutively invited to participate, although one family declined participation for personal reasons. For the families accepting participation, a time and location for the interview, chosen by the family, was scheduled.

The nine included families consisted of between two and four family members; five of the families were single-parent households and four of them were married couples' households. The participating family members consisted of 13 parents (nine mothers and four fathers) and 16 children, five of whom were girls and eleven boys. The age of the mothers ranged from 43 to 56 years $(\mathrm{md}=48)$, that of the fathers from 44 to 57 years $(\mathrm{md}=48)$, that of the boys from 12 to 22 years $(m d=13)$, and that of the girls from 15 to 25 years $(m d=19)$. The mothers in the participating families had all undergone breast cancer surgery; six of them had received chemotherapy and they all received RT, for 25 days $(n=6), 20$ days $(n=2)$, and 15 days $(n=1)$.

The families had been given the Swedish version of the General Functioning Scale (SGFS) (Bylund, Årestedt, Benzein, \& Persson, 2015), and also a demographic questionnaire, before the first SFamHC. The General Functioning Scale (GFS) is a part of the wellestablished McMaster Family Assessment Device (FAD), designed to measure self-perceived general family functioning and to distinguish between healthy and unhealthy family functioning. The GFS has a cut-off score at 2, indicating perceived unhealthy family function at scores from 2 and above (Epstein, Baldwin, \& Bishop, 1983). The self-perceived general family functioning, assessed from S-GFS, ranged from 1.15 to 2.06 (mean=1.64, md=1.59), indicating that most families experienced a healthy family functioning. 


\section{Data collection}

\section{Interviews}

In order to explore the families' experiences of participating in SFamHC, semi-structured family interviews influenced by Eggenberger and Nelms (2007) were conducted by the second author (VV), two weeks after the last SFamHC. A calm, relaxed approach that focused on maintaining emphasis on the family as a whole, with acknowledgment of individual perspectives, was used during the interviews. Each interview started with a clarification of the purpose of the interview and the open question "Can you please tell me how you experienced the Short Family Health Conversations?" An interview guide was used, consisting of open questions in order to invite family members to freely narrate their experiences of SFamHC. The interview guide focused on positive and negative experiences of participating in SFamHC, their possible contribution to any changes for the family, and the family's possibility to influence the conversations. Questions were also asked about the format and the content of the SFamHC. The interviews were performed in the families' homes $(n=9)$ and they lasted for 20-45 minutes $(\mathrm{md}=29)$ and were electronically recorded for later transcription.

\section{Data analysis}

Data from the interviews was analyzed using thematic content analysis influenced by Braun and Clarke (2006). Thematic content analysis is suitable for elucidatory studies aiming at identifying, analyzing, and reporting patterns (Braun \& Clarke, 2006), as well as making interpretations of the data (Boyatzis, 1998). The analysis was made in six stages (Braun \& Clarke, 2006). The first step was to familiarize with the data and it started with the first author transcribing the interviews and making notations about additional interview features 
such as voice inflection, silence, laughter, etc. The authors read and reread all transcripts to obtain an understanding of the overall text and began to identify data relevant to the research question. The second stage in the analytic process was the coding, which was done so that the codes captured both the semantic and the conceptual reading of the data. The first and second authors independently coded every data item and ended this stage by collecting all codes in order to organize the qualitative data. In the next stage, the authors independently identified potential themes from the codes, based on patterns and clusters of meaning within the data set, keeping the aim of the research in mind. In the fourth stage, themes were reviewed together and inspected in view of ascertaining that they were accurate in relation to both the coded data and the transcripts. This stage also involved reflections on whether the themes were convincing and on the relationships between the themes. In the fifth stage, the essence of the themes was pinned down by defining and naming them. The last stage meant writing the analytic story and intertwining it with significant and representative quotes in order to present a comprehensible and credible story about the families' experience of participating in SFamHC.

\section{Ethical considerations}

The families were informed, in accordance with the Declaration of Helsinki (World Medical Association, 2013), that participation was voluntary and could be withdrawn at any time without any negative consequences. They were also assured that confidentiality would be respected throughout the research process. The families were, furthermore, given time to discuss the study and their participation at home before making their decision, and they decided the time and location for the SFamHC and the interviews in order to minimize the inconvenience in their life. Written informed consent was obtained, before the first data collection began, from all participants except children younger than 15 years, who gave their 
verbal assent and whose parents gave their written informed consent. The first author gave the families a card with contact information to a counselor at the clinic for further support if they were emotionally affected due to participating. The Regional Ethical Review Board (Reg.No. 2016/649) approved this study.

\section{Results}

The families expressed that the participation in the SFamHC was an experience that had affected them positively, albeit too late in the treatment trajectory. The participation made the families gather and review their joint journey, as a family, through the breast cancer trajectory. The families cautiously expressed that their participation in the SFamHC had made them feel stronger as a family and maybe more able to cope with future stressors and events, while being at the same time a way for them to get closure. The family members had experienced both reluctance and distress before the first SFamHC, but their initial unease was transformed into a more comfortable state during the conversations. The participation in the SFamHC also made the families feel seen and important. They felt that something had happened to them during the SFamHC, although they expressed that the effect or impression was hard to define. According to the family members, the SFamHC had helped them to verbalize their feelings and thoughts, and also given them an insight into each other's emotions, fears, and questions. Families' experiences of participating in short family health conversations (SFamHC) were identified in four key themes: Bringing everything out in the open, Being confirmed as an individual and as a family, Gaining an unexpected insight, and Timing and context matter. 
Bringing everything out in the open

The families experienced the SFamHC as a different kind of conversations that had given them an opportunity to verbalize their feelings, and they felt that some issues would not have been brought to the surface otherwise. One son said: We talked at home, yet not in that way. I think it was good to get the opportunity to sit down together and talk and get the others' perspective as well, especially mom's and dad's, what they really think. Both parents and children expressed that they had avoided verbalizing thoughts and feelings due to mutual considerations. Examples of earlier suppressed feelings and thoughts could be fear of death, and worries about the treatments and their side effects, but also uncertainty about how to communicate such feelings and thoughts. When these feelings and thoughts now could be shared it gave the family members a sense of relief. This was especially evident in the parents since they wanted to stay strong in front of their children and protect them, and one father said: What was good about the conversations was that we all of us talked about how we experienced things, but in a new way. . I didn't really dare say exactly everything to the children, but in the conversations it emerged how I had felt and what I had experienced.

Although expressing an intention to talk about their emotions and burdens in connection with the breast cancer diagnosis, the parents said that the opportunity never arose, and one mother said: So I think it's good to get help talking about this in our everyday life. You tell yourself that today I'll talk to the children, but it somehow doesn't work out like that. The SFamHC were experienced as focused, which made it easier for the family members to communicate their emotions and also their fears regarding the breast cancer diagnosis and its complications. The families expressed that they felt safer and more relaxed as they got an insight into each other's feelings and thoughts, and one father said: Children don't want to talk about what they feel, you know, they are good at pretending that everything is alright, but now I got to know. The family members expressed that they had gained extended knowledge 
of the other family members' thoughts and feelings, which meant that they no longer needed to guess and interpret, and one son said: I've learned more about how mom thinks. Now I know. I've also been able to ask the questions I had and get them answered. Moreover, the family members felt that by participating in SFamHC they were encouraged to narrate their experiences and ask questions, and invited to reflect on each other's narratives at the same time as they were given responses to reflections that had not been expressed previously.

\section{Being confirmed as an individual and as a family}

By participating in the SFamHC, the family members' understanding of each other's different experiences during the breast cancer trajectory was facilitated. The families felt seen and important, and appreciated the interest they were shown as family members and as a family. Having a person who wanted to listen to them, and who also had the knowledge to be able to answer their questions, made them feel confirmed and safe. One daughter said: It felt safe to have a person one could talk to, to ask questions if one had any and to get the time to sit down together as a family. By participating in the SFamHC, the families expressed that they received more information and gained more knowledge, which made them feel supported. One father said that he appreciated the fact that a person comes who has been there and who knows what's what, who can ask questions and get a conversation going, but also give advice and support.

The participation in SFamHC made the families aware of their capability of going through a difficult situation together, and they felt stronger as a family and as a unit. The families also felt that the extended knowledge gained during the SFamHC helped them to manage, as well as being a confirmation of how the family had dealt with the strain of the breast cancer diagnosis. The families expressed that the SFamHC gave them tools for communicating emotions and difficult issues as a family. The family members also felt that the reflections 
made by the nurse during the SFamHC gave them confirmation that their feelings and thoughts were "normal" and that there are multiple ways of experiencing a situation. The families' increased understanding of each other's thoughts and feelings reinforced and confirmed them as a family joining forces to cope with a difficult situation, and one mother said: Now that we're faced with new challenges, these three conversations have given us a seal or confirmation that ... well, that we'll cope with this too.

\section{Gaining an unexpected insight}

Some family members claimed that they had believed that they as a family were able to communicate about everything but believed that not all families had this ability. One mother said: So I suppose we haven't had that need but I suppose it's important that it exists, because there are people who are completely left to their own devices or who can't talk to each other, and that would have been terrible. Some families expressed that their reason for accepting participation in the SFamHC was mainly to help other families in the future. However, the participation in the SFamHC gave some families insights into the actual communication patterns in their family. For some families, the belief that they were a family that was able to communicate about everything, including cancer, was overturned. The participation in SFamHC made the families aware that their joint conversations as a whole family seldom involved emotions, but rather concerned practical issues. The participation became an eyeopener, and one son said: In fact, I think one can begin to have doubts and I think that's quite good, being able to talk about and open up for how we actually solve things. You do that through stopping to think: okay, we're very open, but do we really talk a lot to each other. . . Adult children, who were not living at home, expressed a close contact with their family, while emphasizing that they had rarely talked about their feelings or thoughts regarding their mother's illness with the other family members. It also emerged that the parents had shared 
their experiences to a greater extent with each other while the children rarely talked about what had happened. It was something of a surprise to the families that they felt that the SFamHC had been valuable and beneficial for them, and they felt that their participation in SFamHC had showed them that every family might need support like SFamHC; as one mother stated: if we hadn't participated we wouldn't have been sitting here talking about it.

\section{Timing and context matter}

While the families experienced a predominantly positive effect of participating in the SFamHC, they also experienced the timing of the SFamHC as a little bit too late in the treatment trajectory. One mother declared: It would have been even better if these conversations had come earlier, at least in my case. At the time I was so busy just surviving the days; one is sort of cooped up in one's own world. The families would have preferred for the first SFamHC to have taken place shortly after the breast cancer surgery or in connection with the start of chemotherapy treatment, when they experienced their life situation as completely overturned. Further, the families expressed that three conversations were suitable and adequate. However, some family members wanted additional conversations in order to further process insights brought forth by the SFamHC, while some children expressed that two conversations would have been enough as they felt that the third conversation was a repetition of the first two.

Being offered to participate in the SFamHC in their homes was highly appreciated by the families, since it was experienced as more relaxed, private, and safe, and as one father said: This is a safer place, ... this is our territory, so one doesn't walk away. The families expressed that they had felt some reluctance and distress before the first conversation, as they did not know if they would be able to talk openly with a stranger (the conversational leader). However, their initial unease was transformed into a more comfortable state during the 
conversations, as they felt that they as individual family members were co-creators of the SFamHC and as they got to "know" the conversational leader. Although experiencing the SFamHC as safe and permissive and feeling that the presence of the conversational leader made it possible to communicate difficult emotions and experiences, family members also expressed that they concealed certain thoughts in order not to transfer their own fear to another member in the family. One mother said: There are questions that we can discuss together but there are also questions that should have been for me alone, because I may express thoughts that transfer anxiety to my son, and I don't want that, of course. So I say or convey little in order to protect and I suppose that A, the fears he has in relation to me, we are after all mother and son. Thus, some family members expressed a desire for both individual and family conversations like SFamHC.

\section{Discussion}

Family members in the present study expressed that their participation in the SFamHC was a positive experience despite initial ambivalent feelings with regard to participating. They expressed that they got a new insight into each other's experiences and feelings through the participation in the SFamHC. They also found it soothing to tell their own story as well as listening to the other family members' narratives. Family members claimed that by participating in SFamHC they got to hear each other expressing thoughts and feelings that were not shared before and also that they themselves dared to express feelings like fear. By getting the opportunity to tell their story and disclose their experiences, the individual family members might attain an improved understanding of themselves (Ricoeur, 1992) as well as of their family members (Ricoeur, 1998), which might be healing. Thus, the participation in 
FamHC or SFamHC, and the narratives told in those conversations, may affect the healing process and also help participants reflect on their experiences.

Previous research has also shown that family members try to shield each other and experience difficulties in communicating emotions following a breast cancer diagnosis (Coyne et al., 2012; Holst-Hansson et al., 2017). The SFamHC, then, might be seen as beneficial, aimed at supporting families in finding ways of communicating their situation following a breast cancer diagnosis through relational sharing and meaningful conversation, which might strengthen their sense of being a unit and decrease their feelings of loneliness in their new and unknown life situation. However, one must bear in mind the fact that all participating families, according to their answers to the General Functioning Scale (S-GFS), perceived themselves as having a healthy family functioning, which might have affected their experience of participating in SFamHC.

All families expressed that the first SFamHC should have taken place earlier in the treatment trajectory. However, different opinions regarding the most appropriate time were expressed, which may be due to the various needs of the families in relation to the breast cancer diagnosis and different treatment regimens. Although offered routinely to every family, the timing for the initiation of supportive conversations like SFamHC should consequently be flexible and based on each family's situation, needs, and preferences. Thus, supportive conversations like SFamHC could be offered to families soon after the diagnosis, with multiple options for them to initiate the conversations later in the treatment trajectory. This is in line with the findings of a systematic review of psychosocial interventions for families with parental cancer (Inhestern et al., 2016) which emphasized the need for flexibility, accessibility, and a routine care procedure. To offer supportive interventions like SFamHC early on in the treatment trajectory is also in line with statements made by The Institute of Medicine and National Research Council, as they stress the significance of 
specific points along the cancer continuum, with particular attention given to the time for diagnosis and the end of treatment (Hewitt, Greenfield, \& Stovall, 2006). The time for diagnosis means the beginning of an emotional roller-coaster ride, while the end of active treatment is often associated with a decline of support from health care professionals. For women with breast cancer, the radiotherapy is often the end of active treatment, which could imply that an unmet need of support experienced by the families during radiation therapy might go undetected as the woman moves on to being a breast cancer survivor.

The families talked about the home as a safe and optimal place for the SFamHC, which might be due to the fact that the home is considered a place that offers a sense of safety and control (Bateson, 1972; Lindahl, Lidén, \& Lindblad, 2011; Årestedt, Benzein, Persson, \& Rämgård, 2016). Further, offering the families SFamHC in their home environment may show the family more as the unit they are, and also balance the communication between the interviewer and the family, in the sense that the nurse is a guest in the family's home (Ross \& Johansen, 2002). The point of shorter supportive conversations like SFamHC was originally to use them as routine care in the clinical setting (Bell \& Wright, 1999), but families' appreciation of having their home as a setting for the SFamHC might imply that they are less inclined to participate if the SFamHC take place at the clinic. This further points to the necessity of offering flexible interventions, as stated by Inhestern et al. (2016).

The SFamHC lasted between 15 and 40 minutes, which is similar to the findings of Svavarsdottir, Tryggvadottir and Sigurdardottir (2012) when they evaluated short-term therapeutic conversations with families following acute and chronic illness in children and adolescents. This finding indicates that the planned duration, that is, 15 minutes might not be enough for letting the family tell their narratives, or for the conversational leader to pose reflective, interventive questions, as well as giving the family members a possibility to answer. 
The appeal from some participants for both individual supportive conversations and family conversations like SFamHC, again shows the complexity in offering the right support. This further emphasizes that health care professionals should acknowledge the whole family and not focus only on the individual with breast cancer. There is a need for the perspectives of both family-related care and family-centered care, along the cancer continuum. Family-related care focuses on the individual family member, that is, the person with the illness or other family members, whereas the family is regarded as the context, while family-centered care, in contrast, focuses on the family as a unit from the perspective of several family members simultaneously (Benzein et al., 2017; Wright \& Leahey, 2013). By regarding these two as complementing each other (that is, as family-focused care) in the clinic, it is not a question of choosing the one or the other; rather, it is a matter of when to apply the family-related care and when to apply the family-centered care. Nurses and health care professionals might have to take a flexible approach and assess the unique needs of both the woman and her family members in order to provide the most appropriate care for every woman and family following a breast cancer diagnosis. Furthermore, the support should be easy to access and offered as a routine care, according to Inhestern et al. (2016).

The reflections offered by the conversational leader were experienced as central to the positive experience of the SFamHC, since the families felt that those reflections confirmed them as individuals and as a family. Moreover, the reflections of the conversational leader or of the nurses in the clinical setting may help families begin their own internal conversations, understand what has happened, and find new meaning in order to regain their ordinary life. Through their reflections, nurses also have the opportunity to acknowledge suffering and use commendations, as well as challenging families' beliefs (Limacher \& Wright, 2006; Wright \& Bell, 2009). 


\section{Methodological considerations}

Efforts were made, throughout the whole research process, to enhance trustworthiness according to the principles of Lincoln and Guba (1985). To increase the credibility of the study, all families were interviewed by the same interviewer (VV), who is a pediatric nurse with extensive experience of conducting research interviews with children as well as conversing with families. Since the study was based on a family systems approach where the entire family's experience is of interest, family interviews were performed. The strength of family interviews is that the systemic perspective, with interactions and discussions within the family, come to light. The potential weakness of family interviews is the risk of family members not daring to reveal their opinions due to mutual consideration of each other's feelings. Dependability is demonstrated by detailed descriptions of all stages in the analysis process. One possible limitation of the study is that the first author also was the conversational leader of the SFamHC. However, in order to strengthen confirmability two of the authors (AHH, VV) performed the thematic analysis and the other authors audited and confirmed the relevance of the themes. All authors were involved in the process of interpretation. Only nine families from one part of Sweden participated, which needs to be considered in terms of the generalizability of the results. Nevertheless, the findings of these elucidating interviews should contribute to a richer understanding of families' experiences of participating in SFamHC when a family member is diagnosed with breast cancer.

\section{Conclusion}

This study adds knowledge about families' experience of participating in SFamHC following a breast cancer diagnosis. It shows that a family conversation even as short as SFamHC might offer a sense of relational sharing within the family, along with a sense of 
not being alone, which may prevent feelings of isolation and vulnerability. Therefore, this study supports SFamHC as suitable for families in which a family member is diagnosed with breast cancer. We believe these results may also be transferable to families experiencing other cancer diagnoses or chronic illnesses. Future research about SFamHC should focus on the outcomes regarding family functioning and their sustainability over time. Further, there seems to be a need for offering supportive interventions on an individual level as well as on a family level.

\section{Acknowledgements}

We would like to thank the families who participated in this study. We are also grateful to the Cancer Research Foundation at the Department of Oncology Malmö University Hospital for making this study feasible through financial support. 


\section{References}

Antonovsky, A. (1996). The salutogenic model as a theory to guide health promotion. Health Promotion International, 11(1), 11-18. Doi:10.1093/heapro/11.1.11

Bateson, G. (1972). Steps to an ecology of mind: Collected essays in anthropology, psychiatry, evolution, and epistemology. Chicago, IL: University of Chicago Press.

Bell, J.M. (2015). Growing the science of Family Systems Nursing: Family health intervention research focused on illness suffering and family healing. [L'avancement de la recherche sur l'intervention infirmière systémique en santé familiale: bilan]. In F. Duhamel (Ed.), La santé et la famille: Un approche systémique en soins infirmiers [Families and health: A systemic approach in nursing care] (3 ${ }^{\text {rd }}$ ed., 102-125.) Montreal, Quebec; Canada: Gaëtan Morin editeur, Chenelière Education. [In French]. English language translation available from U of C institutional Repository, PRISM: http://hdl.handle.net/1880/51114

Belmont, J.M. (1989). Cognitive strategies and strategic learning. The socio-instructional approach. American Psychologist, 44, 142-148. Doi:10.1037/0003-066X.44.2.142

Benzein, E., Hagberg, M., \& Saveman, B.I. (2008). Being appropriately unusual - a challenge for nurses in health promoting conversations with families. Nursing Inquiry, 15(2), 106-115. Doi:10.1111/j.1440-1800.2008.00401.x 
Benzein, E. G., Hagberg, M., \& Saveman, B.I. (Eds.). (2017). Att möta familjer inom vard och omsorg [Meeting with families in health and community care]. Lund, Sweden: Studentlitteratur. [In Swedish]

Benzein, E., Olin, C., \& Persson, C. (2015). You put it all together - families' evaluation of participating in Family Health Conversations. Scandinavian Journal of Caring Sciences, 29(1), 136-44. Doi:10.1111/scs.12141

Benzein, E., \& Saveman, B-I. (2008). Health-promoting conversations about hope and suffering with couples in palliative care. International Journal of Palliative Nursing, 14(9), $439-445$.

Boyatzis, R.E. (1998). Transforming qualitative information: thematic analysis and code development. London, England: Sage.

Braun, V., \& Clarke, V. (2006). Using thematic analysis in psychology. Qualitative Research in Psychology, 3, 77-101. Doi:10.1191/1478088706qp063oa

Bylund, A., Årestedt, K., Benzein, E., \& Persson, C. (2015). Assessment of family functioning: evaluation of the General Functioning Scale in a Swedish Bariatric Sample. Scandinavian Journal of Caring Sciences, Doi:10.1111/scs.12269 
Courney, R., Puthussey, S., \& Swinglehurst, J. (2016). Couple relationships in families with dependent children after a diagnosis of maternal breast cancer in the United Kingdom: Perspectives from mothers and fathers. Journal of Psychosocial Oncology, 34(5), 413-431. Doi:10.1080/07347332.2016.1199080

Coyne, E., Wollin, J., \& Creedy, D.K. (2012). Exploration of the family's role and strengths after a young woman is diagnosed with breast cancer: Views of women and their family. European Journal of Oncology Nursing, 16, 124-130. Doi:10.1016/j.ejon.2011.04.013

Dieperink, K.B., Coyne, E., Creedy, D.K., \& Östergaard, B. (2017). Family functioning and perceived support from nurses during cancer treatment among Danish and Australian patients and their families. Journal of Clinical Nursing, 1-8. Doi:10.1111/jocn.13894

dos Santos Ribeiro Silva, M.C., Moules, N., Silva, L., \& Bousso, R.S. (2013). The 15-minute family interview: a family health strategy tool. Revista Da Escola De Enfermagem Da US P, 47(3), 634-639. Doi:10.1590/S0080-623420130000300016

Eggenberger, S.K., \& Nelms, T.P. (2007). Family interviews as a method of family research. Journal of Advanced Nursing, 58(3), 282-292. Doi:10.1111/j.1365-2648.2007.04238.x

Epstein, B.N., Bishop, S.D., \& Levin. S. (1978). The McMaster Model of Family Functioning. Journal of Marital and Family Therapy, 4(4), 19-31.

Epstein, B.N., Baldwin, M.L., \& Bishop, S.D. (1983). The McMaster Family Assessment Device. Journal of Marital and Family Therapy, 9, 171-180. 
Friedman, M.R., Bowden, V.R., \& Jones, E. (2003). Family nursing: research, theory \& practice. (5 ed.). Upper Saddle River, N.J: Prentice Hall.

Halldorsdottir, B., \& Svavarsdóttir, E.K. (2012). Purposeful Therapeutic Conversations: Are they effective for families of individuals with COPD: A quasi-experimental study. Nordic Journal of Nursing Research, 32(1), 48-51. Doi: 10.1177/010740831203200111

Hewitt, M., Greenfield, S., \& Stovall, E. (Eds.), Committee on Cancer Survivorship, Improving Care and Quality of Life, National Cancer Policy Board, Institute of Medicine, National Research Council. (2006). From Cancer Patient to Cancer Survivor: Lost in Transition. Retrieved October 10, 2017, from http://nap.edu/11468

Holst, A., Idvall, E., Bolmsjö, I., \& Wennick, A. (2017). Hoping to reach a safe haven Swedish families' lived experience when a family member is diagnosed with breast cancer. European Journal of Oncology Nursing, 31, 52-58. Doi:10.1016/j.ejon.2017.10.003

Holtslander, L. (2005). Clinical application of the 15-minute family interview: Addressing the needs of postpartum families. Journal of Family Nursing, 11(1), 5-18.

Doi: $10.1177 / 1074840709349070$

Inhestern, L., Haller, A.C., Wlodarczyk, O., \& Bergelt, C. (2016). Psychosocial Interventions for Families with Parental Cancer and Barriers and Facilitators to Implementation and Use A Systematic Review. PloS ONE, 11(6), e0156967. Doi:10.1371/journal.pone. 0156967 
John, K., Becker, K., \& Mattejat, F. (2013). Impact of family-oriented rehabilitation and prevention: an inpatient program for mothers with breast cancer and their children. PsychoOncology, 22, 2684-2692. Doi:10.1002/pon.3329

Kaakinen, J.R., \& Denham, S. (2015). Families living with chronic illness. In J.R. Kaakinen, D.P. Coehlo, R. Steele, A. Tabacco, \& S. Hanson (Eds.). Family health care nursing. Theory, practice and research. (5 ${ }^{\text {th }}$ ed.). (pp. 237-276). Philadelphia, PA: F.A. Davis.

Limacher, L. H., \& Wright, L. M. (2006). Exploring the therapeutic family intervention of commendations: Insights from research. Journal of Family Nursing, 12, 307-331. Doi: $10.1177 / 1074840706291696$

Lincoln, Y.S., \& Guba, E.G. (1985). Naturalistic Inquiry. Beverly Hills, CA: Sage Publications.

Lindahl, B., Lidén, E., \& Lindblad, B.M. (2011). A meta-synthesis describing the relationships between patients, informal caregivers and health professionals in home-care settings. Journal of Clinical Nursing, 20(3-4), 454-463. Doi:10.1111/j.13652702.2009.03008.x

Mittelmark, M. B., \& Bull, T. (2013). The salutogenic model of health in health promotion research. Global Health Promotion, 20, 30-38. Doi:10.1177/1757975913486684 
Northouse, L., Williams, A.L., Given, B., \& McCorkle, R. (2012). Psychosocial Care for Family Caregivers of Patients With Cancer. Journal of Clinical Oncology, 30, 1227-1234. Doi:10.1200/JCO.2011.39.5798

Piaget, J. (1972). Intellectual evolution from adolescence to adulthood. Human Development, 157-164. Retrieved April 10, 2017, http://www.fondationjeanpiaget.ch/fjp/site/textes/VE/JP70_Evolut_Intellect_Adoles_Adulte.p df

Ricoeur, P. (1992). Oneself as another. Chicago, IL: University of Chicago Press.

Ricoeur, P. (1998). Hermeneutics and the human sciences. Cambridge, England: Cambridge University Press.

Robbins, M.L., Mehl, M.R., Smith, H.L., \& Weihs, K.L. (2013). Linguistic indicators of patient, couple, and family adjustment following breast cancer. Psycho-Oncology, 22, 15011508. Doi:10.1002/pon.3161

Robbins, M.L., Lopez, A.M., Weihs, K.L., \& Mehl, M.R. (2014). Cancer Conversations in Context: Naturalistic Observation of Couples Coping with Breast Cancer. Journal of Family Psychology, 28(3), 380-390. Doi:10.1037/a0036458.

Ross, L., \& Johansen, C. (2002). Psychosocial home visits in cancer treatment: A qualitative study on the content of home visits. Cancer Nursing, 25, 350-357. Doi:10.1097/00002820-200210000-00003 
Ryan, C., Epstein, N.B., Keitner, G., Miller, I.W., \& Bishop, D.S. (2005). Evaluating and treating families. The McMaster Approach. New York, NY: Routledge Taylor \& Francis Group.

Stinesen Kollberg, K., Thorsteinsdottir, T., Wilderäng, U., \& Steineck, G. (2013). Worry about one's own children, psychological wellbeing, and interest in psychosocial intervention. Psycho-Oncology, 22, 2117-2123. Doi:10.1002/pon.3266.

Svavarsdottir, E.K., \& Sigurdardottir, A.O. (2013). Benefits of a Brief Therapeutic Conversation Intervention for Families of Children and Adolescents in Active Cancer Treatment. Oncology Nursing Forum, 40(5), E346-E357. Doi:10.1188/13.ONF.E346-E357

Svavarsdottir, E. K., Tryggvadottir, G. B., \& Sigurdardottir, A. O. (2012). Knowledge translation in family nursing: Does a short-term therapeutic conversation intervention benefit families of children or adolescents within a hospital setting? Findings from the Landspitali University Hospital Family Nursing Implementation Project. Journal of Family Nursing, 18(3), 303-327. Doi:10.1177/1074840712449202

Sveinbjarnardóttir, E.K., Svavarsdóttir, E.K., \& Wright, L.M. (2013). What are the benefits of a short therapeutic conversation intervention with acute psychiatric patients and their families? A controlled before and after study. International Journal of Nursing Studies, 50(5), 593-602. Doi:10.1016/j.ijnurstu.2012.10.009 
Thastum, M., Munch-Hansen, A., Wiell, A., \& Romer, G. (2006). Evaluation of a Focused Short-term Preventive Counselling Project for Families with a Parent with Cancer. Clinical Child Psychology and Psychiatry, 11(4), 529-542. Doi:10.1177/1359104506067875

World Medical Association. Declaration of Helsinki - Ethical Principles for Medical Research Involving Human Subjects. Retrieved March 03, 2018, from www.wma.net/en/30publications/10policies/b3/

Wright, L.M., \& Bell, J. (2009). Beliefs and illness. A model for healing. Calgary: $4^{\text {th }}$ Floor Press.

Wright, L. M., \& Leahey, M. (1990). Trends in the nursing of families. Journal of Advanced Nursing, 15, 148-154. Doi:10.1111/j.1365-2648.1990.tb01795.x

Wright, L.M., \& Leahey, M. (1994). Calgary Family Intervention Model: One way to think about change. Journal of Marital and Family Therapy, 20,381-395. Doi:10.1111/j.17520606.1994.tb00128.x

Wright, L.M., \& Leahey, M. (1999). Maximizing Time, Minimizing suffering: The 15-Minute (or less) Family Interview. Journal of Family Nursing, 5(3), 259-273.

Doi:10.1177/107484079900500302

Wright, L.M., \& Leahey, M. (2013). Nurses and families. A guide to family assessment and family intervention. (6th ed.). Philadelphia, PA: F.A. Davis. 
Wright, L. M., Watson, W. L., \& Bell, J. M. (1996). Beliefs: The heart of healing in families and illness. New York, NY: Basic Books.

Årestedt, 1., Benzein, E., Persson, C., \& Rämgård, M. (2016). A shared respite-The meaning of place for family well-being in families living with chronic illness, International Journal of Qualitative Studies on Health and Well-being, 11(1), 30308, Doi:10.3402/qhw.v11.30308

Östlund, U., \& Persson, C. (2014). Examining Family Responses to Family Systems Nursing Interventions: An Integrative Review. Journal of Family Nursing, 20(3), 259-286.

Doi: $10.1177 / 1074840714542962$

Östlund, U., Bäckström, B., Lindh, V., Sundin, K., \& Saveman, B.-I. (2015). Nurses’ fidelity to theory-based core components when implementing Family Health Conversations - A qualitative inquiry. Scandinavian Journal of Caring Sciences, 29, 582-590.

Doi:10.1111/scs.12179

Östlund, U., Bäckström, B., Saveman, B.I., Lindh, V., \& Sundin, K. (2016). A Family Systems Nursing Approach for Families Following a Stroke: Family Health Conversations. Journal of Family Nursing, 22(2), 148-171. Doi:10.1177/1074840716642790 



\section{Malmö University Health and Society Doctoral Dissertations}

Ross, M. W. Typing, doing and being. A study of men who have sex with men and sexuality on the Internet. 2006:1

Stoltz, P. Searching for meaning of support in nursing. A study on support in family care of frail aged persons with examples from palliative care at home. 2006:2

Gudmundsson, P. Detection of myocardial ischemia using real-time myocardial contrasts echocardiograpy. 2006:3

Holmberg, L. Communication in palliative home care, grief and bereavement. A mother's experiences. 2007:1

Ny, P. Swedish maternal health care in a multiethnic society - including the fathers. 2007:2

Schölin, T. Etnisk mångfald som organisationsidé. Chefs- och personalpraktiker i äldreomsorgen. 2008:1

Svensson, O. Interactions of mucins with biopolymers and drug delivery particles. 2008:2

Holst, M. Self-care behaviour and daily life experiences in patients with chronic heart failure. 2008:3

Bahtsevani, C. In search of evidence-based practices. Exploring factors influencing evidence based practice and implementation of clinical practice guidelines. 2008:4

Andersson, L. Endocytosis by human dendritic cells. 2009:1.

Svendsen, I. E. In vitro and in vivo studies of salivary films at solid/liquid interfaces. 2009:2.

Persson, K. Oral health in an outpatient psychiatric population. Oral status, life satisfaction and support. 2009:3.

Hellman, P. Human dendritic cells. A study of early events during pathogen recognition and antigen endocytosis. 2009:4.

Baghir-Zada, R. Illegal aliens and health (care) wants. The cases of Sweden and the Netherlands. 2009:5.

Stjernswärd, S. Designing online support for families living with depression. 2009:6.

Carlsson, A. Child injuries at home - prevention, precautions and intervention with focus on scalds. 2010:1.

Carlson, E. Sjuksköterskan som handledare. Innehåll i och förutsättningar för sjuksköterskors handledande funktion i verksamhetsförlagd utbildning - en etnografisk studie. 2010:2.

Sinkiewicz, G. Lactobacillus reuteri in health and disease. 2010:3.

Tuvesson, H. Psychiatric nursing staff and the workplace. Perceptions of the ward atmosphere, psychosocial work environment, and stress. 2011:1.

Ingvarsdotter, K. Mental ill health and diversity. Researching human suffering and resilience in a multicultural context. 2011:2.

Hamit-Eminovski, J. Interactions of biopolymers and metal complexes at biological interfaces. 2011:3. 
Mellgren, C. What's neighbourhood got to do with it? The influence of neighbourhood context on crime and reactions to crime. 2011:4.

Annersten Gershater, M. Prevention of foot ulcers in patients with diabetes mellitus. Nursing in outpatient settings. 2011:5.

Pooremamali P. Culture, occupation and occupational therapy in a mental care context- the challenge of meeting the needs of Middle Eastern immigrants. 2012:1

Gustafsson A. Aspects on sepsis: treatment and markers. 2012:2

Lavant, E. Multiplex HLA-DR-DQ genotyping. For genetic epidemiology and clinical risk assessment. 2012:3

Wangel, A-M. Mental ill-health in childbearing women. Markers and risk factors. 2012:4

Scaramuzzino, R. Equal opportunities? - A cross-national comparison of immigrant organisations in Sweden and Italy. 2012:5

Ivert, A-K. Adolescent mental health and utilisation of psychiatric care - The role of parental country of birth and neighbourhood of residence 2013:1

Znamenskaya, Y. Effect of hydration on thermodynamic, rheological and structural properties of mucin. 2013:2

Andersson, F. The female offender. Patterning of antisocial and criminal activity over the lifecourse. 2013:3

Lindroth, M. Utsatthet och sexuell hälsa - en studie om unga på statliga ungdomshem. 2013:4

Hulusjö, A. The multiplicities of prostitution experience - narratives about power and resistance. 2013:5

Falk, M. Direct electron transfer based biofuel cells. Operation in vitro and in vivo. 2014:1

Finnbogadóttir, H. Exposure to domestic violence during pregnancy. Impact on outcome, midwives' awareness, women's experience and prevalence in the south of Sweden. 2014:2

Fagerström, A. Effects of surfactant adjuvants on barrier properties of plant leaf cuticle. 2014:3

Lamberg, P. Design and characterization of direct electron transfer based biofuel cells including tests in cell cultures. 2014:4

Richert, T. Överdoser, försörjningsstrategier och riskhantering - livsvillkor för personer som injicerar narkotika. 2014:5

Örmon, K. Experiences of abuse during the life course. - Disclosure and the care provided among women in a general psychiatric context. 2014:6

Sjöblom, I. Planerade hemförlossningar i Norden - kvinnors och barnmorskors perspektiv. 2014:7

Albèr, C. Humectants and Skin - Effects of hydration from molecule to man. 2015:1

Kisch M., A. Allogeneic stem cell transplantation. - Patients' and sibling donors' perspectives. 2015:2

Weiber, I. Children in families where the mother has an intellectual or developmental disability - incidence, support and first person perspectives. 2015:3 
Schlyter, M. Myocardial infarction, Personality factors, Coping strategies, Depression and Secondary prevention 2016:1

Carlström, C. BDSM - Paradoxernas praktiker. 2016:2

El-Schich, Z. Novel imaging technology and tools for biomarker detection in cancer. 2016:3

Boonsatean, W. Living with type 2 diabetes in Thai population: Experiences and socioeconomic characteristics. 2016:4

Vejzovic, V. Going through a colonoscopy and living with inflammatory bowel disease: Children's and parents' experiences and evaluation of the bowel cleansing quality prior to colonoscopy. 2016:5

Isma, G.E. Overweight and obesity in young children: Preventive work in child health care with focus on nurses' perceptions and parental risk factors. 2016:6

Brännvall, M. Frigörelse med förhinder - Om polisanmälan när kvinnor tar sig ur mäns våld i nära relationer. 2016:7

Pankratov, D. Self-charging biosupercapacitors. 2016:8

Guidi, P. Social work assessment of families with children at risk: Similarities and differences in Italian and Swedish public social services. 2016:9

Jakobsson, J. The process of recovery after colorectal cancer surgery: Patients' experiences and factors of influence. 2017:1

Gerell, M. Neighborhoods without community. Collective efficacy and crime in Malmö, Sweden. 2017:2

Wierzbicka, C. New fractionation tools targeting elusive post-translational modifications. 2017:3

Afzelius, M. Families with parental mental illness: Supporting children in psychiatric and social services. 2017:4

Nordgren, J. Making drugs ethnic - Khat and minority drug use in Sweden. 2017:5

Nilsson, E-L. Parental socialization and adolescent offending. 2017:6

Sixtensson, J. Härifrån till framtiden. Om gränslinjer, aktörskap och motstånd i tjejers vardagsliv. 2018:1

Vasiljevic, Z. Ambulatory risk assessment and intervention in the prison services. Using Interactive Voice Response to assess and intervene on acute dynamic risk among prisoners on parole. 2018:2

González Arribas, E. Flexible and transparent biological electric power sources based on nanostructured electrodes. 2018:3

Svalin, K. Risk assessment of intimate partner violence in a police setting. Reliability and predictive accuracy. 2018:4

Andersson, M. Hate crime victimization: consequences and interpretations. Consequences and interpretations. 2018:5

Djampour, P. Borders crossing bodies. The stories of eight youth with experience of migrating. 2018:6 
Yeung, S.Y. Stimuli-responsive lipid bilayer mimics for protein, virus and cell recognition. 2018:7

Holst-Hansson, A. On a journey for survival: everyday life during radiation therapy from the perspectives of women with breast cancer and their families. 2018:8

The publications are available online.

See www.mah.se/muep 

